\title{
IntechOpen
}

\section{Meat Science and Nutrition}

Edited by Muhammad Sajid Arshad 

MEAT SCIENCE AND NUTRITION

Edited by Muhammad Sajid Arshad 


\section{Meat Science and Nutrition}

http://dx.doi.org/10.5772/intechopen.71954

Edited by Muhammad Sajid Arshad

\section{Contributors}

Muhammad Sajid Arshad, Aftab Ahmed, Ali Imran, Shinawar Waseem Ali, Angelica S. C. Pereira, Taiane Martins, Julian Muñoz, Gabriela Moura, Adrielle Ferrinho, Ingrid Fuzikawa, Lenise Mueller, Tamyres Amorim, Jéssica Gemelli, Fernando Baldi, Marcos Lemos, Akbar Taghizadeh, Jamal Seifdavati, Rabia Shabir Ahmad, Muhammad Bilal Hussain

\section{(c) The Editor(s) and the Author(s) 2018}

The rights of the editor(s) and the author(s) have been asserted in accordance with the Copyright, Designs and Patents Act 1988. All rights to the book as a whole are reserved by INTECHOPEN LIMITED. The book as a whole (compilation) cannot be reproduced, distributed or used for commercial or non-commercial purposes without INTECHOPEN LIMITED's written permission. Enquiries concerning the use of the book should be directed to INTECHOPEN LIMITED rights and permissions department (permissions@intechopen.com). Violations are liable to prosecution under the governing Copyright Law.

\section{(cc) BY}

Individual chapters of this publication are distributed under the terms of the Creative Commons Attribution 3.0 Unported License which permits commercial use, distribution and reproduction of the individual chapters, provided the original author(s) and source publication are appropriately acknowledged. If so indicated, certain images may not be included under the Creative Commons license. In such cases users will need to obtain permission from the license holder to reproduce the material. More details and guidelines concerning content reuse and adaptation can be foundat http://www.intechopen.com/copyright-policy.html.

\section{Notice}

Statements and opinions expressed in the chapters are these of the individual contributors and not necessarily those of the editors or publisher. No responsibility is accepted for the accuracy of information contained in the published chapters. The publisher assumes no responsibility for any damage or injury to persons or property arising out of the use of any materials, instructions, methods or ideas contained in the book.

First published in London, United Kingdom, 2018 by IntechOpen eBook (PDF) Published by IntechOpen, 2019 IntechOpen is the global imprint of INTECHOPEN LIMITED, registered in England and Wales, registration number: 11086078, The Shard, 25th floor, 32 London Bridge Street

London, SE19SG - United Kingdom

Printed in Croatia

British Library Cataloguing-in-Publication Data

A catalogue record for this book is available from the British Library

Additional hard and PDF copies can be obtained from orders@intechopen.com

Meat Science and Nutrition

Edited by Muhammad Sajid Arshad

p. cm.

Print ISBN 978-1-78984-233-3

Online ISBN 978-1-78984-234-0

eBook (PDF) ISBN 978-1-83881-633-9 


\section{We are IntechOpen, \\ the world's leading publisher of Open Access books}

Built by scientists, for scientists

\section{$3,800+$}

Open access books available

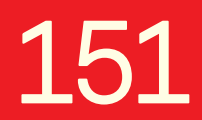

Countries delivered to

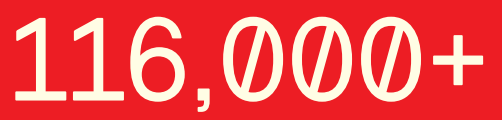

International authors and editors
$120 \mathrm{M}+$

Downloads

Our authors are among the

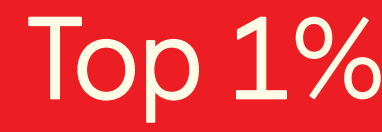

most cited scientists

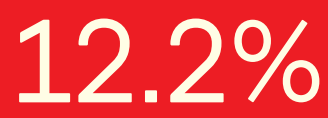

Contributors from top 500 universities

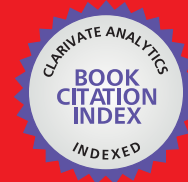

WEB OF SCIENCE ${ }^{\mathrm{TM}}$

Selection of our books indexed in the Book Citation Index in Web of Science ${ }^{\mathrm{TM}}$ Core Collection (BKCI)

Interested in publishing with us?

Contact book.department@intechopen.com

Numbers displayed above are based on latest data collected.

For more information visit www.intechopen.com

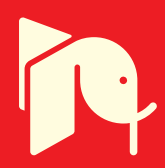





\section{Meet the editor}

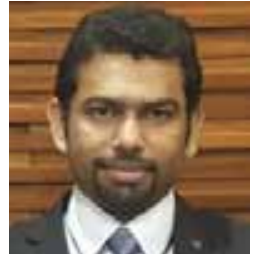

Dr. Muhammad Sajid Arshad is currently working as an assistant professor at the Institute of Home and Food Sciences, Government College University, Faisalabad, Pakistan. He served as a visiting research scholar at the University of Illinois, Urbana Champaign, USA, for a period of six months. He received his doctoral degree from the University of Agriculture, Faisalabad, Pakistan, in 2013. From 2016 to 2017, he worked as a postdoctoral researcher at Kyungpook National University, South Korea. Dr. Arshad is the author of about 40 publications and has five book chapters to his credit. His area of research is food science, particularly meat science and halal foods. 



\section{Contents}

Section 1 Introduction to Meat Science and Nutrition 1

Chapter 1 Introductory Chapter: Meat Science and Human Nutrition 3 Aftab Ahmed, Muhammad Sajid Arshad, Ali Imran and Shinawar Waseem Ali

Section 2 Composition of Meat with Reference to Fatty Acids 15

Chapter 2 Fat Deposition, Fatty Acid Composition, and Its Relationship with Meat Quality and Human Health 17

Taiane da Silva Martins, Marcos Vinícius Antunes de Lemos, Lenise Freitas Mueller, Fernando Baldi, Tamyres Rodrigues de Amorim, Adrielle Matias Ferrinho, Julian Andres Muñoz, Ingrid Harumi de Souza Fuzikawa, Gabriella Vespe de Moura, Jéssica Luana Gemelli and Angélica Simone Cravo Pereira

Section 3 Strategies to Improve Meat Quality 39

Chapter 3 New Nutritional Strategies for Improving the Quality of Meat 41

Akbar Taghizadeh and Jamal Seifdavati

Section 4 Nutritional Composition of Meat 59

Chapter 4 Nutritional Composition of Meat 61

Rabia Shabir Ahmad, Ali Imran and Muhammad Bilal Hussain 

Section 1

Introduction to Meat Science and Nutrition 



\title{
Chapter 1
}

\section{Introductory Chapter: Meat Science and Human Nutrition}

\author{
Aftab Ahmed, Muhammad Sajid Arshad, \\ Ali Imran and Shinawar Waseem Ali \\ Additional information is available at the end of the chapter
}

http://dx.doi.org/10.5772/intechopen.81001

\section{Introduction}

Meat holds a pivotal position among most of the communities. Meat is viewed as a sustenance of high nutritive incentive as its protein has $70 \%$ of biological availability in the body, and therefore it is frequently seen as the main food while planning meals. It is comparatively a good source of metabolically active iron and furthermore enhances its absorption from other food sources, its amino acid composition supplements the nutrition of many plant foods, and it is a concerted supply of vitamin $B$ complex, including vitamin $B_{12}$, which is not present in plant foods. Therefore, meat and meat products are preferred to fulfill protein requirements [1].

\section{Meat as a source of protein}

Human prerequisites for protein have been altogether researched throughout the years and are assessed to be $55 \mathrm{~g}$ for each day for a grown-up male and $45 \mathrm{~g}$ for female. There is a higher need in different malady states and states of strain. These quantities allude to protein of what is named "good quality" and exceedingly palatable; generally, the sum ingested must be expanded proportionately to recompense for poor quality and lower palatability [2]. Generally, the muscle comprises of around 75\% water, $20 \%$ protein, and 3\% fat. Proteins are the real segment of the dry matter of lean meat. Nine of the amino acids in proteins are basic (or semi-fundamental) in light of the fact that the human body is unable to produce them and thus should be taken up in diet [1]. Consequently, the prerequisite for dietary protein comprises of two segments: (a) necessity for the nutritiously basic amino acids and (b) the need to meet the prerequisite for non-particular nitrogen keeping in mind the end goal to supply 
the nitrogen fundamental for the supply of the healthy nonessential amino acids and other physiologically essential nitrogen-containing chemical compounds (nucleic acids, creatine, and porphyrins). Proteins are separated into their constituent amino acids in a process called digestion, which are then consumed and utilized for the biosynthesis of endogenous proteins [2]. These are fundamental for the human body in different capacities with respect to the development and repairing of the tissues, for the correct elements of the antibodies and for the control of catalysts and hormones [3]. There exists a tremendous variation in amino acid profile among different food sources, and it depends upon the unique mechanism of protein synthesis. The nutrition-delivering attribute of a protein depends upon the capacity of satisfying the human body needs [4]. Low-quality dietary proteins demonstrate an imbalanced proportion of fundamental amino acids; the most missing is known as the limiting amino acid [5]. The amino acid arrangement of meat protein is generally consistent paying little heed to the cut or organ from which the meat is procured. An outstanding exemption is for meats containing a lot of connective tissue, due to the unique amino acid profile of collagen and elastin. Meat contains mostly elevated amounts of the key essential amino acids, lysine, threonine, and tryptophan, and sulfur-containing amino acids (methionine, cysteine, homocysteine, and taurine) [6]. Protein quality is typically characterized by the amino acid profile of egg protein, which is viewed as a standard. It isn't amazing that animal proteins, for example, meat, milk, and cheese, have a tendency to be of a higher protein quality than plant proteins. Animal proteins have a superior palatability (95\%) contrasted with plant proteins (80-90\%) [7]. The lower digestibility of plant proteins is due to the fact that plant proteins are always present enclosed in a polysaccharide network that resists the proteolytic enzymes to interact with the food protein. A solid nourishment requires an adjusted blend of various sustenance proteins. By consolidating plant and animal sustenance, the dietary nature of the protein can be expanded on account of the supplementing impact [8].

\section{Fat}

Fat is the wealthiest dietary wellspring of vitality and supplies basic nutrients, for example, basic unsaturated fats, and in addition precursors of other nutrients that control various physiological processes (e.g., prostaglandins) and retain fat-based vitamins (A, D, E, and K) [9]. Additionally, fat has a conclusive significance as the most dense energy source for the body, as obsession and also a security of the organs and as wellspring of unsaturated fats which again go about as auxiliary component of cell films [10]. Fat additionally gives acceptability and flavor to nourishment. In the correct extents, it is subsequently a basic segment of any adjusted eating regimen, and consequently the level of fat decrease must not just consider tactile or mechanical factors yet it should likewise be, for example, to keep away from loss of wholesome advantages [11]. Meat is taken a gander at basically in light of its fat substance being for the most part included under the heading of fatty nourishments [12]. The fat in animals is principally found in their fatty tissue and is recognized as terminal fat (to a great extent, subcutaneous fatty tissue), intermuscular and intramuscular fat [13]. The remainder of these is called marbling. The measure of intermuscular and terminal fat present in a meat cut shifts, contingent upon the fat discharge of the animal and how the cut has been trimmed. As opposed to the far-reaching conviction that animal fat is for the most part made out of 
saturated fatty acids (SFA), generally $50 \%$ of the fatty acids in meat are unsaturated. Meat lipids more often than not contain under $50 \%$ SFA and up to $70 \%$ (hamburger $50-52 \%$, pork $55-57 \%$, sheep $50-52 \%$, and chicken $70 \%$ ) unsaturated fats. Meat unsaturated fat synthesis is impacted by hereditary elements, in spite of the fact that to a lower degree than dietary components [14]. The level of heftiness likewise affects the meat unsaturated fat synthesis. The substance of saturated and monounsaturated unsaturated fatty acids (MUFA) increments speedier with expanding largeness than does the substance of polyunsaturated unsaturated fatty acids (PUFA), bringing about a decline in the relative extent of PUFA and therefore in the polyunsaturated/saturated fatty acid (P/S) proportion [15]. The impact of largeness on the $\mathrm{P} / \mathrm{S}$ proportion can be disclosed to a substantial degree by contrasts in the fatty acids arrangement of the real lipid portions and the relative commitment of these parts to add up to lipids [16]. Muscle lipids are made out of polar lipids, basically phospholipids situated in the phone layers, and impartial lipids comprising essentially of triacylglycerols in the adipocytes that are situated along the muscle filaments and in the interfascicular zone [17]. A little measure of triacylglycerols is additionally present as cytosolic beads in the muscle strands. The substance of phospholipids in the muscle is moderately autonomous of the aggregate fat substance and differs in the vicinity of 0.2 and $1 \%$ of muscle weight. Be that as it may, the substance of muscle triacylglycerols is emphatically identified with the aggregate fat substance and differs from 0.2 to more than 5\% [18]. Phospholipids are especially rich in PUFA, though triacylglycerols contain bring-down measures of PUFA [8]. Since phospholipids are layer parts, their extent of SFA to unsaturated fats is entirely controlled so as to keep up film properties. Despite the fact that the PUFA substance of triacylglyerols can be impacted by dietary elements, especially in monogastrics, it is weakened once more by fatty acid union comprising of SFA and MUFA, accordingly, causing a decrease in the P/S proportion with expanding fat testimony [19]. The most omnipresent fatty acids in meat are oleic (C18:1), palmitic (C16:0), and stearic (C18:0) acid. Linoleic acid (C18:2n-6) is the transcendent PUFA $(0.5-7 \%)$, trailed by alpha-linolenic acid (C18:3n-3). Trans-fatty acids involve beneath $0.5 \%$ of aggregate fatty acids over a wide range of meat from monogastric animals; in ruminant meats they speak to around 2-4\% [20]. The biggest piece of soaked, monounsaturated, and polyunsaturated fatty acids are provided by the eating routine and however can likewise be incorporated in the body with exemption of the n-3 and n-6 fatty acids [21]. Thusly, these two gatherings of PUFAs are essential and must be provided by the sustenance. Meat can add to the supply with physiologically essential long-chain polyunsaturated n-3 fatty acids (LC n-3 PUFA), i.e., eicosapentaenoic acid (EPA), docosapentaenoic acid (DPA), and docosahexaenoic acid (DHA), which appeared to apply different valuable well-being impacts, in light of the fact that meat is much more regularly devoured than fish [22]. Because of the extremely restricted in vivo combination of EPA and DHA from dietary alpha-linolenic acid in grown-up people, animals can be viewed as a transformer of alpha-linolenic acid to EPA and DHA through their amalgamation and following stockpiling in their muscles [23]. EPA and DHA are principally consolidated into muscle tissue phospholipids. In this way, lean meat should be considered when dietary LC n-3 PUFA admissions are resolved [24]. Fatty fish and fish are known to be a rich wellspring of the LC n-3 PUFA, bringing about general well-being proposals for consistent utilization of fatty fish [25]. Be that as it may, fatty fish has its negative perspectives too. Harmful mixes, for example, fat-dissolvable methyl mercury, dioxins, and polychlorinated biphenyls, are found in fatty fish. Moreover, the world's seas are intensively fished, abandoning a few species in peril of termination [26]. Hence elective nourishment sources are being 
produced, empowered by the presentation of nutritious and well-being claims for utilitarian sustenance rich in LC n-3 PUFA [27]. These comprise of processed foods enriched with LC n-3 PUFA from microalgal and different sources and meat, milk and eggs from domesticated animals bolstered n-3-rich weight control plans. Advance improvement of meat with the LC n-3 PUFA might be a functional other option to expand the utilization of fish as a method for expanding populace admissions of LC n-3 PUFA [28].

\section{Meat vitamins}

Vitamins are a mind-boggling gathering of natural intensifiers that are by and large present in little amounts in foodstuffs [29]. Vitamins are critical as cofactors in enzymatic procedures and furthermore have hormonal role. Generally, vitamins have been characterized based on their dissolvability in either lipid or fluid solvents, and they are along these lines comprehensively isolated into fat- and water-dissolvable vitamin classifications [30]. Fat-solvent vitamins have a tendency for the most part to be reserved in the liver and fat tissues of animals, in relationship with reserved fat, and they are not promptly discharged [31]. Water-solvent vitamins, then again, have a tendency to be deposited to a far lesser degree in the body. The vitamins contained in animal and human eating methodologies are prevalently gotten from either plant or microbial source. Animal cells keep up the capacity for a new combination of a few vitamins, for example, vitamin D and, contingent upon the species included, niacin and ascorbate and additionally the capacity to change over forerunners (provitamins) to their dynamic frame. Moreover, commensal microorganisms in both the ruminant and nonruminant stomach-related tract can fill in as wellspring of vitamins, for example, vitamin $\mathrm{K}$ and the water-dissolvable B-complex vitamins [32]. Meat has for some time been perceived as a decent wellspring of B vitamins for human nourishment. Vitamin B6 exists in six structures: pyridoxal (PL), pyridoxine (PN), pyridoxamine (PM), and their phosphate subordinates: pyridoxal 5'-phosphate (PLP), pyridoxine 5'-phosphate (PNP), and pyridoxamine 5'-phosphate (PMP) [33]. PLP is the dynamic coenzyme shape and is the most essential frame in human digestion. It assumes a key part in the capacity of roughly 100 compounds that catalyze basic synthetic responses in the human body [34]. For instance, PLP works as a coenzyme for glycogen phosphorylase, a chemical that catalyzes the arrival of glucose put away in the muscle as glycogen [8]. A significant part of the PLP in the human body is found in the muscle bound to glycogen phosphorylase [35]. PLP is additionally a coenzyme for responses used to create glucose from amino acids, a procedure known as gluconeogenesis. Vitamin B1, otherwise called thiamine, is basic for ordinary cell capacities, development, and advancement. Thiamine in its coenzyme frame, thiamine diphosphate, assumes an urgent part in typical starch digestion, in which it takes part in the decarboxylation of pyruvic and $\alpha$-ketoglutaric acids and in the usage of pentose in the hexose monophosphate pathway [36]. People and different well-evolved animals can't make thiamine and along these lines must acquire the vitamin from exogenous sources by means of intestinal retention [12]. Meat has been perceived as a decent wellspring of thiamine. Vitamin B2, generally named riboflavin, is an antecedent of flavin mononucleotide (FMN) and flavin adenine dinucleotide (FAD). FMN and FAD are coenzymes for various oxidases and dehydrogenases in eukaryotic cells. Vitamin B12 is the biggest and most complex of the considerable number of vitamins [37]. The structure of B12 depends on a corrin 
ring, which is like the porphyrin ring found in heme, chlorophyll, and cytochrome. The focal metal particle is cobalt $\left(\mathrm{Co}^{2+}\right)$. Hence, cobalamin is the term used to allude to mixes having B12 action [38]. Methylcobalamin and 5-deoxyadenosyl cobalamin are the types of vitamin B12 utilized as a part of the human digestion. Vitamin B12 is particularly synthesized by microorganisms or by consolidation of some microbial constituents into nourishments. In ruminants, vitamin B12 is synthesized inside the rumen and consumed through the stomach-related tract preceding being transported by means of blood to body tissues. Ruminant items (meat and milk) constitute the significant normal wellspring of vitamin B12 for people [13]. Niacin is an essential component of coenzymes NAD and NADP, which act as a hydrogen donor or electron acceptor and required by approximately 200 enzymes primarily dehydrogenases. Pantothenic acid functions in the body as a component of CoA and 4'-phosphopantetheine [39]. Biotin functions in cells by covalently binding with enzymes and thus is considered as coenzyme. In addition, biotin functions in non-coenzyme roles including possible roles in cell proliferation and gene expression. Folate is involved in the metabolism of several amino acids, including histidine, serine, glycine, and methionine [11].

\section{Minerals and trace elements}

Meat also contains minerals and vitamins in addition to other nutrients like protein and fat. They are considered an essential part of diet as the body is unable to synthesize them, and they are involved in important life-sustaining metabolic pathways [1]. The most abundantly found minerals in meat are discussed below.

\subsection{Iron}

The quantity of iron consumed from the daily food intake relies upon an array of factors including its compound structure, the concurrent presence of other food components that can upregulate or downregulate its absorption, and different physiological variables of the individual including iron status. In general, while setting recommended daily intake of nutrients, the extent of iron ingested from a blended daily intake is normally taken as $10 \%$. Half of the iron in meat is available as heme iron (in hemoglobin) [40]. Both heme iron and non-heme iron (inorganic iron) are abundantly found in meat; moreover, iron absorption-reducing factors (phytate, tannins, oxalate, and fibers) are also found missing in meat. The bioavailability of iron in the body is approximately $1-10 \%$ from non-heme, while heme iron contributes $20-25 \%$ in iron absorption. The iron absorbed from meat source does not only have increased absorption in the human body but also helps in the proper absorption of iron from other sources; therefore, the intake of meat is recommended along other sources to prevent the occurrence of anemia [7].

Besides, the admission of meat tissue is known to improve the retention of non-heme and heme iron, the supposed "meat factor." The meat factor has not yet been distinguished but rather in a few examinations has been credited to cysteine or cysteine-containing peptides [41]. The possibility of cysteine and cysteine-containing peptides as the meat factor was additionally researched by others with the real discoveries that salt-dissolvable meat protein extricates containing for the most part myofibrillar proteins showed upgraded in vitro iron dialyzability [42]. Proposed, in the light of scientific explorations, it has been 
observed that iron-binding peptides are created by pepsin processing and tie iron in a dissolvable frame in the stomach, anticipating connection with assimilation inhibitors, for example, phytic acid and polyphenols [14]. An eating regimen which is principally made out of vegetables, rice, beans, and corn is related with a poor iron bioavailability which in any event clarifies the high occurrence of weakness in under developed nations. Meat iron functions in the body as part of several proteins, including serving as a cofactor for dozens of enzymes. In many body proteins, iron is present as part of heme [43]. In other proteins, iron is found in a cluster with sulfur (2Fe-2S, $4 \mathrm{Fe}-4 \mathrm{~S}$, or $3 \mathrm{Fe}-4 \mathrm{~S})$, by itself as a single atom or as part of a bridge with oxygen. Heme proteins represent the largest group and include hemoglobin, myoglobin, and cytochromes involved in electron transport and enzymes such as monooxygenases, dioxygenases, and oxidases [44]. Iron-sulfur proteins also include several enzymes involved in electron transport, as well as a few non-redox enzymes such as aconitase and ferrochelatase. Proteins that contain single iron atoms are mostly mono- and dioxygenase enzymes, and the one iron-oxygen bridge protein also is an enzyme, ribonucleotide reductase [15].

\subsection{Copper}

The essentiality of copper is due, in part, to its participation as an enzyme cofactor and as an allosteric component of enzymes. Superoxide dismutase (SOD) is copper- and zinc-dependent and is found in the cytosol of most cells of the body [45]. The phospholipid components of cells are extensively damaged by superoxide radicals. In other words, without SOD, superoxide radicals can form more destructive hydroxyl radicals that can damage unsaturated double bonds in cell membranes, fatty acids, and other molecules in cells. SOD therefore assumes a very important protective function. Cytochrome c oxidase contains three copper atoms per molecule [46]. One subunit of the enzyme contains two copper atoms and functions in electron transfer. Amine oxidases are also copper dependent. The oxidation of biogenic amines like tyramine, histamine, and dopamine into aldehydes and ammonium ions is catalyzed by amine oxidases, found both in the blood and in body tissues [47].

\subsection{Zinc}

Meat is the wealthiest wellspring of zinc in the eating routine and supplies 33\% to one portion of the aggregate zinc admission of meat-eaters. It is notable that ingestion of dietary zinc from animal protein-based suppers is higher contrasted with whole grain-based dinners [48]. The fundamental reason is, as depicted for iron, the nonattendance of zinc ingestion hindering elements like phytate and filaments. It has been demonstrated that meat protein upgrades zinc retention from phytate-containing suppers because of its liking for zinc contrasted with phytate [49].

Zinc is present in all tissues of the body and is a component of more than 50 enzymes. Carbonic anhydrase, found primarily in the erythrocytes and in the renal tubule, is essential for respiration. Alkaline phosphatase contains four zinc atoms per enzyme molecule [50]. The enzyme, found mainly in the bone and in the liver (with small amounts in the plasma). Alcohol dehydrogenase also contains four zinc ions per enzyme molecule, with two of the four required 
for catalytic activity and two required for structural purposes (protein conformation). This enzyme is important in the conversion of alcohols to aldehydes (e.g., retinol to retinal, which is needed for the visual cycle and night vision) [51]. Carboxypeptidase A, an exopeptidase secreted by the pancreas into the duodenum, is necessary to digest proteins. Aminopeptidase is also involved in protein digestion. Aminopeptidases contain one zinc atom, needed for catalytic activity. The enzyme cleaves amino acids from the amino terminal end of the protein or polypeptide that is being digested in the intestinal tract. Superoxide dismutase (SOD) found in the cell cytoplasm requires two atoms each of zinc and copper for function; zinc appears to have a structural role in the enzyme [52].

\subsection{Manganese}

Meat is a rich source of metabolically active manganese. At the molecular level, manganese, like other trace elements, can function both as an enzyme activator and as a constituent of metalloenzymes. Many transferases require manganese [53]. Two examples are xylosyl transferases and glycosyl (or called galactosyl) transferases. Glycosyl transferases catalyze the transfer of a sugar moiety such as galactose from uridine diphosphate (UDP) to an acceptor molecule. Manganese also activates prolidase, a dipeptidase with specificity for dipeptides [14]. The final step of collagen degradation is catalyzed by prolidase found in dermal fibroblasts. Arginase, which requires four manganese atoms per molecule, is a cytosolic enzyme responsible for urea formation and found in high concentrations in the liver [54]. The $\mathrm{Mn}^{2+}$ may allosterically activate arginase through a $\mathrm{pH}$-mediated role. Low-manganese diets in animals have been shown to decrease arginase activity. Phosphoenolpyruvate carboxykinase (PEPCK), also activated by manganese, converts oxaloacetate to phosphoenolpyruvate and carbon dioxide. This reaction is important in gluconeogenesis [55]. The activity of phosphoenolpyruvate carboxykinase decreases in animals with manganese deficiency. Pyruvate carboxylase, which contains four manganese atoms, converts pyruvate to oxaloacetate, a TCA cycle intermediate [56].

\subsection{Selenium}

The trace component selenium (Se) is a significant supplement for human well-being. It is a part of various imperative selenoproteins including compounds required for such capacities as antioxidative guard, lessening of aggravation, thyroid hormone creation, DNA production, and proliferation [57]. It can likewise be changed over in the body to Se metabolites that are thought to decrease the blood supply to tumors and destroy malignancy cells [58]. The animals raised utilizing low-Se feedstuff store generally low centralizations of the mineral in their tissues and consumable items (e.g., milk, eggs), while animals nourished with a moderately high-Se eating routine yield sustenance items with substantially higher Se fixations. On account of the requirements of domesticated animals for Se to avoid crippling inadequacy disorders, Se (typically as $\mathrm{Na}_{2} \mathrm{SeO}_{3}$ ) is regularly utilized as a sustain supplement in animal nourishment in numerous parts of the world. This strategy has momentously decreased the incidents of selenium deficiencies in North America and Europe during the last 25 years [59]. 


\section{Author details}

Aftab Ahmed ${ }^{1}$, Muhammad Sajid Arshad ${ }^{1 *}$, Ali $\operatorname{Imran}^{1}$ and Shinawar Waseem Ali $^{2}$

*Address all correspondence to: sajid_ft@yahoo.com

1 Institute of Home and Food Sciences, Government College University, Faisalabad, Pakistan

2 Institute of Agricultural Sciences, University of the Punjab, Lahore, Pakistan

\section{References}

[1] McCance RA, Widdowson's EM. The Composition of Foods. 6th ed. Cambridge; UK: Royal Society of Chemistry; 2002

[2] Abete I, Romaguera D, Vieira AR, Lopez de Munain A, Norat T. Association between total, processed, red and white meat consumption and all-cause, CVD and IHD mortality: A meta-analysis of cohort studies. The British Journal of Nutrition. 2014;112:762-775

[3] Afshin A, Micha R, Khatibzadeh S, Mozaffarian D. Consumption of nuts and legumes and risk of incident ischemic heart disease, stroke, and diabetes: A systematic review and meta-analysis. The American Journal of Clinical Nutrition. 2014;100:278-288

[4] Alexander DD, Weed DL, Miller PE, Mohamed MA. Red meat and colorectal cancer: A quantitative update on the state of the epidemiologic science. Journal of the American College of Nutrition. 2015;34(6):521-543. DOI: 10.1080/07315724.2014.992553

[5] Aaslyng MD, Duedahl-Olesen L, Jensen K, Meinert L. Content of heterocyclic amines and polycyclic aromatic hydrocarbons in pork, beef and chicken barbecued at home by Danish consumers. Meat Science. 2013;93:85-91

[6] Bellavia A, Larsson SC, Bottai M, Wolk A, Orsini N. Differences in survival associated with processed and with nonprocessed red meat consumption. The American Journal of Clinical Nutrition. 2014;100:924-929

[7] Berger S, Raman G, Vishwanathan R, Jacques PF, Johnson EJ. Dietary cholesterol and cardiovascular disease: A systematic review and meta-analysis. The American Journal of Clinical Nutrition. 2015;102:276-294

[8] Bouvard V, Loomis D, Guyton KZ, Grosse Y, Ghissassi FE, Benbrahim-Tallaa L, et al. Carcinogenicity of consumption of red and processed meat. The Lancet Oncology. Dec 2015;16(16):1599-1600. DOI: 10.1016/S1470-2045(15)00444-1

[9] Elango R, Ball RO, Pencharz PB. Amino acid requirements in humans: With a special emphasis on the metabolic availability of amino acids. Amino Acids. 2009;37:19-27 
[10] Cassens RG, Briskey EJ, Hoekstra WG. Variation in zinc content and other properties of various porcine muscles. Journal of the Science of Food and Agriculture. 1963;14:427-432

[11] MontagneseC, Santarpia L, Buonifacio M, Nardelli A, Caldara AR, Silvestri E, etal. European food-based dietary guidelines: A comparison and update. Nutrition. 2015;31:908-915

[12] O'Sullivan TA, Hafekost K, Mitrou F, Lawrence D. Food sources of saturated fat and the association with mortality: A meta-analysis. American Journal of Public Health. 2013; 103:e31-e42

[13] Rouhani MH, Salehi-Abargouei A, Surkan PJ, Azadbakht L. Is there a relationship between red or processed meat intake and obesity? A systematic review and meta-analysis of observational studies. Obesity Reviews. 2014;15:740-748

[14] Wyness L, Weichselbaum E, O'Connor A, Williams EB, Benelam B, Riley H, et al. Red meat in the diet: An update. Nutrition Bulletin. 2011;36:34-77

[15] Wood JD, Richardson RI, Nute GR, Fisher AV, Campo MM, Kasapidou E, et al. Effects of fatty acids on meat quality: A review. Meat Science. 2003;66:21-32

[16] Williamson CS, Foster RK, Stanner SA, Buttriss JL. Red meat in the diet. Nutrition Bulletin. 2005;30:323-355

[17] Moeller A, MacNeil SD, Ambrose RF, Que Hee SS. Elements in fish of Malibu Creek and Malibu Lagoon near Los Angeles, California. Marine Pollution Bulletin. 2003;46:424-429

[18] Piironen V, Toivo J, Lampi AM. New data for cholesterol contents in meat, fish, milk, eggs and their products consumed in Finland. Journal of Food Composition and Analysis. 2002;15:705-713

[19] Li D, Siriamornpun S, Wahlqvist ML, Mann NJ, Sinclair AJ. Lean meat and heart health. Asia Pacific Journal of Clinical Nutrition. 2005;14:113-119

[20] Lombardi-Boccia G, Aguzzi A, Cappelloni M, Di Lullo G, Lucarini M. Total-diet study: Dietary intakes of macro elements and trace elements in Italy. British Journal of Nutrition. 2003;90:1117-1121

[21] Dunshea FR, D'Souza DN, Pethick DW, Harper GS, Warner RD. Effects of dietary factors and other metabolic modifiers on quality and nutritional value of meat. Meat Science. 2005;71:8-38

[22] Klurfeld DM. Research gaps in evaluating the relationship of meat and health. Meat Science. 2015;109:86-95

[23] Givens DI, Kliem KE, Gibbs RA. The role of meat as a source of n-3 polyunsaturated fatty acids in the human diet. Meat Science. 2006;74:209-218

[24] Sahlin A, House JD. Enhancing the vitamin content of meat and eggs: Implications for the human diet. Canadian Journal of Animal Science. 2006;86:37-48 
[25] Lombardi-Boccia G, Lanzi S, Aguzzi A. Aspects of meat quality: Trace elements and B vitamins in raw and cooked meats. Journal of Food Composition and Analysis. 2005;18:39-46

[26] LR MD. Vitamins in Animal and Human Nutrition. 2nd ed. Iowa: Iowa State University Press; 2000

[27] Rivlin RS. Riboflavin. In: Bowman BA, Russell RM, editors. Present Knowledge in Nutrition. Washington: ILSI Press; 2001. pp. 191-198

[28] Said HM, Ortiz A, Subramanian VS, Neufeld EJ, Moyer MP, Dudeja PK. Mechanism of thiamine uptake by human colonocytes: Studies with cultured colonic epithelial cell line NCM460.AmericanJournalofPhysiology.GastrointestinalandLiverPhysiology.2001;281: G144-G150

[29] Tilman D, Clark M. Global diets link environmental sustainability and human health. Nature. 2014;515:518-522

[30] Calder PC, Yaqoob P. Omega-3 polyunsaturated fatty acids and human health outcomes. BioFactors. 2009;35:266-272

[31] McEvoy CT, Temple N, Woodside JV. Vegetarian diets, low-meat diets and health: A review. Public Health Nutrition. 2012;15:2287-2294

[32] Mozaffarian D, Appel LJ, Van Horn L. Components of a cardioprotective diet: New insights. Circulation. 2011;123:2870-2891

[33] Williams P. Nutritional composition of red meat. Nutrition and Dietetics. 2007;64: S113-S119

[34] Storcksdieck S, Bonsmann G, Hurrell RF. Iron-binding properties, amino acid composition, and structure of muscle tissue peptides from in vitro digestion of different meat sources. Journal of Food Science. 2007;72:19-28

[35] Razminowicz RH, Kreuzer M, Scheeder MRL. Quality of retail beef from two grass-based production systems in comparison with conventional beef. Meat Science. 2006;73:351-361

[36] Howe P, Meyer B, Record S, Baghurst K. Dietary intake of long-chain $\omega-3$ polyunsaturated fatty acids: Contribution of meat sources. Nutrition. 2006;22:47-53

[37] Given DI, Shingfield KJ. Food derived from animals: The impact of animal nutrition on their nutritive value and ability to sustain long-term health. Nutrition Bulletin. 2004; 29:325-332

[38] Rhee KS. Fatty acids in meats and meat products. In: Chow CK, editor. Fatty Acids in Foods and their Health Implications. 2nd ed. New York: Marcel Dekker; 2000. pp. 83-108

[39] Fang X, An P, Wang H, Wang X, Shen X, Li X, et al. Dietary intake of heme iron and risk of cardiovascular disease: A dose-response meta-analysis of prospective cohort studies. Nutrition, Metabolism, and Cardiovascular Diseases. 2015;25:24-35 
[40] White DL, Collinson A. Red meat, dietary heme iron, and risk of type 2 diabetes: The involvement of advanced lipoxidation end products. Advances in Nutrition. 2013;4:403-411

[41] Bastide NM, Chenni F, Audebert M, Santarelli RL, Tache S, Naud N, et al. A central role for heme iron in colon carcinogenesis associated with red meat intake. Cancer Research. 2015; 75:870-879

[42] Akiba S, Murata T, Kitatani K, Sato T. Involvement of lipoxygenase pathway in docosapentaenoic acid-induced inhibition of platelet aggregation. Biological \& Pharmaceutical Bulletin. 2000;23:1293-1297

[43] Pereira PMDCC, Vicente AFDRB. Meat nutritional composition and nutritive role in the human diet. Meat Science. 2013;93:586-592

[44] McNeill S, Van Elswyk ME. Red meat in global nutrition. Meat Science. 2012;92:166-173

[45] Baena Ruiz R, Salinas Hernández P. Diet and cancer: Risk factors and epidemiological evidence. Maturitas. 2014;77:202-208

[46] Larsen CS. Animal source foods and human health during evolution. The Journal of Nutrition. 2013;133:3893-3897

[47] Ulijaszek SJ, Mann N, Elton S. Evolving Human Nutrition: Implications for Public Health. Vol. 64. Cambridge University Press; 2012. ISBN: 9781139046794. https://doi.org/10.1017/ CBO9781139046794

[48] Leonard WR, Snodgrass JJ, Robertson ML. Effects of brain evolution on human nutrition and metabolism. Annual Review of Nutrition. 2007;27:311-327

[49] McHenry HM, Coffing K. Australopithecus to homo: Transformations in body and mind. Annual Review of Anthropology. 2000;29:125-146

[50] Leonard WR. Dietary change was a driving force in human evolution. Scientific American. 2002;287:106-116

[51] Wang WJ, Crompton RH. The role of load-carrying in the evolution of modern body proportions. Journal of Anatomy. 2004;204:417-430

[52] Speth JD. Early hominid hunting and scavenging: The role of meat as an energy source. Journal of Human Evolution. 1989;18:329-343

[53] Leroy F, Praet I. Meat traditions. The co-evolution of humans and meat. Appetite. 2015;90: 200-211

[54] Food and Agriculture Organization of the United Nations (FAO). World Livestock 2011: Livestock in Food Security. Rome: FAO; 2011

[55] Higgs JD. The changing nature of red meat: 20 years of improving nutritional quality. Trends in Food Science and Technology. 2011;11:85-95

[56] McAfee AJ, McSorley EM, Cuskelly GJ, Moss BW, Wallace JM, Bonham MP, et al. Red meat consumption: An overview of the risks and benefits. Meat Science. 2010;84:1-13 
[57] Chanson A, Brachet P, Grolie P, Rock E. Micronutrient intakes from meat. Sciences des Alimens. 2003;23:47-55

[58] Bou R, Guardiola F, Padró A, Pelfort E, Codony R. Validation of mineralization procedures for the determination of selenium, zinc, iron and copper in chicken meat and feed samples by ICP-AES and ICP-MS. Journal of Analytical Atomic Spectrometry. 2004;19:1361-1369

[59] Raymann MP. The importance of selenium in human health. Lancet. 2000;356:233-241 


\section{Section 2}

Composition of Meat with Reference to Fatty Acids 

Chapter 2

\title{
Fat Deposition, Fatty Acid Composition, and Its Relationship with Meat Quality and Human Health
}

\author{
Taiane da Silva Martins, \\ Marcos Vinícius Antunes de Lemos, \\ Lenise Freitas Mueller, Fernando Baldi, \\ Tamyres Rodrigues de Amorim, \\ Adrielle Matias Ferrinho, Julian Andres Muñoz, \\ Ingrid Harumi de Souza Fuzikawa, \\ Gabriella Vespe de Moura, \\ Jéssica Luana Gemelli and \\ Angélica Simone Cravo Pereira
}

Additional information is available at the end of the chapter

http://dx.doi.org/10.5772/intechopen.77994

\begin{abstract}
The consumer's profile has changed, and in recent years, there has been a greater concern for the nutritional quality of meat, especially in relation to fat that compose it. The meat fat composition can contribute to the onset of cardiovascular disease. On the other hand, fat is an essential component in the human diet, as well as providing energy; it contains essential fatty acids (FAs) that must be present in food. The meat nutritional properties are largely related to its fat content and fatty acid composition. In addition, fat gives flavor to food, helps in the absorption of vitamins, and plays an important role in the immune response, for humans, and animals. The fat nutritional and sensory quality in meat that is determined by the fatty acid composition can affect the degree of fat saturation, the storage stability, and flavor. There are several factors that can influence the fatty acid composition, such as animals' species, breed, sex, and diet, causing various changes in carcass, as well as in tissues and chemical meat composition.
\end{abstract}

Keywords: animal production, animal fat, lipid composition, flavor, polyunsaturated fatty acids, human nutrition 


\section{Introduction}

Meat provides important nutrients for the human diet, including vitamin B, minerals such as iron, and the essential fatty acids [1,2]. The fat deposition in muscles and the meat fatty acid (FA) composition are factors that affect the meat quality and primarily influence flavor, juiciness, and tenderness [3-5]; therefore, they are important in meat industry. The fat also assists in the transport and absorption of fat-soluble vitamins $\mathrm{A}, \mathrm{D}, \mathrm{E}$, and $\mathrm{K}$ by the intestine and plays an important role in the immune response, both in humans and in animals [6]. Furthermore, fat is related to the quality; protects the carcass from the cold; is considered a visual attractive, striking the meat acceptability by the consumer; and is associated with human health issues $[7,8]$.

For consumers, flavor and nutritional value are important attributes for meat quality and can influence the purchasing power [9]. However, currently, there is a growing concern not only about the fat excessive consumption but also its composition and impact on health, particularly those of animal origin [10]. The fatty acid profile of intramuscular fat is important for human health, since the intramuscular fat cannot be extracted or removed before consumption of meat [11]. The high consumption of saturated fatty acids (SFAs) is associated with elevation of serum cholesterol and low-density lipoproteins (LDL) which are risk factors for the occurrence of cardiovascular diseases [12]. For these reasons, the animal products are criticized, as they have a high SFA content and labeled as harmful to health $[6,13]$.

These concerns are based on recommendations in health authorities and nutritionists that support the notion that saturated fat from meat has negative impacts on health. However, in most cases, this information is widespread in digital media and disseminated without scientific support to "crucify" especially red meat, making it the villain to health. Therefore, further clarification of the actual impact of the meat and fat consumption to human health, considering other indirect factors related to its consumption, which can harm human health, such as physical inactivity, obesity, and intake of alcoholic beverages, among others, become necessary.

\section{Literature review}

\subsection{Fat deposition}

The development of adipose tissue also begins at the pre-birth, around the third month of pregnancy, when embryonic cells derived from the mesenchyme, like fibroblasts, differentiate to give rise to adipoblasts or primitive cells from adipose tissue. After differentiation, there is no way a cell return to the initial state. Once formed, the adipoblasts undergo an exponential multiplication phase forming preadipocytes [14]. Lipoprotein lipase (LPL) is the enzyme responsible for breaking down the triglycerides, caused by fatty acids, and glycerol circulation, endothelial and synthesized by the adipocyte level, also acts as a cell flag, since, when expressed, it stimulates a new wave hyperplastic adipose tissue [14]. After the occurrence of 
this new wave of proliferation, new adipocyte proliferation inhibitor cell signalers, such as glycerol-3-phosphate dehydrogenase (GPDH) and fatty acid synthase (FAD), are detected. The cells then receive the signal to initiate the accumulation of lipids, when they become termed themselves adipocytes [14].

During differentiation, preadipocytes undergo morphological changes as well as the selective expression of certain genes. The sequential expression of certain transcription factors, such as the CCAAT/enhancer-binding protein factor, SREBP/sterol regulatory element-binding protein, and the family of transcription factors PPAR/proliferator-activated receptor peroxisome, have a key role in the conversion stages of adipocytes [15].

The deposition of intramuscular fat is apparently regulated by different factors when compared with those regulating fat depositions in fatty tissues, such as subcutaneous, metabolic differences existing between them. Intramuscular adipocytes have higher activity of the enzymes hexokinase and phosphofructokinase. The subcutaneous adipose tissue exhibits higher levels of lipogenic enzymes such as NADP-malate dehydrogenase, fosfogluconate6-dehydrogenase, and glucose-6-phosphate dehydrogenase, showing unique roles in lipid metabolism [16, 17].

The adipose tissue mass, therefore, is controlled by the balance between cell proliferation (hyperplasia) and increased cell size (hypertrophy). The uptake of free fatty acids in the cytosol full of lipid droplets in triacylglycerol contributes to adipocyte hypertrophy [14]. In ruminants, adipocytes play an important role as energy reserve, and occasioning changes in animal fat deposition in accordance with their physiological state, such as during pregnancy or termination phase. In addition, adipocytes act as true endocrine cells, secreting several hormones and endocrine signals which are directly related to animal production. Among these substances, leptin, IGF-1, interleukins, and resistin, among others, stand out [18].

The deposition of fat in cattle, as well as other animal species, is reflected by nutrition and sex and used for the genetic group [19]. Thus, there is a wide interest in manipulating the chemical composition of meat, through the regulation of its biosynthesis. For better understanding of the effects of nutrition on lipid metabolism and consequently on the quality of meat, recent research has made association between gene expression and nutrition area known as nutrigenomics [20-23].

Gene expression is the process whereby information contained in the DNA structure is transmitted to the mRNA and protein products [24]. The binding of specific transcription factors to specific DNA sequences controls this process. The key transcriptional factors involved in lipid metabolism regulatory elements are proteins related to sterol (SREBP-1c) [25], the activated receptor peroxisome proliferator- $\gamma$ (PPAR), and proliferator-activated receptor peroxisome- $\alpha$ (PPAR $\alpha)$. These genes were associated with the synthesis and oxidation of fatty acids in the different organs and tissues of the animal body [26, 27].

The interactions between the nutrients that compose the diet and the synthesis and activity of lipogenic enzymes can illustrate the numerous possibilities regarding lipid deposition in adipose tissue. This is possible because the biological activity displayed by certain dietary fatty 
acids can stimulate or inhibit specific lipogenic genes encoding enzymes [22]. For example, sources of polyunsaturated fatty acids (PUFAs) can increase transcription of genes that encode the lipoprotein lipase enzyme (LPL); the connector transporter to fatty acid 4 (FABP4), PPAR $\alpha$ [28], and PPAR [26]; and decrease expression of the gene encoding stearoyl-CoA desaturase (SCD1) [21] and SREBP-1c [29].

The oleic acid concentration presents in the meat bovine fat if dependent of the expression of stearoyl-CoA desaturase (SCD) and its activity. SCD has been identified and reported as one of the genes associated with fatty acid composition of beef. This is a limitation of SFA responsible for the conversion of monounsaturated fatty acids (MUFAs) in mammalian adipocytes. The composition of the fatty acids stored in fat deposits reflects the previous action SCD substrates such as stearic acid and palmitic acid [30]. Accordingly, higher levels of concentrate feed in the finishing period of the animals confined result in a higher concentration of oleic acid and MUFA in the intramuscular fat [31]. Although the adipogenic mechanism is extremely complex, several genes were identified and confirmed as being responsible for fatty acid composition in beef [20, 32-41].

\subsection{Fatty acid composition and its relationship with human health}

Besides its importance for the sensory characteristics of the meat, the fat content and their FA composition are relevant to the quality, especially for issues related to human health [42, 43]. The composition of the FA of animal origin can be influenced by diet (forage and grain), by the digestive system, and by the biosynthetic processes of the animal [44]. In ruminants, the FA's profile is not a direct reflection of FA composition from the feed due to the complex reactions of biohydrogenation caused by rumen microorganisms [8, 16, 42].

Furthermore, the FA composition may also be different depending on the breed, species (Table 1) [13, 45], and sexual condition [46, unpublished data]. Wood et al. [13] showed that the meat has an average $50 \%$ of SFA, $40 \%$ of MUFA, and $10 \%$ of PUFA acids. The meat FAs are mainly medium to long chain, from 12 to 22 carbon atoms, with the basic structure $\mathrm{CH}_{3}-\left(\mathrm{CH}_{2}\right)$ $\mathrm{n}-\mathrm{COOH}$. Low concentrations of FA short-chain C8-C10 are observed in mutton fat [13].

In general, the meat fat of the ruminant has a higher concentration of SFA and lower polyunsaturated:saturated relationshipcompared to thenonruminantmeat. Thisfactis duetothe FA of biohydrogenation process unsaturated on rumen by the action of microorganisms [46-48]. However, not all SFAs are considered hypercholesterolemic (which increase the levels of bad cholesterol (LDL)). The most undesirable FA, according to French et al. [49], would be myristic acid (C14:0), which represents only $3 \%$ of total FA in meat [50]. Howsoever, the main SFAs present in beef intramuscular fat are the palmitic (C16:0) and stearic (C18:0) acids, which make up more than $50 \%$ of the total lipid composition [51-53]. The presence of SFA in beef is the main cause of concern and associations of human health with cardiovascular disease and obesity, by influencing cholesterol blood levels [54].

However, palmitic FA has lower hypercholesterolemic effect and stearic FA (43\% of total SFA in meat [50], has no effect because it becomes oleic acid (C18: $1 \mathrm{n}-9)$ in the body [55], and thus does not influence blood cholesterol levels. The intramuscular fat beef also has a higher 


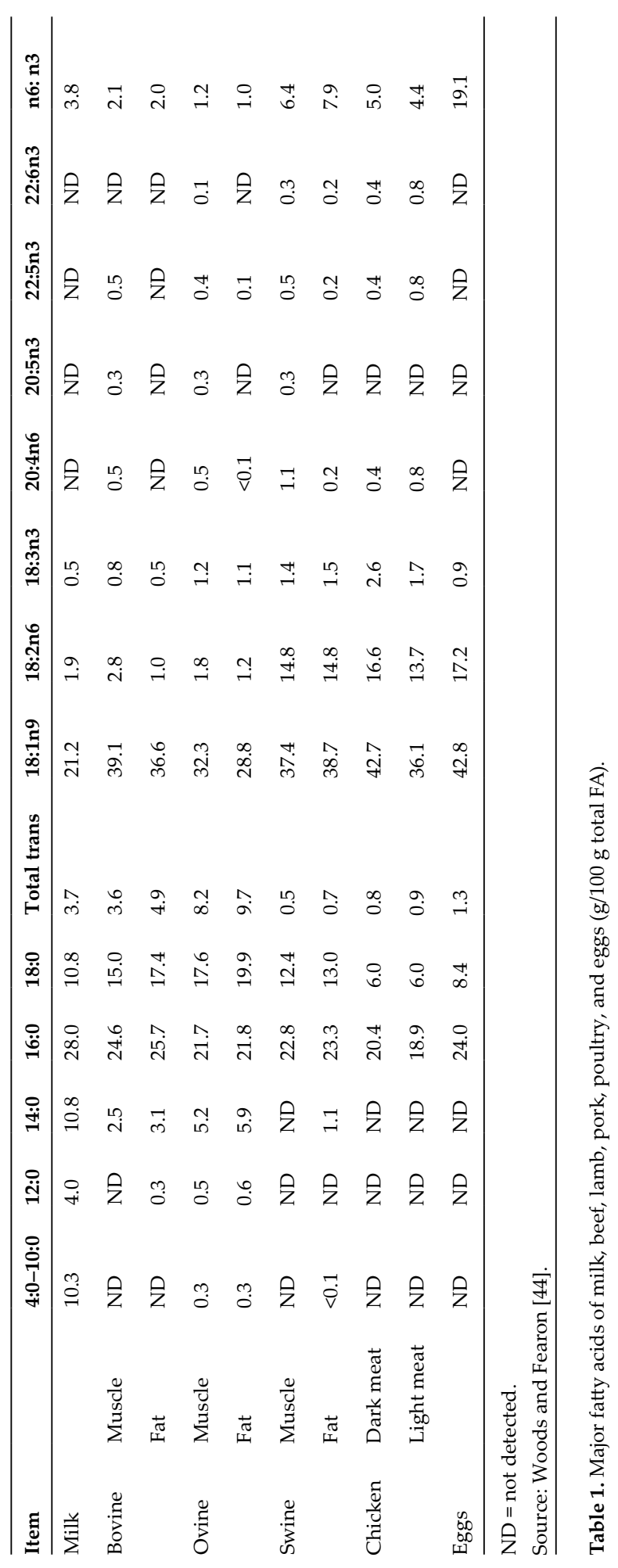


overall concentration of MUFA, mainly oleic acid and polyunsaturated fatty acids (PUFAs). Oleic acid may decrease the circulating concentration of LDL cholesterol in humans and is considered a "healthy" fat [56-61]. Higher oleic acid values are desirable for having hypocholesterolemic action, with the advantage of not lower HDL cholesterol (good cholesterol), and act to protect against coronary heart disease [50].

The relation between $\mathrm{n} 6$ and $\mathrm{n} 3$ is particularly beneficial (balanced) in meat from ruminants. These FAs have several effects on the immune and inflammatory response. The n-3 FA has suppressive effects such as inhibition of lymphocyte proliferation, antibody production, and cytokine expression of adhesion molecules and activation of natural killer cells (NK). The n-6 FA has both effects: inhibitory and stimulating the immune response [60]. The balance of daily intake of foods that are sources of FA n- 6 and n-3 is important in human health, and recommendations vary according to some authors and countries. The trend of convergence of the $n-6: n-3$ ratio of FA is in the range from $4: 1$ to 5:1 [61-63]. The essential FAs include the $n-3$ and n- 6 families, which are not biologically synthesized by humans, but they are necessary for biological processes and therefore should be eaten in the human diet.

After n-3 ingestion, the FA biosynthesis of eicosapentaenoic acid-C20:5 (EPA) and docosahexaenoic acid-C22:6 (DHA) occurs in the body. The first FA is involved in cardiovascular protection in adults [64], and the second is essential for brain development and visual system, associated with maternal and child health [65].

The arachidonic acid (C20:4 n-6) and EPA give rise to eicosanoids, thromboxanes, prostaglandins, and leukotrienes. Their presence in the bloodstream can provide vasoconstrictor responses or vasodilator, stimulation or inhibition of platelet aggregation, and pro effects or anti-inflammatory drugs $[66,67]$.

The conjugated linoleic acid (CLA) is a representative of micro-components in animal products, with a mixture of FA, which occurs as intermediate biohydrogenation of PUFAs [68]. This substance is interesting to act as a powerful natural anticarcinogenic and reduce atherosclerosis and diabetes [69].

The red meat consumption and cardiovascular disease, obesity, and colon cancer are mainly due to the saturated fat content $[70,71]$. On the other hand, more recent studies indicate that processed meats, not the red fresh beef, increase the risk of cardiovascular disease and obesity [72]. However, other researchers have shown the benefits of lean meat as part of a healthy diet [73-75]. Furthermore, the meat with higher fat content produces lower levels of mutagenic heterocyclic aromatic amines, especially pasture-fed animals [76], indicating that the consumption of beef presents additional benefit.

According to Oostindjer et al. [77], data on associations between red meat intake and colorectal cancer are inconsistent, and the underlying mechanisms are unclear. Therefore, it is unlikely that moderate consumption of red meat as part of a balanced diet increases the chances of cardiovascular disease or colon cancer [78].

\subsection{The influence of diet on the meat fatty acid composition}

The animal's diet has been demonstrated as one of the factors determining the different changes in carcass composition and tissue as well chemistry of meat cuts [79]. The concentrated and 
bulky proportions and their respective sources are some of the factors which determine the quantity and quality of lipids present in animal products [80, 81].

The biohydrogenation process of unsaturated FA that happens in the rumen, and the composition of FAs in the ruminant's meat, can be affected by breed, diet composition, and management $[8,13,42,45,82]$. Still, the factors that influence the chemical and physical components present in the meat can mention the age, sex, and anatomical location of cutting and the muscle [83]. Comparisons between eight different meat cuts showed that composition of breast fatty acids presented lower concentrations of stearic and palmitic acids, lower myristic concentrations, and higher MUFA concentrations represented by oleic acid [84].

The age specifically affects the MUFA content by means of SCD gene expression and enzyme activity [85]. Typically, the MUFA:SFA relationship increases with age, in muscle neutral lipids, and total fat of cattle $[13,85]$. The inclusion of sources of MUFA in animal diet improves milk, meat, and eggs FA profile by increasing the proportion of MUFA:SFA, reducing the proportion of n6:n3 FA and increasing CLA levels in ruminant products [44]. However, one should take precautions as the addition of these sources of FA in animal diets may result in some adverse effects. For example, large quantities of MUFAs in the diet can affect ruminal activity, reducing milk production, and the concentrations of fat and protein, while the increase in PUFA levels in meat could result in lower maintenance and worse taste in meat products [44].

French et al. [46] observed that the longissimus dorsi muscle in ruminants fed with grasses showed a higher CLA production, two to three times as compared with the meat of ruminants fed with feedlot diets with high grain content. Accordingly, several subsequent studies have shown that the use of forage in the diet significantly increases the percentage of CLA, especially cis- 9 and trans-11, up to twice the total fatty acids found in meat from animals which received greater proportion of grain in the diet [86-89].

The use of grain in cattle feed feedlot during the termination period is directly responsible for difference between FA compositions. Cattle fed with grain increases the absolute monounsaturated and saturated fat content of the meat while simultaneously decreasing absolute content of n-3 [89, 90].

Accordingly, Ferrinho et al. [91] observed differences in FA composition as a function of the cottonseed inclusion level in the diet. The total SFAs were not affected by diet, but differences were observed for branched chain fatty acids (BCFA), cis- and trans-monounsaturated fatty acid (MUFAcis/trans), unconjugated (nc) dienes, and in some individual PUFA. The BCFA and MUFAcis levels were higher in meat from cattle fed with the control diet compared with those receiving cottonseed.

Similarly, Díaz [92] reported that FA composition observed in longissimus dorsi and quadriceps femoris of lambs resulted in low percentage of stearic acid and high palmitic and linoleic acid values when compared to animals maintained on pasture. This difference is due to the FA composition in the diet, since fodder contains higher levels of linolenic FA and precursor n-3 series fans. In contrast, the concentrate has a high content of linoleic acid, the precursor of the $n-6$ series [93].

Likewise, Pelegrini et al. [94] evaluated the FA profile of sheep meat terminated at pasture or confinement observing a higher content of PUFAs in animals kept on pasture. This variation of the fat composition is responsible for the characteristic flavor of the meat of animals whose diet was based on pasture or concentrated [92]. 
In monogastric domestic animals, it is possible to change the composition of the FA of meat in the diet, since the FA in the diet is absorbed by the intestine unchanged and embedded tissues. Linoleic acid, for example, is not synthesized, and the concentrations present in the tissues respond rapidly to changes in diet. In contrast, MUFAs and SFAs are synthesized and are less influenced by the diet [95].

Morel et al. [96] studied the effect of fat sources in the diet on the FA profile in the pigs' meat and reported that diets rich in PUFAs increase the levels of linoleic acid $(18,2)$ and linolenic acid (C18:3) in muscle longissimus dorsi and subcutaneous fat. The composition of the poultry carcasses can also be altered by the type and amount of FA diet. Supplementation with unsaturated FA enables the deposition of these tissues in poultry [97]. Broilers require high energy concentrations in the feed, making it necessary to use oils, which eventually will influence the meat FA composition [98]. Increasing the proportion of n-3 series in the diet may have a beneficial effect regarding the nutritional quality of poultry meat and then decrease the levels of total lipids and cholesterol [97].

In a study using oil in chicken diet with the aim to evaluate the effect of different dietary lipid sources, the author reported that the chickens fed with the offal fat diet showed a higher percentage of MUFAs in the carcass and significant values of the palmitoleic acid. Besides, the linoleic acid was found to have high concentration in soybean oil [99], which confirms that the FA profile in the substrate is influenced by dietary fat sources used [100]. Subsequently, the effects of CLA supplementation in poultry diet during growth, diets containing different percentages of CLA ranging from $0 \%$ to $1.5 \%$, were evaluated. It was observed that as increased levels of CLA in the diet, CLA is increased accumulation-in meat and decreased abdominal fat of poultry [101].

\subsection{Genetic factor that influence the fatty acid composition}

There is a growing market demand for healthier fat sources, and several strategies have been used to improve the meat FA profile, such as dietary manipulation and animal breeding. However, the high cost to obtain the phenotypic information and the fact that this trait can be only obtained after slaughter limits the genetic improvement through traditional selection. Although FA profile is not considered selection criteria, genomic selection is an important tool to improve the genetic progress of this trait, since the animal can be availed early in life, even at birth, reducing the generation interval and low cost [32]. In this sense, Cesar et al. [37] and Aboujaoude et al. [35] reported that selection for beef FA profile in Zebu cattle is very feasible, since there is additive genetic variation for most beef fatty acids in Zebu cattle.

Therefore, information on the genetic differences between breeds and genetic parameters to develop breeding programs are essential. Thus, estimates of heritability and genetic and phenotypic correlations are key attributes. Differences in the fatty acid composition between purebred and crossbred cattle has been extensively evaluated on different production systems. In contrast, genetic studies reporting parameters (heritability and genetic correlations) for fatty acid profile are plentiful for monogastric animals, particularly pigs but, however, are still scarce in cattle, or the number of data used is limited [102].

However, estimates of parameters of genetic or genetic variability within breeds for fatty acid composition have been widely studied. Currently, the availability of genomic data for selection of traits associated with meat quality and lipid profile in cattle has increased [103], 
since there is a collection of information by research institutions, especially in Nellore herds $[32,35,37,104]$.

Heritability estimates for the meat fatty acid profile have been different in magnitude and, as a result, probably different in populations and used data structure, applied estimation methods, sampled tissue, etc. Furthermore, when comparing the estimates obtained in different breeds, differences in the activity of enzymes related to fatty acid desaturation can influence the estimated genetic variability [105]. Heritabilities and genetic correlations to fatty acid proportion were estimated to correspond to some studies and observations of the phenotypic level compared to the level of intramuscular fat [11].

Methods such as SNP-BLUP (single nucleotide polymorphism-best linear unbiased predictor) have been proposed to predict the genomic breeding values. This method allows to obtain less biased and applicable genomic evaluations, which is the most viable method when considering the computational cost [32].

Various fatty acids were identified positively and negatively in different biological processes in the skeletal muscle and other tissues. Knowing the biological processes associated with fatty acid content in the skeletal muscle and identifying differentially expressed genes (DEG) and functional pathways related to the regulation of gene expression associated with the fatty acid profile contribute to the understanding of how some FAs modulate metabolism and may have a protective function for health [36] as well as its potential for use in animal selection.

\subsection{Effects of fatty acids on meat quality}

The proportions of intramuscular fat present in the meat as well as its composition are associated with the juiciness, flavor, tenderness, and overall acceptability [106]. Besides these traits, the meat shelf life (pigment and lipid oxidation) is influenced by the composition thereof.

The FAs are involved in various technological aspects of meat quality because they have different fusion points. Groups of fat cells containing fat solidified with a high fusion point are whiter than when it contains liquid fat with a lower fusion point. This fat has another color, and appearance quality is affected by the FA [8]. The adipose tissue of ruminants is naturally firmer than that of pigs because the FA profile is more saturated. In bovine finishing period, the concentration of SFA in relation to the unsaturated increases, but beyond a certain level of fat in the animal, this ratio decreases. In fatty cattle the fat is soft, mainly due to an increase in relation to the oleic stearic and palmitic acids [107].

However, $90 \%$ of the volatile compounds in the meat, subjected to a cooking method, arise from the oxidation of unsaturated FA [108]. These volatile compounds contribute to the flavor and odor of meat, and unsaturated FAs are particularly important in the development of flavor [109], since the FA degradation of the n-9 family can produce hexanal, heptenol, decanal, octanal, heptanal, and nonanal. The oxidation of n-3 fatty acids gives rise to 1-penten-3-ol and propanal, and degradation of n-6 fatty acids will form hexanal, pentanal pentylfuran, pentanol, hexanol, 1-octenol, and 2-octenol [110].

Correspondingly, the group of aldehydes (pentanal, hexanal, hexenal, heptanal, nonanal, octenal, octanal) is the most frequently identified in meat samples submitted to cooking; among them it is possible to highlight hexanal, which represents about $90 \%$ of total aldehydes, and it 
can be produced from the oxidation of oleic, linoleic, and arachidonic fatty acids and degradation from other aldehydes, such as 2,4-decadienal [111].

The color change is due to the oxidation of oxymyoglobin (red) to metmyoglobin (brown), and this reaction usually occurs along the rancidity. Li and Liu [112] have shown that lipid oxidation products can promote the oxidation of the pigment and vice versa, although the strength of the relationship between these two aspects of shelf life is sometimes low. Antioxidants, in particular $\alpha$-tocopherol (vitamin E), have been used to retard lipid oxidation and color in addition to prolong the life of meat products $[113,114]$.

Warren et al. [115] compared the grazing pasture-fed and grain-fed cattle and found that bright red color associated with oxymyoglobin was retained longer, simulating retail condition in cattle fed on pasture. Although the total concentration of unsaturated FA was similar in both groups, the animals were grazing beef with high concentrations of $n-3$ and the feed grain increased levels of $n-6$. It was found that antioxidants naturally present in the pasture probably caused higher levels of vitamin $\mathrm{E}$ in the tissue of these animals, with benefits to lower lipid oxidation and better color retention.

In studies with sheep, Kasapidou et al. [116] reported that low concentrations of vitamin E in the fabric are associated with lesser amounts of both n- 6 and n-3 FAs in tissues. This suggests that the loss of in vivo PUFAs occurs when the antioxidant status is low. It is well known that marbling plays an important role in meat quality and sensory palatability of beef [53]. It has also been shown that in some countries growing score marbling corresponds to more acceptable taste, greater juiciness, bigger texture, and therefore greater palatability and acceptability [51, 117-120].

These results implied that high concentrate grain-fed beef could increase intramuscular fat (IMF) content and the proportion of oleic acid, thus increasing the sensory palatability of Hanwoo beef [53]. Lee et al. [121] reported differences between gene expression of FABP4, SCD, PPAR $\gamma$, titin, and nebulin in longissimus muscle from high- and low-marbled Hanwoo steers. PPAR $\gamma$ and SCD gene were highly expressed in the low-marbled group, the SCD being related to the FA profile of the meat and the conversion of stearic acid to oleic acid. The SCD gene was associated with fatty acid composition and converts stearic acid into oleic acid. However, the FABP4 gene had a higher gene expression pattern in the high-marbled group relative to the low-marbled group.

\section{Final consideration}

It is already known that the fat contains essential fatty acids that must be present in the feed, to providing more energy than carbohydrates and proteins. Fat also provides flavor to food, assisting in the transport and absorption of fat-soluble vitamins A, D, E, and $\mathrm{K}$ by the intestine and plays a major role in the immune response, both in humans and animals. Thus, fat consumption that contains good fatty acid quality is essential while assisting in reducing the consumption of foods rich in simple carbohydrates, once the excessive intake of these compounds is detrimental to health. 
The fatty acid composition of both adipose tissue and domestic animal muscle tissue depends on numerous factors, including intrinsic factors such as species, breed, genetics and age, and extrinsic factors such as food. These factors have direct effects on the meat quality. It is noteworthy also that the digestion of lipids present in the diet depends on the animal species.

Today, the search for healthy foods that meet the requirements of consumers in its qualitative aspect as nutrition, increasing concentrations of CLA, respecting the reasons of PUFA:SFA, n6: n3, stipulated by public health authorities is crucial, in order to prevent the development of cardiovascular disease and a possible incidence of some types of tumors and diabetes, among others.

Given the above, it is noted that the fat deposition and fatty acid profiles have great influence on meat quality evaluations, and its association with human health should be undertaken with caution and greater scientific support. However, additional studies are necessary to elucidate the real impact of fat consumption on human healthy.

\section{Author details}

Taiane da Silva Martins ${ }^{1}$, Marcos Vinícius Antunes de Lemos ${ }^{3}$, Lenise Freitas Mueller², Fernando Baldi ${ }^{3}$, Tamyres Rodrigues de Amorim², Adrielle Matias Ferrinho², Julian Andres Muñoz ${ }^{2}$, Ingrid Harumi de Souza Fuzikawa², Gabriella Vespe de Moura², Jéssica Luana Gemelli ${ }^{2}$ and Angélica Simone Cravo Pereira ${ }^{1 *}$

*Address all correspondence to: angelpereira@usp.br

1 University of Sao Paulo, Faculty of Veterinary Medicine and Animal Science, Pirassununga, Sao Paulo, Brazil

2 University of Sao Paulo, Faculty of Animal Science and Food Engineering, Pirassununga, Sao Paulo, Brazil

3 Sao Paulo State University, Faculty of Agrarian and Veterinary Sciences of Jaboticabal, Jaboticabal, Sao Paulo, Brazil

\section{References}

[1] Pereira PM, Vicente AF. Meat nutritional composition and nutritive role in the human diet. Meat Science. 2013;93(3):586-592. DOI: 10.1016/j.meatsci.2012.09.018

[2] Williams P. Nutritional composition of red meat. Nutrition and Dietetics. 2007;64: S113-S119. DOI: 10.1111/j.1747-0080.2007.00197.x

[3] Wood JD. Consequences for meat quality of reducing carcass fatness. In: Wood JD, Fisher AV, editors. Reducing Fat in Meat Animals. London: Elsevier Applied Science; 1990. pp. 344-397 
[4] Wood JD, Enser M, Fisher AV, Nute GR, Richardson RI, Sheard PR. Manipulating meat quality and composition. Proceedings of the Nutrition Society. 1999;58:363-370. DOI: org/10.1017/S009665199000488

[5] Webb EC. Manipulating beef quality through feeding. South African Animal Science. 2006;7:5-15

[6] Webb EC, O'Neill HA. The animal fat paradox and meat quality. Meat Science. 2008;80:28-36. DOI: 10.1016/j.meatsci.2008.05.029

[7] Shingfield KJ, Bonnet M, Scollan ND. Recent developments in altering the fatty acid composition of ruminant-derived foods. Animal. 2013;7(1):132-162. DOI: 10.1017/S1751731 112001681

[8] Wood JD, Richardson RI, Nute GR, Fisher AV, Campo MM, Kasapidou E, Enser M. Effects of fatty acids on meat quality: A review. Meat Science. 2004;66(1):21-32. DOI: 10.1016/S0309-1740(03)00022-6

[9] Forrest JC, Aberle ED, Hedrick HB, Judge MD, Merkel RA. Principles of Meat Science. San Francisco: W.H. Freeman and Co.; 1975. p. 417

[10] Scollan ND, Dannenberger D, Nuernberg K, Richardson I, MacKintosh S, Hocquette JF, Moloney AP. Enhancing the nutritional and health value of beef lipids and their relationship with meat quality. Meat Science. 2014;97(3):384-394. DOI: 10.1016/j.meatsci.2014. 02.015

[11] De Smet S, Raes K, Demeyer D. Meat fatty acid composition as affected by fatness and genetic factors: A review. Animal Research. 2004;53:81-98. DOI: 10.1051/animres:2004003

[12] Katan MB, Zock PL, Mensink RP. Effects of fats and fatty acids on blood lipids in humans: An overview. The American Journal of Clinical Nutrition. 1994;60:1017-1022

[13] Wood JD, Enser M, Fisher AV, Nute GR, Sheard PR, Richardson RI, Hugles SI, Whittington FM. Fat deposition, fatty acid composition and meat quality: A review. Meat Science. 2008;78(4):343-358. DOI: 10.1016/j.meatsci.2007.07.019

[14] Hossner KL. Hormonal Regulation of Farm Animal Growth. Vol. 221. Department of Animal Sciences, Colorado State University, Fort Collins, Colorado,USA: CABI Publishing; 2005. DOI: $10.1079 / 9780851990804.0000$

[15] Gregorie FM, Smas CM, Sul HS. Understanding adipocyte differentiation. Physiological Reviews. 1998;78(3):783-809. DOI: 10.1152/physrev.1998.78.3.783

[16] Miller MF, Cross HR, Lunt DK, Smith SB. Lipogenesis in acute and 48h cultures of bovine intramuscular and subcutaneous adipose tissue explants. Journal of Animal Science. 1991;69(2):162-170. DOI: 10.2527/1991.691162x

[17] May SG, Savell JW, Lunt DK, Wilson JJ, Laurenz JC, Smith SB. Evidence for preadipocyte proliferation during culture of subcutaneous and intramuscular adipose tissues from Angus and Wagyu crossbred steers. Journal of Animal Science. 1994;72(12):3110-3117. DOI: $10.2527 / 1994.72123110 x$ 
[18] Miner JL. The adipocyte as an endocrine cell. Journal of Animal Science. 2004;82(3): 935-941. DOI: $10.2527 / 2004.823935 x$

[19] Mapiye C, Aalhus JL, Turner TD, Rolland DC, Basarab JA, Baron VS, McAllister TA, Block HC, Uttaro B, Lopez-Campos O, Proctor SD, Dugan ME. Effects of feeding flaxseed or sunflower-seed in high-forage diets on beef production, quality and fatty acid composition. Meat Science. 2013;95:98-109. DOI: 10.1016/j.meatsci.2013.03.033

[20] Teixeira PD, Oliveira DM, Chizzotti ML, Chalfun-Junior A, Coelho TC, Gionbelli M, Paiva LV, Carvalho JRR, Ladeira MM. Subspecies and diet affect the expression of genes involved in lipid metabolism and chemical composition of muscle in beef cattle. Meat Science. 2017;133:110-118. DOI: 10.1016/j.meatsci.2017.06.009

[21] Herdmann A, Nuernberg K, Martin J, Nuernberg G, Doran O. Effect of dietary fatty acids on expression of lipogenic enzymes and fatty acid profile in tissues of bulls. Animal, Cambridge. 2010;4(5):755-762. DOI: 10.1017/S1751731110000431

[22] Jump DB. Dietary polyunsaturated fatty acids and regulation of gene transcription. Current Opinion in Lipidology. 2002;13(2):155-165

[23] OliveiraDM,Chalfun-JuniorA,ChizzottiML,BarretoHG,CoelhoTC,PaivaLV,LadeiraMM. Expression of genes involved in lipid metabolism in the muscle of beef cattle fed soybean or rumen-protected fat, with or without monensin supplementation. Animal Science. 2014;92(12):5426-5436. DOI: 10.2527/jas.2014-7855

[24] Eggen A, Hocquette JF. Genomic approaches to economic trait loci and tissue expression profling: Application to muscle biochemistry and beef quality. Meat Science. 2004;66(1):1-9. DOI: 10.1016/S0309-1740(03)00020-2

[25] Xu J, Teran-Garcia M, Park JH, Nakamura MT, Clarke SD. Polyunsaturated fatty acids suppress hepatic sterol regulatory element-binding protein-1 expression by accelerating transcript decay. Journal of Biological Chemistry. 2001;276(13):9800-9807. DOI: 10.1074/ jbc.M008973200

[26] Bionaz M, Chen S, Khan MJ, Loor JJ. Functional role of PPARs in ruminants: Potential targets for fine-tuning metabolism during growth and lactation. PPAR Research. 2013;2013:1-28. DOI: 10.1155/2013/684159

[27] Takanada I, Kouzmenko AP, Katos S. Wnt and PPAR gamma signaling in osteoblastogenesis and adipogenesis. Nature Reviews Rheumatology. 2009;5(8):442-447. DOI: 10.1038/nrrheum.2009.137

[28] Kersten S. Integrated physiology and systems biology of PPAR $\alpha$. Molecular Metabolism. 2014;3(3):354-371. DOI: 10.1016/j.molmet.2014.02.002

[29] Botolin D, Wang Y, Christian B, Jump DB. Docosahexaenoic acid (22:6, n-3) regulates rat hepatocyte SREBP-1 nuclear abundance by Erk-and 26S proteasome-dependent path ways. Journal of Lipid Reaserach. 2006;47(1):181-192. DOI: 10.1194/jlr.M500365JLR200 
[30] Kim YC, Ntambi JM. Regulation of stearoyl-CoA desaturase genes: Role in cellular metabolism and preadipocyte differentiation. Biochemical and Biophysical Research Communications. 1999;266(1):1-4. DOI:10.1006/bbrc. 1999.1704

[31] Seon-Tea J, Young-Hwa H, Damian F. Characteristics of Hanwoo cattle and health implications of consuming highly marbled Hanwoo beef. Meat Science. 2017;132:45-51. DOI: 10.1016/j.meatsci.2017.04.262

[32] Chiaia HL, Peripoli E, Silva RM, Aboujaoude C, Feitosa FL, Lemos MV, Berton MP, Olivieri BF, Espigolan R, Tonussi RL, Gordo DG, Bresolin T, Magalhães AF, Júnior GA, Albuquerque LG, Oliveira HN, Furlan JJ, Ferrinho AM, Mueller LF, Tonhati H, Pereira ASC, Baldi F. Genomic prediction for beef fatty acid profile in Nellore cattle. Meat Science. 2017;128:60-67. DOI: 10.1016/j.meatsci.2017.02.007

[33] De Souza RT, Chizzotti ML, Vital CE, Baracat-Pereira MC, Barros E, Busato KC, Gomes RA, Ladeira MM, da Silva Martins T. Differences in beef quality between Angus (Bos taurus taurus) and Nellore (Bos taurus indicus) cattle through a proteomic and phosphoproteomic approach. PLoS One. 2017;12(1):e0170294. DOI: 10.1371/journal.pone.0170294

[34] Martins TS, Sanglard LMP, Silva W, Chizzotti ML, Rennó LN, Serão NVL, Silva FF, Guimarães SEF, Ladeira MM, Dodson MV, Du M, Duarte MS. Molecular factors underlying the deposition of intramuscular fat and collagen in skeletal muscle of Nellore and Angus cattle. PLoS One. 2015;10(10):e0139943. DOI: 10.1371/journal.pone.0139943

[35] Aboujaoude C, Pereira ASC, Feitosa FLB, Lemos MVA, Chiaia HLJ, Berton MP, Baldi F. Genetic parameters for fatty acids in intramuscular fat from feedlot-finished Nellore carcasses. Animal Production Science. 2016. DOI: 10.1071/AN16107

[36] Cesar ASM, Regitano LCA, Poleti MD, Andrade SCS, Tizioto PC, Oliveira PSN, Felício AM, Nascimento ML, Chaves ASC, DPD1 L, Tullio RR, Nassu RT, Koltes JE, Fritz-Waters E, Mourão GB, Zerlotini-Neto A, Reecy JM, Coutinho LL. Differences in the skeletal muscle transcriptome profile associated with extreme values of fatty acids content. BMC Genomics. 2016;17(1):961. DOI: 10.1186/s12864-016-3306-x

[37] Cesar AA, Regitano LC, Mourão GB, Tullio RR, Lanna DP, Nassu RT, Coutinho LL. Genome-wide association study for intramuscular fat deposition and composition in Nellore cattle. BMC Genetics. 2014;15:1-15. DOI: 10.1186/1471-2156-15-39

[38] Giusti J, Castan E, Dal Pai M, Arrigoni MDB, Baldin SR, De Oliveira HN. Expression of genes related to quality of Longissimus dorsi muscle meat in Nellore (Bos indicus) and Canchim (5/8 Bos taurus $\times$ 3/8 Bos indicus) cattle. Meat Science. 2013;94(2):247-252. DOI: 10.1016/j.meatsci.2013.02.006

[39] Wei S, Duarte MS, Zan L, Du M, Jiang Z, Guan L, Chen J, Hausman GJ, Dodson MV. Cellular and molecular implications of mature adipocyte dedifferentiation. Journal of Genomics. 2013;1:5. DOI: 10.7150/jgen.3769

[40] Wei S, Du M, Jiang Z, Duarte MS, Fernyhough-Culver M, Albrecht E, Will K, Zan L, Hausman GJ, Elabd EMY, Bergen WG, Basu U, Dodson MV. Bovine dedifferentiated 
adipose tissue (DFAT) cells: DFAT cell isolation. Adipocytes. 2013;2(3):148-159. DOI: 10.4161/adip.24589

[41] Duarte MS, Paulino PV, Das AK, Wei S, Serão NV, Fu X, Harris SM, Dodson MV, Du $\mathrm{M}$. Enhancement of adipogenesis and fibrogenesis in skeletal muscle of Wagyu compared with Angus cattle. Journal of Animal Science. 2013;91(6):2938-2946. Epub 2013/03/20. DOI: $10.2527 /$ jas.2012-5892 pmid:23508025

[42] Enser M, Hallett KG, Hewett B, Fursey GAJ, Wood JD, Harrington G. Fatty acid content and composition of UK beef and lamb muscle in relation to production system and implications for human nutrition. Meat Science. 1998;49(3):329-341. DOI: 10.1016/ S0309-1740(97)00144-7

[43] Pighin D, Pazos A, Chamorro V, Paschetta F, Cunzolo S, Godoy F, Grigioni G. A contribution of beef to human health: A review of the role of the animal production systems. The Scientific World Journal. 2016. DOI: 10.1155/2016/8681491

[44] Woods VB, Fearon AM. Dietary sources of unsaturated fatty acids for animals and their transfer into meat, milk and eggs: A review. Livestock Science. 2009;126:1-20. DOI: 10.1016/j.livsci.2009.07.002

[45] Smith SB, Lunt DK, Chung KY, Choi CB, Tume RK, Zembayashi M. Adiposity, fatty acid composition, and delta-9 desaturase activity during growth in beef cattle. Animal Science Journal. 2006;77:478-486. DOI: 10.1111/j.1740-0929.2006.00375.x

[46] French P, Stanton C, Lawless F, O'Riordan EG, Monahan FJ, Caffrey PJ, Moloney AP. Fatty acid composition, including conjugated linoleic acid of intramuscular fat from steers offered grazed grass, grass silage or concentrate-based diets. Journal of Animal Science. 2000;78(11):2849-2855. DOI: 10.2527/2000.78112849x

[47] Dugan MER, Kramer JKG, Robertson WM, Meadus WJ, Aldai N, Rolland DC. Comparing subcutaneous adipose tissue in beef and muskox with emphasis on trans 18:1 and conjugated linoleic acids. Lipids. 2007;42(6):509-518. DOI: 10.1007/s11745-007-3051-7

[48] Aldai N, Nájera AI, Dugan MER, Celaya R, Osoro K. Characterisation of intramuscular, intermuscular and subcutaneous adipose tissues in yearling bulls of different genetic groups. Meat Science. 2007;76(4):682-691. DOI: 10.1016/j.meatsci.2007.02.008

[49] French P, O'riordan EG, Monahan FJ, Caffrey PJ, Moloney AP. Fatty acid composition of intra-muscular triacylglycerols of steers fed autumn grass and concentrates. Livestock Production Science. 2003;81(2):307-317. DOI: 10.2527/2000.78112849x

[50] Freitas AK. Características da carcaça, da carne e perfil dos ácidos graxos de novilhos Nelore inteiros ou castrados em duas idades [thesis]. Goiânia: Federal University of Goias; 2006

[51] Frank D, Ball A, Hughes J, Krishnamurthy R, Piyasiri U, Stark J, Watkins P, Warner R. Sensory and flavor chemistry characteristics of Australian beef: Influence of intramuscular fat, feed and breed. Journal of Agricultural and Food Chemistry. 2016;64(21):42994311. DOI: $10.1021 /$ acs.jafc.6b00160 
[52] Hwang YH, Joo ST. Fatty acid profiles of ten muscles from high and low marbled (quality grade $1++$ and 2) Hanwoo beef. Korean Journal for Food Science of Animal Resources. 2016;36:679-688. DOI: 10.5851/kosfa.2016.36.5.679

[53] Hwang YH, Joo ST. Fatty acid profiles, meat quality and sensory palatability of grainfed and grass-fed beef from Hanwoo, American and Australian crossbred cattle. Korean Journal for Food Science of Animal Resources. 2017;37:153-161. DOI: 10.5851/ kosfa.2017.37.2.153

[54] Bingham SA, Hughes R, Cross AJ. Effect of white versus red meat on endogenous $\mathrm{N}$-nitrosation in the human colon and further evidence of a dose response. The Journal of Nutrition. 2002;132(11):3522S-3525S

[55] Sinclair AJ. Dietary fat and cardiovascular disease: The significance of recent developments for the food industry. Food Australia. 1993;45:226

[56] Kwon HN, Choi CB. Comparison of lipid content and monounsaturated fatty acid composition of beef by country of origin and marbling score. Journal of the Korean Society of Food Science and Nutrition. 2015;44:1806-1812

[57] Melton LM, Amiri W, Backus DR. Flavor and chemical characteristics of ground beef from grass-forage-grain- and grain-finished steers. Journal of Animal Science. 1982;55(1):77-87

[58] Rudel L, Park S, Sawyer K. Compared with dietary monounsaturated and saturated fat, polyunsaturated fat protects African green monkeys from coronary artery atherosclerosis. Arteriosclerosis, Thrombosis, and Vascular Biology. 1995;15:2101-2110. DOI: 10.1161/01.ATV.15.12.2101

[59] Smith SB. The animal fatty acid synthase: One gene, one polypeptide, seven enzymes. FASEB Journal. 1994;8:1248-1259

[60] Calder PC, Albers R, Antoine JM, Blum S, Bourdet-Sicard R, Ferns GA, Folkerts G, Friedmann PS, Frost GS, Guarner F, Løvik M, Macfarlane S, Meyer PD, M'Rabet L, Serafini M, van Eden W, van Loo J, Vas Dias W, Vidry S, Winklhofer-Roob BM, Zhao J. Inflammatory disease processes and interactions with nutrition. British Journal of Nutrition. 2009;101:1-45. DOI: 10.1017/S0007114509377867

[61] Nordic Council of Ministers. Nordic nutrition recommendations. Scandinavian Journal of Nutrition. 1996;40:161-165

[62] Schaefer EJ. Lipoproteins, nutrition, and heart disease. The American Journal of Clinical Nutrition. 2002;75:191-212

[63] Scientific Review Committee. Nutrition recommendations. Ottawa: Canadian Government Publishing Centre, Supply and Services Canada. 1990

[64] Laaksonen DE, Nyyssönen K, Niskanen L, Rissanen TH, Salonen JT. Prediction of cardiovascular mortality in middle-aged men by dietary and serum linoleic and polyunsaturated fatty acids. Archives of Internal Medicine. 2005;165(2):193-199. DOI: 10.1001/ archinte.165.2.193 
[65] Öhlund I, Hörnell A, Lind T, Hernell O. Dietary fat in infancy should be more focussed on quality than on quantity. European Journal of Clinical Nutrition. 2007;62(9):1058-1054. DOI: $10.1038 /$ sj.ejcn.1602824

[66] Calder P. N-3 polyunsaturated fatty acids, inflammation, and inflammatory diseases. American Journal of Clinical Nutrition. 2006;83:1505S-1519S

[67] Luu NT, Madden J, Calder PC, Grimble RF, Shearman CP, Chan T, Dastur N, Howell WM, Rainger GE, Nash GB. Dietary supplementation with fish oil modifies the ability of human monocytes to induce an inflammatory response. Journal of Nutrition. 2007;137:2769-2774

[68] Bauman DE, Baumgard LH, Corl BA, Griinari JM. Biosynthesis of conjugated linoleic acid in ruminants. Proceedings of the American Society of Animal Science. 1999;7:1-15. DOI: $10.2527 /$ jas2000.77E-Suppl1f

[69] Rainer L, Heiss CJ. Conjugated linoleic acid: Health implications and effects on body composition. Journal of the American Dietetic Association. 2004;104(6):963-968. DOI: 10.1016/j.jada.2004.03.016

[70] Cross AJ, Leitzmann MF, Gail MH, Hollenbeck AR, Schatzkin A, Sinha R. A prospective study of red and processed meat intake in relation to cancer risk. PLoS Medicine. 2007;4(12):e325

[71] Kontogianni MD, Panagiotakos DB, Pitsavos C, Chrysohoou C, Stefanadis C.Relationship between meat intake and the development of acute coronary syndromes: The CARDIO2000 case-control study. European Journal of Clinical Nutrition. 2008;62:171177. DOI: $10.1038 /$ sj.ejcn. 1602713

[72] Micha R, Wallace SK, Mozaffarian D. Red and processed meat consumption and risk of incident coronary heart disease, stroke, and diabetes mellitus. Circulation. 2010;121: 2271-2283. DOI: 10.1161/CIRCULATIONAHA.109.924977

[73] Campbell WW, Tang M. Protein intake, weight loss, and bone mineral density in postmenopausal women. The Journals of Gerontology Series A: Biological Sciences and Medical Sciences. 2010;65A(10):1115-1122. DOI: 10.1093/gerona/glq083

[74] Pan A, Sun Q, Bernstein AM, Schulze MB, Manson JE, Stampfer MJ, Willett WC, Hu FB. Stampfer Red meat consumption and mortality: Results from 2 prospective cohort studies. Archives of Internal Medicine. 2012;172(7):555-563. DOI: 10.1001/archinternmed.2011. 2287

[75] Roussell MA, Hill AM, Gaugler TL, West SG, Heuvel JP, Alaupovic P, Gillies PJ, KrisEtherton PM. Beef in an optimal lean diet study: Effects on lipids, lipoproteins, and apolipoproteins. The American Journal of Clinical Nutrition. 2012;95:9-16. DOI: 10.3945/ ajcn.111.016261

[76] Szterk A, Waszkiewicz-Robak B. Influence of selected quality factors of beef on the profile and the quantity of heterocyclic aromatic amines during processing at high temperature. Meat Science. 2014;96(3):1177-1184. DOI: 10.1016/j.meatsci.2013.11.019 
[77] Oostindjer M, Alexander J, Amdam GV, Andersen G, Bryan NS, Chen D, Corpet DE, De Smet S, Dragsted LO, Haug A, Karlsson AH, Kleter G, de Kok TM, Kulseng B, Milkowski AL, Martin RJ, Pajari AM, Paulsen JE, Pickova J, Rudi K, Sodring M, Weed DL, Egelandsdal B. The role of red and processed meat in colorectal cancer development: A perspective. Meat Science. 2014;97(4):583-596. DOI: 10.1016/j.meatsci.2014.02.011

[78] McAfee AJ, McSorley EM, Cuskelly GJ, Moss BW, Wallace JM, Bonham MP, Fearon AM. FearonRed meat consumption: An overview of the risks and benefits. Meat Science. 2010;84(1):1-13. DOI: 10.1016/j.meatsci.2009.08.029

[79] Senegalhe FBD, Burin PC, Fuzikawa IHS, Penha DS, Leonardo AP. Ácidos Graxos na Carne e Gordura de Ovinos. Enciclopédia Biosfera. Centro Científico Conhecer Goiânia. 2014;10(18):18

[80] Oliveira AC, Silva RR, Oliveira HC, Almeida VVS, Garcia R, Oliveira ULC. Influence of diet, sex and genotype on the lipid profile of sheep meat. Archivos de Zootecnia. 2013;62:57-72

[81] Kouba M, Mourota J. A review of nutritional effects on fat composition of animal products with special emphasis on n-3 polyunsaturated fatty acids. Biochimie. 2011;93(1):13-17. DOI: 10.1016/j.biochi.2010.02.027

[82] Duckett SK, Wagner DG, Yates LD, Dolezal HG, May SG. Effects of time on feed on beef nutrient composition. Journal of Animal Science. 1993;71:2079-2088. DOI: $10.2527 / 1993.7182079 x$

[83] Mueller LF. Sexual Condition Effects on Performance, Carcass Traits and Beef Quality of Feedlot Crossbred Angus x Nellore Cattle [Thesis]. Pirassununga: University of Sao Paulo; 2017

[84] Turk SN, Smith SB. Carcass fatty acid mapping. Meat Science. 2009;81(4):658-663. DOI: 10.1016/j.meatsci.2008.11.005

[85] Smith SB, Kawachi H, Choi CB, Choi CW, Wu G, Sawyer JE. Cellular regulation of bovine intramuscular adipose tissue development and composition. Journal of Animal Science Abstract-Meat Quality: Regulation of Intramuscular fat deposition. 2009;87(14):72-82. DOI: $10.2527 /$ jas.2008-1340

[86] Daley CA, Abbott A, Doyle PS, Nader GA, Larson S. A review of fatty acid profiles and antioxidant content in grass-fed and grain-fed beef. Nutrition Journal. 2010;9(1):9-10. DOI: $10.1186 / 1475-2891-9-10$

[87] Duckett SK, Neel JPS, Fontenot JP, Clapham WM. Effects of winter stocker growth rate and finishing system on: 3 . Tissue proximate, fatty acid, vitamin and cholesterol content. Journal of Animal Science. 2009;87(9):2961-2970. DOI: 10.2527/jas.2009-1850

[88] Lorenzen CL, Golden JW, Martz FA, Grun IU, Ellersieck MR, Gerrish JR, Moore KC. Conjugated linoleic acid content of beef differs by feeding regime and muscle. Meat Science. 2007;75(1):159-167. DOI: 10.1016/j.meatsci.2006.06.025 
[89] Van Elswyk ME, McNeill SH. Impact of grass/forage feeding versus grain finishing on beef nutrients and sensory quality: The U.S. experience. Meat Science. 2014;96:535-540. DOI: 10.1016/j.meatsci.2013.08.010

[90] Cordain L, Watkins BA, Florant GL, Kelher M. Fatty acid analysis of wild ruminant tissues: Evolutionary implications for reducing diet-related chronic disease. European Journal of Clinical Nutrition. 2002;56(3):181. DOI: 10.1038/sj.ejcn.1601307

[91] Ferrinho AM, Nassu RT, Aldai N, Bravo-Lamas L, Furlan MLN, Toda BM, Utembergue BL, Rezende RG, Mueller LF, Furlan JJM, Zanata M, Baldi F, Pereira ASC. Whole cottonseed, vitamin $\mathrm{E}$ and finishing period affect the fatty acid profile and sensory traits of meat products from Nellore cattle. 2018;138:15-22. DOI: 10.1016/j.meatsci.2017.12.002

[92] Díaz MT, Velasco S, Cañeque V, Lauzurica S, Huidobro FR, Pérez C, González J, Manzanares C. Use of concentrate or pasture for fattening lambs and its effect on carcass and meat quality. Small Ruminant Research. 2002;43:257-268. DOI: 10.1016/ S09214488(02)00016-0

[93] Rhee KS. Fatty acids in meats and products. In: Chow CK, editor. Fatty Acids in Fods and their Health Implications. New York: Marcel Dekker; 1992. pp. 65-93

[94] Pelegrini LFV, Pires CC, Kozloski GV, Terra NN, Baggio SR, Campagnol PCB, Galvani DB. Perfil de ácidos graxos da carne de ovelhas de descarte de dois grupos genéticos submetidas a dois sistemas de manejo. Ciência Rural. 2007;37(6):1786-1790

[95] Wood JD, Enser M. Factors influencing fatty acids in meat and the role of antioxidants in improving meat quality. British Journal of Nutrition. 1997;78(1):S49-S60. DOI: 10.1079/ BJN19970134

[96] Morel PCH, Mc Intoshi JC, Janz JAM. Alteration of the fatty acid profile of pork by dietary manipulation. Journal of Animal Science. 2006;19(3):431-437. DOI: 10.5713/ ajas.2006.431

[97] Ajuyah AO, Lee KH, Hardin RT, Sim JS. Changes in the yield and in the fatty acid composition of whole carcass and selected meat portions of broiler chickens fed full-fat oil seeds. Poultry Science. 1991;70(11):2304-2314. DOI: 10.3382/ps.0702304

[98] Lopez-Ferrer S, Baucells MD, Barroeta AC, Grashorn MA. N-3 enrichment of chicken meat. 1 . Use of very long-chain fatty acids in chicken diets and their influence on meat quality: Fish oil. Poultry Science. 2001;80(6):741-752. DOI: 10.1093/ps/80.6.741

[99] Lara LJC, Baiao NC, Aguilar CAL, Cançado MA, Fiuza MA, Ribeiro BRC. Rendimento, composição e teor de ácidos graxos da carcaça de frangos de corte alimentados com diferentes fontes lipídicas. Arquivo Brasileiro de Medicina Veterinária e Zootecnia. 2006;58(1):108-115. DOI: 10.1590/S0102-09352006000100016

[100] Sirri F, Tallarico N, Meluzzi A, Franchini A. Fatty acid composition and productive traits of broiler fed diets containing conjugated linoleic acid. Poultry Science. 2003;82(8): 1356-1361. DOI: $10.1093 / \mathrm{ps} / 82.8 .1356$ 
[101] Suksombat W, Boonmme T, Lounglawan P. Effects of various levels of conjugated linoleic acid supplementation on fatty acid content and carcass composition of broilers. Poultry Science. 2007;86:318-324

[102] Lemos MVA, Chiaia HLJ, Berton MP, Feitosa FLB, Aboujaoude C, Pereira ASC, Albuquerque LG, Ferrinho AM, Mueller LF, Mazalli MR, Furlan JJM, Carvalhero R, Gordo DM, Espigolan R, Duckett SK, Baldi F. Genome-wide association between single nucleotide polymorphisms with beef fatty acid profile in Nellore cattle using the single step procedure. BMC Genomics. 2016;172:13-225. DOI: 10.1186/s12864-016-2511-y

[103] Magalhães AFB, de Camargo GMF, Fernandes GA, Junior GDGM, Tonussi RL, Costa RB, Espigolan R, Silva RMO, Bresolin T, Andrade WBF, Takada L, Feitosa FB, Baldi F, Carvalheiro R, Chardulo LAL, Albuquerque LG. Genome-wide association study of meat quality traits in Nellore cattle. PLoS One. 2016;11(6):e0157845. DOI: 10.1371/ journal.pone.0157845

[104] Feitosa FLB, Olivieri BF, Aboujaoude C, Pereira ASC, Lemos MVA, Chiaia HLJ, Berton MP, Peripolli E, Ferrinho AM, Mueller LF, Mazalli MR, Albuquerque LG, Oliveira HN, Tonhati H, Espigolan R, Tonussi RL, Silva RMO, Gordo DGM, Magalhães AFB, Aguilar I, Baldi F. Genetic correlation estimates between beef fatty acid profile with meat and carcass traits in Nellore cattle finished in feedlot. Journal of Applied Genetics. 2017;58(1):123-132. DOI: 10.1007/s13353-016-0360-7

[105] Inoue K, Kobayashi M, Shoji N, Kato K. Genetic parameters for fatty acid composition and feed efficiency traits in Japanese black cattle. Animal. 2011;5(7):987-994. DOI: 10.1017/S1751731111000012

[106] Jeremiah LE, Dugan ME, Aalhus JL, Gibson LL. Assessment of the relationship between chemical components and palatability of major beef muscles and muscle groups. Meat Science. 2003;65(3):1013-1019. DOI: 10.1016/S0309-1740(02)00309-1

[107] Wood JD. Fat deposition and the quality of fat tissue in meat animals. In: Wiseman J, editor. Fats in Animal Nutrition. 37th ed. London: Butterworths; 1984. pp. 407-435

[108] Domínguez R, Gómez M, Fonseca S, Lorenzo JM. Effect of different cooking methods on lipid oxidation and formation of volatile compounds in foal meat. Meat Science. 2014;97:223-230. DOI: 10.1016/j.meatsci.2014.01.023

[109] Mottram DS. Flavour formation in meat and meat products: A review. Food Chemistry. 1998;62(4):415-424. DOI: 10.1016/S0308-8146(98)00076-4

[110] Volden J, Bjelanovic M, Vogt G, Slinde E, Skaugen M, Nordvi B, Egelandsdal B. Oxidation progress in an emulsion made from metmyoglobin and different triacylglycerols. Food Chemistry. 2011;128(4):854-863. DOI: 10.1016/j.foodchem.2011.03.106

[111] Nieto G, Banon S, Garrido MD. Effect of supplementing ewes diet with thyme (Thymus zygis spp. gracilis) leaves on the lipid oxidation of cooked lamb meat. Food Chemistry. 2011;125:1147-1152. DOI: 10.1016/j.foodchem.2010.09.090 
[112] Li YF, Liu SM. Reducing lipid peroxidation for improving colour stability of beef and lamb: On-farm considerations. Journal of the Science of Food and Agriculture. 2012;92(4):719-726. DOI: 10.1002/jsfa.4715

[113] Renerre M, Deker E, Faustman C, Lopez-Bote CJ. Oxidative processes and myoglobin. In: Decker EA, Faustam C, Lopez-Bote CJ, editors. Antioxidants in Muscle Foods. New York: John Wiley; 2000. pp. 113-133

[114] Yang A, Brewster MJ, Lanari MC, Tume RK. Effect of vitamin E supplementation on $\alpha$-tocopherol and $\beta$-kerotene concentrations in tissues from pasture-and grain-fed cattle. Meat Science. 2002;60(1):35-40

[115] Warren HE, Scollan ND, Hallett K, Enser M, Richardson, RI, Nute GR, Wood JD. The effects of breed and diet on the lipid composition and quality of bovine muscle. In: Proceedings of the 48th Congress of Meat Science and Technology ICoMST; 25-30 August 2002; Rome; 2002. pp. 370-371

[116] Kasapidou E, Wood JD, Sinclair LD, Wilkinson RG, Enser M. Diet and vitamin E metabolism in lambs: Effects of dietary supplementation on meat quality. In: Proceedings of the 47th Congress of Meat Science and Technology; 2001. p. 42-43

[117] Corbin CH, O'Quinn TG, Garmyn AJ, Legako JF, Hunt MR, Dinh TT, Rathmann RJ, Brooks JC, Miller MF. Sensory evaluation of tender beef strip loin steaks of varying marbling levels and quality treatments. Meat Science. 2015;100:24-31. DOI: 10.1016/j. meatsci.2014.09.009

[118] Hunt MR, Garmyn AJ, O'Quinn TG, Corbin CH, Legako JF, Rathmann RJ, Miller MF. Consumer assessment of beef palatability from four beef muscles from USDA choice and select graded carcasses. Meat Science. 2014;98(1):1-8. DOI: 10.1016/j.meatsci.2016.02.010

[119] Legako JF, Dinh TTN, Miller MF, Adhikari K, Brooks JC. Consumer palatability scores, sensory descriptive attributes, and volatile compounds of grilled beef steaks from three USDA quality grades. Meat Science. 2016;112:77-85. DOI: 10.1016/j.meatsci.2015.10.018

[120] Jung EY, Hwang YH, Joo ST. Chemical components and meat quality traits related to palatability of ten primal cuts from Hanwoo carcasses. Korean Journal for Food Science of Animal Resources. 2015;35(6):859-866. DOI: 10.5851/kosfa.2015.35.6.859

[121] Lee SH, Cho YM, Lee SH, Kim BS, Kim NK, Choy YH, Kim KH, Yoon D, Im SK, Oh SJ, Park EW. Identification of marbling-related candidate genes in M. Longissimus dorsi of high- and low marbled Hanwoo (Korean native cattle) steers. BMB Reports. 2008;41(12):846-851 



\section{Section 3}

Strategies to Improve Meat Quality 



\title{
New Nutritional Strategies for Improving the Quality of Meat
}

\author{
Akbar Taghizadeh and Jamal Seifdavati \\ Additional information is available at the end of the chapter \\ http://dx.doi.org/10.5772/intechopen.78041
}

\begin{abstract}
Few studies of using locally legume grains in lamb nutrition have been studied that their use had no negative impact on meat quality such as fatty acid composition. One of the strategies of increasing functional food availability is to increase polyunsaturated fatty acids, especially the $\omega-3$ series, conjugated linoleic acid (CLA) level and reduce saturated fatty acids in animal products. The CLA isomers appear to be concentrated in intramuscular and subcutaneous fat of meat ruminants and the concentration of c9, t11-CLA being greater than the concentration of $\mathrm{t} 10$, and c12-CLA in all tissues. To increase the CLA yield in lamb meat, it is essential to provide lamb an appropriate substrate for the formation of CLA. The provision of source of dietary linoleic acid appears to increase the CLA concentration to the greatest extent. Regarding the recommended daily intake for the appreciation of health benefits in humans $(3500 \mathrm{mg} / \mathrm{d})$, this amount of CLA supplied to meat lamb will partially provide the CLA requirement for everyone under certain conditions; deposition of CLA in the tissues using the provision of modest amounts of locally legume grains is more conducive to CLA synthesis rather than high levels of grain.
\end{abstract}

Keywords: conjugated linoleic acid, local legume grains, meat quality, ruminants, nutrition manipulation, ruminal biohydrogenation

\section{Introduction}

The protein sources form the largest and most cost-effective part of animal feed, and large quantities of these resources are exported annually for use in animal feed production. Not only does this impose a heavy currency burden on the country, it also causes a lot of problems, in which case the quality of the purchased materials, the distances, transportation problems and the probability of their pollution can be pointed out [1]. Therefore, recognizing 
locally feedstuffs and replacing them with imported food sources have a significant contribution to economic self-sufficiency. The leguminous family is widely distributed globally, so that various species of chickling vetch are present in the Canary Islands, Germany, East Asia, Nepal, China, the Middle East, North Africa, southern Europe, North America and the Mediterranean, with moderate climates and moderate rainfall as a source of plant protein for animal nutrition [2].

In recent years, the limitations in the use of animal by-products, such as meat meal due to government regulations, and consumer demand have led to an increase in the use of plant protein sources. Soybean meal is the main plant protein source used in animal feeding and it is largely imported from Brazil, which has recently been questioned. In addition, in the livestock feeds industry, all efforts are made to reduce feed and feed costs; therefore, an important objective of world farmers has been to increase the use of plant protein sources preferably from local feedstuffs. Few studies of using locally legume grains in lamb nutrition have been studied. Several reports seemed to suggest that their use had no negative impact on meat quality such as fatty acid composition [3,4]. Locally produced legumes as alternative protein sources in the diets of ruminants are commonly used worldwide like peas, field beans, types of vetch and rapeseed. Types of vetch, such as bitter vetch (Vicia ervilia L.), common vetch (Vicia sativa L.) and chickling vetch (Lathyrus sativus L.) grains, are the legume seeds available in the Mediterranean and Western Asia areas and especially in the west-north area of Iran and are comparatively cheap despite its relatively high nutritional value. One of the strategies of increasing functional food availability is to increase polyunsaturated fatty acids, especially the $\omega-3$ series, conjugated linoleic acid (c9,t11-CLA) level and reduce saturated fatty acids in animal products $[4,5]$. Although there is a vast amount of literature available about the CLA content of milk, a few research trials focusing on the CLA content of meat are limited. The CLA isomers appear to be concentrated in the intramuscular and subcutaneous fat of meat ruminants and the concentration of $\mathrm{c} 9$, $\mathrm{t} 11$-CLA being greater than the concentration of $\mathrm{t} 10$, c12-CLA in all tissues, but the proportion of the latter CLA isomer is greater in subcutaneous fat [6]. Of the many isomers identified, the cis-9, trans-11 CLA isomer (rumenic acid) accounts for up to $80-90 \%$ of the total CLA in ruminant products [7]. However, the amount of the CLAs found in milk and meat are small, relative to the recommended daily intake for the appreciation of health benefits in humans, which is $3500 \mathrm{mg} / \mathrm{d}$ [6]. There is little data available on the effects of feeding types of vetch grains on lamb intramuscular fatty acid composition. The objective of the present chapter is to evaluate the effect of totally replacing dietary soybean meal and nutrition manipulation of the diet of the livestock to produce high-quality and healthy meat.

\section{Nutrition manipulation for the production of high-quality and healthy meat}

New nutritional strategies for feeding livestock and poultry focus on the increase of unsaturated fatty acids (especially $\mathrm{n}-3$ ) and conjugated linoleic fatty acids and the reduction of saturated fatty acids in animal food products $[5,8]$. To increase the CLA in animal meat, it is essential to provide a suitable base for its formation. Therefore, the inclusion of the source of 
linoleic acid in the ruminant animal diet will be most effective in increasing the concentration of CLA in meat products. Forage foods such as grasses or legumes (alfalfa) are suitable for facilitating the accumulation of CLA and increasing the precipitate and forming it in the tissue of the animals. Therefore, the use of plant sources such as plants in the marine ecosystem and dry areas is one of the first and most important sources of unsaturated fatty acids. Aquatic plants have a special ability to produce fatty acids (18:3n-3), which are the building blocks for the production, refinement and nonsaturation of a series of fatty acids, which ultimately produce docosahexaenoic acid and eicosapentaenoic acid. These two fatty acids are consumed by fish from aquatic plants and can be used to produce a wide variety of fatty acids, especially in fish oil, in fish tissues [5]. Plant sources and dry forages such as clover have a high proportion of unsaturated fatty acids (75-50\%), such as alpha linoleic acid, which can be considered as a suitable substitute for the supply of fatty acid in some regions. However, the transfer of this type of fatty acids in ruminant meat depends on two important processes for increasing the level of these fatty acids in fodder (resulting in the animal) and reducing the amount of ruminal bovine fermentation [5]. However, providing a moderate amount of granular material in the diet concentrate instead of high levels leads to more CLA synthesis. Specific breeds of cattle tend to have more fat storage in the muscle and more CLA in the adipose tissue that is suitable for offering to the consumer. CLA levels of muscle can be increased by increasing the consumption of food items such as fresh fodder, silage, rangeland nutrition and the use of vegetable oils and fish oils, all of which have high levels of linoleic acid [9]. The production of CLA in the ruminant tissue is such that in the pathway of unsaturated fatty acid biosynthesis, the increase in the activity of the delta-9-dosacharase enzyme occurs and ultimately leads to the production of trans-vaccenic acid (Figure 1), which is the acid of the domestic production source; CLA is in the tissue, so that a linear relationship is obtained between the concentration of CLA and trans-vaccenic acid [9]. According to researchers (Table 1), CLA levels in beef ranged from 2.1 to $5.12 \mathrm{mg} / \mathrm{g}$ of fat [10].

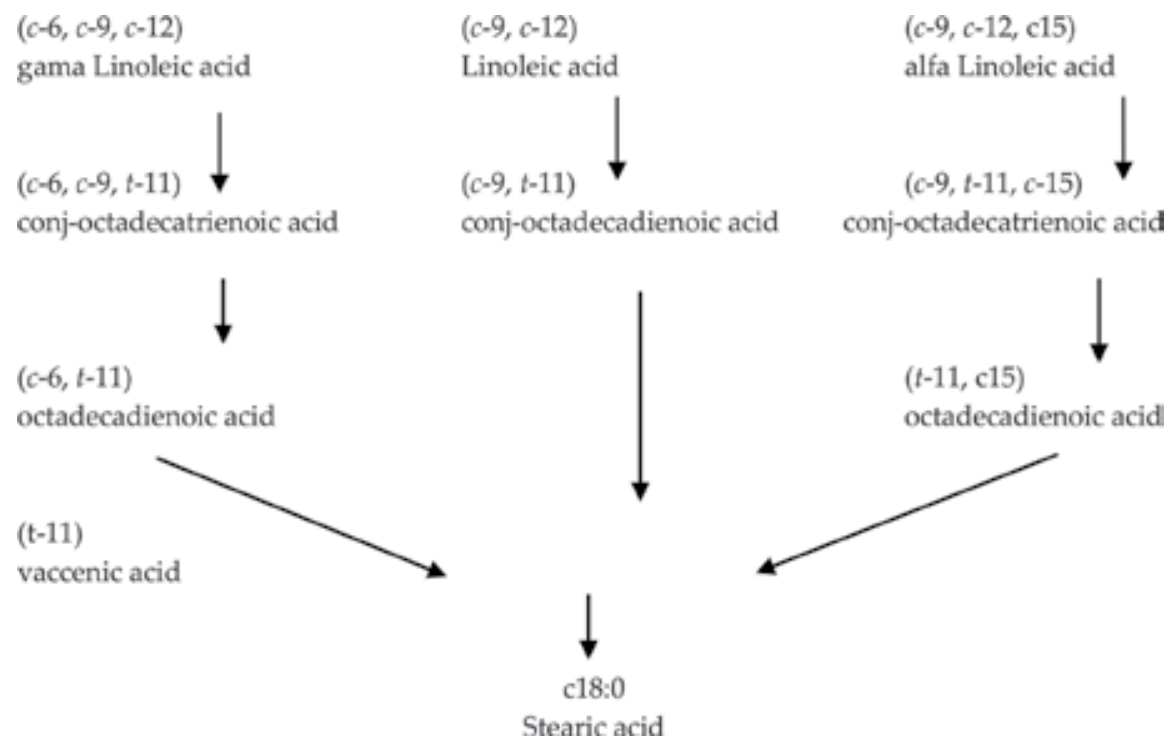

Figure 1. The major route of 18-carbon unsaturated fatty acid biohydrogenation [11]. 
These researchers have identified the variation in the concentration of CLA in beef, depending on the system used and the diet. In these reports, the factors affecting the content of CLA in beef have been compared with pasture forage and that the diet contains oil or whole grains, and even the composition of the fatty acid content of the grains and the ratio of the concentrate to the forage are also evaluated. Lanza et al. [3] in their research showed that the replacement of a variety of legumes with soybean meal and corn grain significantly increases the CLA in lamb meat. Scerra et al. [4] in their research examined the effects of some legume seeds on the composition of fatty acids and intramuscular CLA and showed that feeding some legumes over soybean meal saved omega 3, omega 6 and CLA fatty acids in muscle tissue. Abdollah et al. [12] in their study showed that the replacement of beet seed at different levels of $0,5,10$ and $15 \%$ with soybean meal did not affect the characteristics, carcass traits and performance of lambs and it has been replaced without negative effects and has reduced the cost of the diet. At the $10 \%$ level, daily gain was higher than other levels and control group. The amount of crude protein, NDF, ADF and crude fat was estimated to be 23.1, 21.3, 6.9 and $1.6 \%$, respectively, and researchers have proposed a $10 \%$ level for replacing soybean meal. In the study by Gül et al. [13] the authors used different levels of vetch (0,15 and 25\%) in the diet of avocado lambs and found that in 60 days of the feeding period, the daily gain and feed conversion ratio was $1.716,0.26$ and $6.06 \mathrm{~kg}$ for the level of 0 and $1.756,0.28$ and $6.27 \mathrm{~kg}$ for the level of $15 \%$ and $1.806,0.29$ and $6.23 \mathrm{~kg}$ for the level of $25 \%$ ration lambs. The growth traits, carcass quality and meat quality were approximately the same among treatments, and supplementation of up to $25 \%$ of levels of vetch did not have a significant effect on fattening performance and consumable carcass parts. However numerical improvement was observed in the food conversion ratio.

\begin{tabular}{lll}
\hline Diets & Country breeding system & CLA levels \\
\hline Barley grain $(800 \mathrm{~g} / \mathrm{kg}$ diet $)$ & Canada & $1.7-1.8$ \\
Grass silage and concentrate & England & $3.2-8.0$ \\
Corn grain $(820 \mathrm{~g} / \mathrm{kg}$ of diet $)$ & America & $3.9-4.9$ \\
Grain materials & America & 5.1 \\
Concentrate & Japan & 3.4 \\
Grass hey & America & 7.4 \\
Grass hey & Australia & $2.3-12.5$ \\
Grass hey & Ireland & $3.7-10.8$ \\
Corn and extruded soybean seeds & America & $6.6-7.8$ \\
Pasture forage & America & $3.5-5.6$ \\
Fattening diet & America & $2.9-3.2$ \\
Fattening diet and soybeans seeds & America & $3.2-3.6$ \\
\hline
\end{tabular}

As Ref. [10].

Table 1. CLA levels in cattle meat based on various breeding and feeding systems (mg/g fat). 


\subsection{Chemical composition and fatty acid composition of meat}

The results of the chemical composition of the meat samples are reported in findings by Seifdavati and Taghizadeh [14]. The chemical composition of lamb samples fed with different diets showed a significant difference in crude fat and crude protein $(\mathrm{P}<0.01)$. Unlike crude fats, the raw protein content of lamb meat was higher in soybean meal diet and slightly higher than in other groups. Although the crude protein content of common vetch was higher than the rest of the seeds, the lower carcase protein could be due to its low digestibility of undigested protein in the rumen, which is based on the results of digestion intestinal experiments from the methods of Gargallo et al. [15] and McNiven et al. [16], (for more details, refer to the references $[17,18]$. However, there was no increase in the digestible protein content of the total gastrointestinal tract between the tested samples either in their raw state or autoclaved, except for common vetch grain. Even with the autoclave of the common vetch grain, its protein was too protected and was not digested. According to the findings of Seifdavati and Taghizadeh [14], the composition of their experimental diets containing bitter vetch seed and soybean meal, had higher C16: and C18:0 fatty acids compared to the diets of common vetch group and chickling vetch group. The diets of common vetch and chickling vetch group were rich in linoleic (C18:2) and linolenic (C18:3) as essential fatty acids, compared to bitter vetch diets and soybean meal diets. However, the total of these two fatty acids was in all their experimental diets ranging from 56.6 to 57.05 grams per gram of methylated fatty acids. The results according to Seifdavati and Taghizadeh [14] among the saturated fatty acids showed a significant difference in the C16:0 content of the meat samples of the groups and soybean meal group was higher in lamb meat group $(\mathrm{P}<0.05)$. Also, among the soybean meal groups, the level of palmitic acid C16:0 in lamb meat was higher than soybean meal $(\mathrm{P}<0.01)$. The most abundant fatty acid in meat was oleic acid among legumes and its amount was significantly different between treatments $(\mathrm{P}<0.01)$. Linolenic acid was higher in common vetch group lamb meat than in dietary containing bitter vetch seed, chickling vetch seed and soybean meal $(\mathrm{P}<0.05)$. Similar results for this fatty acid were observed by Lanza et al. [3], Wood et al. [8] and Scerra et al. [4] for other legumes used in the dietary concentrate section. Generally, linolenic acid in common vetch group lamb meat was higher than in dietary containing bitter vetch seed, chickling vetch seed and soybean meal group $(\mathrm{P}<0.01)$. Lamb meat in dietary containing chickling vetch showed higher levels of linolenic acid than lamb meat in soybean meal group $(\mathrm{P}<0.01)$. The fatty acid composition of the muscle of the lambs moderately reflects the composition of the fatty acid in the diet. Ruminants, unlike nonruminants, do not store fat in tissues as much as they receive in the diet. This is because ruminal microorganisms hydrolyze glycerides and subsequently cause hydrogen to combine with unsaturated fatty acids derived from dietary feeds $[19,20]$. Therefore, ruminants have more ratios of saturated to unsaturated fatty acids compared to nonruminants. The reduction of palmitic acid and stearic acid in lamb meat with diets containing chickling vetch and common vetch, respectively, compared with other diets, showed the potential of these two diets to reduce harmful effects on health $(\mathrm{P}<0.01)$. These two acids can be responsible for increasing total cholesterol and low-density lipoprotein in the plasma and increasing the risk of human health [5, 20]. In sheep and lamb meats, the ratio of these two fatty acids is more similar. There is a small variation in the ratio of fatty acids present in different body parts of the lamb. An alternative strategy 
to improve health indicators of humans in relation to consumption of lamb meat is reducing the level of stearic acid in the tissue by increasing the activity of the enzyme, stearoyl-CoA desaturase- $\Delta 9$, although the response of the animal to this manipulation is often relatively small [21]. In terms of fatty acid content, sheep meat is rich in saturated and poor fatty acids from unsaturated fatty acids, which is thought to be harmful for humans [21]. Despite the initial hypothesis [22], the effects of dietary lipids on human health, there were some issues and ambiguities in the concepts of saturated fatty acids that led to an increase in blood cholesterol and coronary artery disease. In a meta-analysis of Hunter et al. [23] on available scientific documentation from 2000 onwards, it resulted in a systematic review of all previous findings on the concepts of saturated fatty acids. The researchers, in a review with contributions from scientists, focused on the topic that the effect of stearic acid as saturated fatty acid on the risk of vascular disease in the heart depends on the fact that this fatty acid is to be replaced with other saturated fatty acids, trans-fatty acids, fatty acids with a double bond and fatty acids with multiple bonds or with sugary substances. One of the goals and main concern of advanced livestock nutrition research is the study of the possible nutritional manipulation of fatty acid composition of the lamb meat to reduce the concentration of saturated fatty acids and increase the concentration of fatty acids (C18:1, C18:2, C18:3), as cholesterol-lowering serum [20, 21]. However, in the study by Seifdavati and Taghizadeh [14], the concentration of palmitic saturated fatty acid in soybean and bitter vetch group meat was higher than other experimental groups $(\mathrm{P}<0.01)$. The higher levels of these two fatty acids (palmitic and stearic acid) in the soybean and bitter vetch group meat can be attributed to the higher levels of these two fatty acids in their diets than those of diets containing chickling vetch and common vetch. The level of oleic fatty acid was lower in raw chickling vetch group than in other experimental groups. The amount of oleic fatty acid in the intramuscular fat was higher than that of the ration levels in the meat of all groups. Fortunately, farm animal cells are capable of synthesizing oleic acid and its derivatives from stearic acid. Oleic acid is obtained by unsaturation or loss of hydrogen in stearic acid. In farm animals especially ruminants, secretion of the $\Delta 9$-desaturase enzyme make stearic acid easily into oleic acid [24]. But linoleic acid in lamb fat was much less than its dietary fat [14]. This indicates that biohydrogenation is a major part of the rumen [25]. Larger amounts of linoleic acid in the fat of lamb in the chickling vetch group are likely to correlate with the high level of this acid in the chickling vetch group compared to the rest of the group. Among the remaining groups, the amount of linoleic acid in the fat of lamb meat was higher than soybean meal group. The internal biosynthesis of linolenic acid is shown in the studies of Zhou and Nilsson [26]. This acid is a precursor to omega-3 fatty acids that have a wide range of biological activities with beneficial effects on human health [27-29]. Linolenic acid level, similar to linoleic acid in lamb fat, was less than its dietary fat, indicating a major part of its transformation and hydrogenation in the rumen [25].

\subsection{CLA of lamb's muscle}

The CLA values in the muscles of the lambs in different groups are shown in findings of Seifdavati et al. [17]. According to these findings in the lamb meat samples of the diet group consisting of common vetch seed, chickling vetch seed, bitter vetch seed and soybean meal, the amount of CLA was 2.23, 1.41, 1.94 and $1.15 \mathrm{~g}$ per methylated fatty acid, respectively, and 
so CLA in the diet group containing common vetch seed was significantly more than lamb meat of others dietary groups $(\mathrm{P}<0.01)$. However, except for the soybean meal group, CLA levels of meat were not significantly different between lambs fed with diets containing raw legumes and processed with autoclave moist heat $(\mathrm{P}<0.01)$. It is likely that the difference between the dietary groups of the contents of the tested legumes and the soybean meal composition group (control) is related to the specific effect of common vetch, chickling vetch, bitter vetch seeds in expressing the gene and increasing the activity of the $\Delta 9$-desaturase enzyme for the production of CLA precursors. Priolo et al. [30] showed that farm animals, especially ruminants, by secreting this enzyme easily convert stearic acid into oleic acid. Priolo et al. [24] found that, by replacing some kind of legumes, the CLA increased in the meat of lambs than soybean meal in lamb diet. The findings of Seifdavati et al. [17] are consistent with the results of Priolo et al. [24]. French et al. [31] reported that CLA levels of calf meat fed with different levels of concentrate and basic forage were different. In this study, the amount of CLA in meat were in the diet of the group ( $4 \mathrm{~kg}$ of concentrate + free forage), $0.47 \mathrm{~g}$ per $100 \mathrm{~g}$ of muscle fatty acid, diet group ( $8 \mathrm{~kg}$ of concentrate $+1 \mathrm{~kg}$ of hey), $0.37 \mathrm{~g}$ per $100 \mathrm{~g}$ of muscle fatty acid, diet group ( $6 \mathrm{~kg}$ of grass fodder $+5 \mathrm{~kg}$ of concentrate), $0.54 \mathrm{~g}$ per $100 \mathrm{~g}$ of muscle fatty acid), diet group (12 kg of grass fodder $+2.5 \mathrm{~kg}$ of concentrate), $0.66 \mathrm{~g}$ per $100 \mathrm{~g}$ of muscle fatty acid and finally diet group (Only $22 \mathrm{~kg}$ of grass fodder), $1.08 \mathrm{~g}$ per $100 \mathrm{~g}$ of muscle fatty acid. Franch et al. [31] concluded that by increasing the level of concentrate, the level of CLA in meat was reduced. De La Torre et al. [32] in a report showed that the base ration and supplementation with oily grains were one of the effective ways to increase the amount of CLA in meat and the use of flaxseed (22 to 36\%) in the ration was increased the amount of CLA meat. The researchers explained that the basic forage with concentrates, especially whole grains in the ration of livestock, reduced the severity of the unsaturated fatty acid dehydrogenation in the rumen, and this resulted in the production of optimal trans-vaccenic acid for the synthesis of CLA and its accumulation in meat. McNiven et al. [20] showed that the use of toasted soybean seed instead of its crude soybean seed in feeding calves with base ration did not have an effect on the amount of CLA in meat, and its rate in this report was $0.32-0.35 \mathrm{~g}$ per $100 \mathrm{~g}$ of fatty acid muscle. Despite the negative effects of rumen metabolism on the intramuscular fat structure of the livestock, the process of biohydrogenation is often carried out incompletely and produces several intermediates that affect human health. One of these compounds is the rumenic acid known as CLA (one of the linoleic acid isomers). Increasing interest in this compound has been attributed to anticancer, coronary heart disease and anti-hyperglycemia and prevents lipid accumulation in the body [20,33,34]. In animal experiments, CLA has been shown to inhibit cancer, diabetes and atherosclerosis [35-38]. In addition, McGuire and his colleagues [39] reviewed some of the potential effects of CLA on human health. These researchers have recommended that the increase in the accumulation of CLA in human consumption is realized by manipulation of the dietary intake of ruminants, especially sheep, for the purpose of enriching meat, in order to show the beneficial effects of this compound on health. In the study of Seifdavati et al. [17], CLA levels in meat from lamb fed with the diet group containing common vetch seed were higher than soybean meal group $(\mathrm{P}<0.01)$ and numerically higher than chickling vetch and bitter vetch seed groups. This can be attributed to a high level of linoleic acid in the content of common vetch seed diet. This fact is shown in the report by Scerra et al. [4], which investigated the effects of some legume seeds on intramuscular CLA, 
in their study. So these researchers found that the higher intracellular CLA in peas seed with $0.45 \mathrm{~g}$ per $100 \mathrm{~g}$ of methylated fatty acid compared with soybean meal $(0.20 \mathrm{~g}$ per $100 \mathrm{~g}$ of methylated fatty acid) was associated with high levels of linoleic acid in the pea seed diet. As mentioned earlier, in nonruminants, the fatty acid structure of their meat is similar to the structure of fatty acid in the diet, both in terms of accumulation and in terms of its secretion and biosynthetics [40]. However, this is a beneficial and similar effect in ruminants by manipulating and benefiting from the biohydrogenation incomplete process of ruminal metabolism on the dietary fat content [41]. However, several studies have shown the difference in the structure of dietary fatty acids with ruminant body tissues (milk or meat) [42-44]. In the study of Seifdavati et al. [17], CLA levels in lamb meat were two to three times higher than those of other researchers, as reviewed by Khanal and Olson [45] and McNiven et al. [20]. The results of Seifdavati et al. [17], also coincided with the findings of Tilak et al. [46], Valvo et al. [47] and Lanza et al. [3]. In the study of Lanza et al. [3] reported that the use of pea grain and horse beans grain instead of soybean meal in the diet of lamb fattening did not change the amount of CLA in meat of lambs and its values for all treatments ranged from 0.78 to $0.93 \mathrm{~g}$ per $100 \mathrm{~g}$ of methylated fatty acids. Not only differences in CLA content of products in an animal but also among species have been reported and received. In general, CLA levels are higher in ruminants compared to nonruminants [6]. Differences in the total amount of CLA in lamb meat in the experiment of Seifdavati et al. [17], with other reports, can be due to several factors such as nutrition from pasture forage as compared to intensive feeding of the high grain content of rations, the nature of nutrient content of dietary concentrate (having intact and complete oily seeds), the composition of fatty acid supplementation, the proportion of concentrate and silage versus hay, seasonal differences, genetics and animal breed, the type and nature of the seed and the breeding system [6, 46]. In the study of Seifdavati et al. [17], wetheating autoclave treatments of legume grains replacing soybean meal in lamb's diet had no effect on the results of CLA levels of lamb meat. This can be due to the inherent nature of the seeds and the difference in the processing method. The findings of McNiven et al. [20] regarding the effect of soybean heat treatment on CLA in meat contradicted Seifdavati et al. [17] conclusion. In contrast to McNeven et al. [20] findings and in accordance with the results of Seifdavati et al. [17] experiment, Mohammed et al. [48] study showed that the content of trans-fatty acid (C18:1) and CLA isomer of cow milk has a strong effect from the type and nature of the source of grain compared to the processing method, and these researchers have shown that intrinsic factors in the type of grain such as anti-nutritional factors like tannin are responsible for the difference and may not be affected by the processing method. Researchers have shown that tannin content of legume or legume seeds (such as common vetch, chickling vetch and bitter vetch seeds) causes the accumulation of trans-vaccenic acid in rumen in both cases, using the live animal and the laboratory methods $[49,50]$. Because tannins have the ability to inhibit trans-vaccenic acid in rumen converting bacteria to stearic acid or, in other words, to reduce the action of biodehydrogenation by inhibiting the activity of mentioned bacteria $[49,50]$, as a result, this process of CLA production increases as an intermediate product of this route $[49,50]$. Despite this, Vasta et al. [51] showed that the CLA of tannin (certainly in low-to-moderate concentrations) is less effective than vaccenic acid, which suggests the fact that CLA is also produced and synthesized in the muscle as endogenous. In the experiment of Vasta et al. [51], CLA levels in the control diet muscle (dried alfalfa with concentrate) were $0.73 \mathrm{~g}$ per $100 \mathrm{~g}$ of methylated fatty acids, and the diet containing tannin-rich carob pulp treated with and without polyethylene glycol was 0.63 and $0.48 \mathrm{~g}$ per $100 \mathrm{~g}$ of 
methylated fatty acid. Findings of Di La Torre et al. [32], Franch et al. [31] and Priolo et al. [24] and in results of Seifdavati et al. [17], lambs fed with whole legumes grains and with alfalfa hay as total mixed ration (TMR) and full oily seeds (more fatty common vetch seed compared to the rest of the seeds) mixed with alfalfa (especially the inclusion of common vetch seed instead of soybean meal) showed that it caused and led to an increase in CLA meat from 1.15 $\mathrm{g}$ per $100 \mathrm{~g}$ of methylated fatty acid (soybean meal ration) to $2.23 \mathrm{~g}$ per $100 \mathrm{~g}$ of methylated fatty acid (diet of common vetch seed). Based on the per capita consumption of sheep meat at $7.6 \mathrm{~kg}$ per year in Iran, $37 \mathrm{~g}$ a day is consumed [52]. According to these figures, based on the daily requirement of humans ( $3500 \mathrm{mg}$ of CLA) and the amount CLA of sheep meat intake per day, it will range from 1.8 to $7 \mathrm{mg}$ and depending on the marble fat inside the muscle and supplementation of diets of lambs with whole oily grains in fattening. The average value of CLA in the muscle fat of sheep in quantitative aspects are not justifiable and can not be interpreted, unless with for enrichment the lamb meat with CLA, it is used appropriate feed in the diet to form CLA. Preferably, these materials should be rich in linoleic acid. The forage in diet with the consolidation and proliferation of CLA productive and storage microorganisms and forage supplementation with medium amounts of full-fat high-grade whole-grain material in comparison with high levels of grains material for lambs leads to more CLA for accumulation in muscle tissue. Taking into consideration that the daily requirement per person $(3500 \mathrm{mg})$ with regard to the CLA for the beneficial effects on health, part of these needs can be achieved by daily consumption of lamb meat and its inclusion in the food pyramid or food basket provided in each household.

\subsection{The use of breeds with an increased capacity to deposit CLA in lambs muscle}

Public health policies recommend population-wide decreases in the consumption of fat, saturated and trans-fatty acids (TFA), and higher intakes of polyunsaturated fatty acids such as increasing in the consumption of the long-chain n-3 polyunsaturated fatty acids (PUFAs), eicosapentaenoic acid (20:5n-3, EPA), and docosahexaenoic acid (22:6n-3, DHA) [54]. Another potential pathway to increase PUFAs in ruminant tissues is to utilize breeds with an increased ability to deposit these fatty acids or deposit n-3 PUFAs in preference to those of the n-6 fatty acid series [55]. According to findings of Wachira et al. [56] Suffolk and Soay lambs contained more $\alpha$-linolenic acid (ALA) than the Friesland lambs, and Soay lambs had higher intramuscular levels for all the major n-6 PUFAs and CLA than Suffolk or Friesland lambs. The LA and ALA were higher in the Suffolk $\times$ Lleyn lambs than Scottish Blackface, as considered in the polar lipids of the semimembranosus muscle [54]. Lambs from Merino dams had about $2 \mathrm{mg} / 100 \mathrm{~g}$ higher levels of EPA + DHA than lambs from cross-bred dams, when the sire breed was Poll Dorset [57].

\subsection{Protected fat as sources of $n-3$ fatty acids}

Ferreira et al. [58] showed that stearic acid concentration decreased linearly when fish oil replaced soybean oil. Also, vaccenic acid concentration was higher for lamb-fed fat diets versus control diet with a 10:90 of forage to concentrate ratio. In addition, vaccenic acid increased linearly with fish oil inclusion. The conjugated linoleic acid (CLA) C18:2 cis-9, trans-11 showed a higher concentration in the meat of animal-fed diets containing fish oil compared to controlled diet, but it was not affected by soybean oil inclusion. However, if the fat used in the diet is somehow protected from rumen degradation, the result will be doubled, as shown in 
the research that the CLA content of lamb longissimus muscle improved $16.7 \%$ when $86.6 \mathrm{~g}$ of Megalac (as fat protected) per $\mathrm{kg}$ of diet DM was fed for 10 weeks [59]. It is the general opinion that inclusion of protected fat in diet increases the concentration of n-3 and n- 6 fatty acids in muscle in some but not all researches [60, 61]. In these studies (as shown in Table 2), there was a higher amount of corn in the controlled diet as a replacement of protected fat diet and thus more LA [53]. It should also be noted that it is not obvious if the 18:3 shown is $n-3, n-6$ or the sum of both, in the study of Castro et al. [60]. In contradiction with the comment, GómezCortés et al. [62] find the fatty acid composition of lamb muscle with a significant difference among diets containing calcium soap fatty acid (CSFA) compared with extruded linseed for 18:3n-3 ( $\alpha$-linolenic acid, ALA) but with no effect on 18:3n-6 ( $\gamma$-linolenic acid, GLA). A significant difference among diets for the muscle level of ALA and no effect on GLA was found in research [63]. A recent research showed the ALA, EPA, DPA, DHA and the sum of PUFA levels, in IMF, were higher in lambs fed with extruded linseed than CSFA of palm oil [62]. This could be because of the higher level of ALA in extruded linseed than in calcium soap of palm oil (as shown in Table 2), which is the precursor of the n-3 long-chain PUFA.

\begin{tabular}{|c|c|c|c|c|}
\hline & Unit & Oleic & Linoleic & Linolenic \\
\hline \multicolumn{5}{|l|}{ Concentrate } \\
\hline Soybean & $\%$ & 23.3 & 52.2 & 5.6 \\
\hline Soybean & $\%$ & 23.1 & 54.5 & 8 \\
\hline Corn & $\%$ & 37 & 47.2 & 1.3 \\
\hline Sunflower & $\%$ & 45.4 & 46 & 0.1 \\
\hline Sunflower & $\%$ & 61.8 & 27.9 & 0.1 \\
\hline Mustard & $\%$ & 38.2 & 25.3 & 11.3 \\
\hline Rapeseed & $\%$ & 46.8 & 19.5 & 8.7 \\
\hline Canola & $\%$ & 61.8 & 18.7 & 10.4 \\
\hline Linseed & $\%$ & 18.5 & 17.3 & 53.2 \\
\hline Extruded linseed & $\%$ & 15.1 & 18.2 & 54.3 \\
\hline Protected linseed & $\mathrm{g} / 100 \mathrm{~g}$ & 56.1 & 25 & 7.7 \\
\hline Palm & $\%$ & 41.9 & 11 & - \\
\hline Palm & $\%$ & 18 & 4 & - \\
\hline Palm olein & $\%$ & 49.5 & 11.7 & 0.5 \\
\hline Red palm olein & $\%$ & 44.6 & 10.4 & 0.3 \\
\hline Coconut & $\%$ & 7.2 & 1.7 & - \\
\hline Coconut & $\%$ & 5.8 & 1.3 & - \\
\hline Cotton seed & $\%$ & 17 & 53.3 & - \\
\hline Oats & $\mathrm{g} / 100 \mathrm{~g}$ & 38.8 & 38.3 & 1.2 \\
\hline Barley & $\mathrm{g} / 100 \mathrm{~g}$ & 14.2 & 57.8 & 5.4 \\
\hline
\end{tabular}




\begin{tabular}{|c|c|c|c|c|}
\hline & Unit & Oleic & Linoleic & Linolenic \\
\hline Lupins & $\mathrm{g} / 100 \mathrm{~g}$ & 31.3 & 42.1 & 5.2 \\
\hline Flax seeds & $\%$ & 22 & 18.3 & 48.2 \\
\hline \multicolumn{5}{|l|}{ Roughage } \\
\hline Green maize fodder & $\mathrm{g} / 100$ & 4.7 & 17.1 & 38.9 \\
\hline Wheat straw & $\mathrm{g} / 100 \mathrm{~g}$ & 14.9 & - & - \\
\hline Perennial ryegrass & $\mathrm{mg} / \mathrm{g}$ DW & 0.4 & 2.73 & 15 \\
\hline Fresh grass perennial ryegrass & $\%$ & 1.7 & 10.6 & 68.4 \\
\hline Fresh ryegrass & $\mathrm{g} / 100 \mathrm{~g}$ & 1.5 & 12.6 & 55.3 \\
\hline Silage perennial ryegrass & $\%$ & 1.2 & 11.8 & 64.7 \\
\hline Silage ryegrass & $\mathrm{g} / 100 \mathrm{~g}$ & 1.6 & 11.2 & 51.3 \\
\hline Fresh corn (whole plant) & $\mathrm{g} / 100 \mathrm{~g}$ & 16.4 & 47.5 & 12 \\
\hline Silage corn & $\mathrm{g} / 100 \mathrm{~g}$ & 14.4 & 41.4 & 10.6 \\
\hline Lucerne hay & $\%$ & 8 & 24.4 & 23.2 \\
\hline Corn silage & $\%$ & 18.8 & 48.5 & 11.1 \\
\hline \multicolumn{5}{|l|}{ Supplementation } \\
\hline Algae U. lactuca (flour) & $\%$ & 27.4 & 8.3 & 4.4 \\
\hline Algae D. antarctica (leaves) & $\%$ & 25.4 & 10.8 & 3.9 \\
\hline Algae D. antarctica (stem) & $\%$ & 25.8 & 15.7 & 1.1 \\
\hline DHA Gold algae & $\%$ & 0 & 0.01 & 0.1 \\
\hline Protected fat & $\mathrm{g} / 100 \mathrm{~g}$ & 26.4 & 32.7 & 2 \\
\hline Megalac & $\%$ & 34.4 & - & - \\
\hline Calcium soap of palm oil & $\%$ & 9.7 & - & - \\
\hline Fish oil & $\%$ & 25.8 & 3.6 & 1.3 \\
\hline Fish oil & $\%$ & 9.2 & 1.1 & 1.5 \\
\hline
\end{tabular}

As reference [53].

Table 2. Sources of oleic, linoleic, and linolenic fatty acids in animal feeds.

\section{Conclusion}

Higher CLA values in the muscle tissue of intensively finished lambs are not easily explained. To increase the CLA yield in lamb meat it is essential to provide lamb an appropriate substrate for the formation of CLA. The provision of source of dietary linoleic acid appears to increase the CLA concentration to the greatest extent. Dietary forage such as grass or legume hay appears to facilitate the establishment of the micro-flora that enhances the formation and deposition 
of CLA in the tissues; also, the provision of modest amounts of grain is more conducive to CLA synthesis rather than high levels of grain. Regarding the recommended daily intake for appreciation of health benefits in humans $(3500 \mathrm{mg} / \mathrm{d})$, this amount of CLA supplied to meat lamb will partially provide the CLA requirement for everyone under conditions of this study.

\section{Acknowledgements}

The authors would like to thank the Chairman and staffs of the Institute of Khalat Phoshan Educational and Agricultural Research Station located in University of Tabriz in Iran for the financial support and their technical assistance in the preparation and provision of research information for this chapter; we also thank the University of Mohaghegh Ardabili for providing scholarships. We are grateful to the honorable officials of the Laboratory of the Faculty of Chemistry of the University of Tabriz, the Fellow of the Standard Ardabil Day Institute, the Evonik Manufacturing Company Group and Tehran Pars Biopharmacy Co., who have been collaborating in various analyses of the samples and data.

\section{Author details}

Akbar Taghizadeh $^{1 *}$ and Jamal Seifdavati ${ }^{2}$

*Address all correspondence to: ataghius@yahoo.com

1 Department of Animal Science, Faculty of Agriculture, University of Tabriz, Iran

2 Department of Animal Science, Faculty of Agriculture, University of Mohaghegh Ardabili, Iran

\section{References}

[1] Haddad G. Bitter vetch grains as a substitute for soybean meal for growing lambs. Livestock Science. 2006;99:221-225. DOI: 10.1016/j.livprodsci.2005.06.014

[2] White CL, Habury CD, Young P, Phililips N, Wiese SC, Milton JB, Davidson RHM, Siddiqe KH, Harris D. The nutritional value of Lathyrus cicer and Lupin agustifolius grain for sheep. Animal Feed Science and Technology. 2002;99:45-64. DOI: 10.1016/ S0377-8401(02)00035-4

[3] Lanza M, Bella M, Barbagallo D, Fasone V, Finocchiaro L, Priolo A. Effect of partially or totally replacing soybean meal and maize by chickpeas (Cicer arietinum L.) in lamb diets: Growth performances, carcass and meat quality. Animal Research. 2003;52:263270. DOI: 10.1016/S0377-8401(03)00166-4

[4] Scerra M, Caparra P, Foti F, Cilione C, Zappia G, Motta C, Scerra V. Intramuscular fatty acid composition of lambs fed diets containing alternative protein sources. Meat Science. 2011;87:229-233. DOI: 10.1016/j. meatsci.2010.10.015 
[5] Scollan N, Hocquette JF, Nuernberg K, Dannenberger D, Richardson I, Moloney A. Innovations in beef production systems that enhance the nutritional and health value of beef lipids and their relationship with meat quality. Meat Science. 2006;74:17-33. DOI: 10.1016/j.meatsci.2006.05.002

[6] Mir Z, Rushfeldt ML, Mir PS, Paterson LJ, Weselake RJ. Effect of dietary supplementation with either conjugated linoleic acid (CLA) or linoleic acid rich oil on the CLA content of lamb issues. Small Ruminant Research. 2000;36:25-31. DOI: 10.1016/ S0921-4488(99)00087-5

[7] Nürnberg K, Nürnberg G, Ender K, Lorenz S, Winkler K, Rickert R, Steinhart H. $\mathrm{N}-3$ fatty acids and conjugated linoleic acids of longissimus muscle in beef cattle. European Journal of Lipid Science and Technology. 2002;104:463-471. DOI: 10.1002/1438-9312(200208)104:83.0.CO;2-U

[8] Wood JD, Enser M, Fisher AV, Nute GR, Sheard PR, Richardson RI. Fat deposition, fatty acid composition and meat quality: A review. Meat Science. 2008;78:343-358. DOI: 10.1016/j.meatsci.2007.07.019

[9] Dhiman TR, Satter LD, Pariza MV, Galli MP, Albright K, Tolosa MX. Conjugated linoleic acid (CLA) content of milk from cows offered diets rich in linoleic and linolenic acid. Journal of Dairy Science. 2000;83:1016-1027. DOI: 10.3168/jds.S0022-0302(00)74966-6

[10] Moloney AP, Mooney MT, Kerry JP, Troy DJ. Producing tender and flavor some beef with enhanced nutritional characteristics. The Proceedings of the Nutrition Society. 2001;60:221-229. DOI: 10.1079/PNS200077

[11] GriinariJM, Bauman DE. Biosynthesis of conjugated linoleic acid and its incorporation into meat and milk in ruminants. In: Yurawecz MP, Mossoba MM, Kramer JKG, Pariza MW, Nelson GJ, editors. Advances in Conjugated Linoleic Acid Research, Vol. I. AOCS Press, Champaign, IL, 1999; pp: 180-200. DOI: 10.5713/ajas.2003.306

[12] Abdullah Y, Muwalla MM, Qudsieh RI, Titi HH. Effect of bitter vetch (Vicia ervilia) seeds as a replacement protein source of soybean meal on performance and carcass characteristics of finishing Awassi lambs. Tropical Animal Health and Production. 2010;42:293300. DOI: $10.1007 / \mathrm{s} 11250-009-9420-\mathrm{x}$

[13] Gül M, Yörük MA, Macit M, Esenbuga N, Karaoğlu M, Aksakal V, Aksu MI. The effects of diets containing different levels of common vetch seed (Vicia sativa) on fattening performance, carcass and meat quality characteristics of Awassi male lambs. Journal of the Science of Food and Agriculture. 2004;85:1439-1443. DOI: 10.1002/jsfa.2120

[14] Seifdavati J, Taghizadeh A. Fatty acid composition of meat from lambs fed diets. Global Advanced Research Journal of Food Science and Technology. 2012;1(2):018-034. http:// garj.org/garjfst/index.htm

[15] Gargallo S, Calsamiglia S, Ferret A. Technical note: A modified three-step in vitro procedure to determine intestinal digestion of proteins. Journal of Animal Science. 2006;84:2163-2167. DOI: 10.2527/jas.2004-704 
[16] McNiven MA, Prestløkken E, Mydland LT, Mitchell AW. Laboratory procedure to determine protein digestibility of heat-treated feedstuffs for dairy cattle. Animal Feed Science and Technology. 2002;96:1-13. DOI: 10.1016/S0377-8401(01)00340-6

[17] Seifdavati J, Taghizadeh A, Janmohammadi H, Rafat A, Alijani S. Determination nutritive value of some Iranian legume grains for ruminants using nylon-bag and in vitro techniques and their effects on performance of fattening lambs [thesis]. Tabriz, Iran: Faculty of Agriculture, Tabriz University; 2013 (In Persian)

[18] Seifdavati J, Taghizadeh A, Janmohammadi H, Rafat A, Alijani S. In situ ruminal degradability and in vitro intestinal digestibility of crude protein from some minor legume species. African Journal of Biotechnology. 2013;12:2293-2302. DOI: 10.5897/AJB12.944

[19] Harfoot CG, Hazlewood GP. Lipid metabolism in the rumen. In: Hobson PN, editor. The Rumen Microbical Ecosystem. London: Elsevier Applied Science Pubblishers; 1988. pp. 285-322. DOI: 10.1016/0079-6832(78)90004-6

[20] McNiven MA, Duynisveld J, Charmley E Mitchell A. Processing of soybean affects meat fatty acid composition and lipid peroxidation in beef cattle. Animal Feed Science and Technology. 2004;116:175-184. DOI: 10.1016/j.anifeedsci.2004.07.005

[21] Sinclair LA. Nutritional manipulation of the fatty acid composition of sheep meat:A review. Journal of Agricultural Science. 2007;145:419-434. DOI: 10.1017/S0021859607007186

[22] Keys A, Anderson JT, Grande F. Serum cholesterol response to changes in the diet. IV. Particular saturated fatty acids in the diet. Metabolism. 1965;14(7):747-758. DOI: 10.1016/0026-0495(65)90001-6

[23] Hunter JE, Zhang J, Kris-Etherton PM. Cardiovascular disease risk of dietary stearic acid compared with trans, other saturated, and unsaturated fatty acids: A systematic review. The American Journal of Clinical Nutrition. 2010;91(1):46-63. DOI: 10.3945/ ajcn.2009.27661

[24] Priolo A, Lanza A, Galofaro V, Fasone V, Bella A. Partially or totally replacing soybean meal and maize by chickpeas in lamb diets: Intramuscular fatty acid composition. Animal Feed Science and Technology. 2003;108:215-221. DOI: 10.1016/S0377-8401(03)00166-4

[25] Rizzi L, Simioli M, Sardi L, Monetti PM. Carcass quality, meat chemical and fatty acid composition of lambs fed diets containing extruded soybeans and sunflower seeds. Animal Feed Science and Technology. 2002;97:103-114. DOI: 10.1016/S0377-8401(01)00344-3

[26] Zhou L, Nilsson A. Sources of eicosanoid precursor fatty acid pools in tissues. Journal of Lipid Research. 2001;42(10):1521-1542. PMID: 11590208

[27] McAfee AJ, McSorley EM, Cuskelly GJ, Moss BW, Wallace JMW, Bonham MP, Pearson AM. Red meat consumption: An overview of the risks and benefits. Meat Science. 2010;84:1-13. DOI: 10.1016/j.meatsci.2009.08.029

[28] KromhoutD.Fish(oil)consumption and coronaryheartdisease.In:GalliC,SimopoulosAP, editors. Dietary n-3 and n-6 fatty acids. Biological Effects and Nutritional Essentiality. New York, USA:Plenum Publishing;1989.pp.273-282.DOI:10.1007/978-1-4757-2043-3_25 
[29] Bonanome A, Grundy SM. Effect of dietary stearic acid on plasma cholesterol and lipoprotein levels. New England Journal of Medicine. 1998;388:1244-1248. DOI: 10.1056/ NEJM198805123181905

[30] Priolo A, Waghorn G, Lanza M, Biondi L, Pennisi P. Polyethylene glycol as a means for reducing the impact of condensed tannins in carob pulp: Effects on lamb growth, performance and meat quality. Journal of Animal Science. 2000;78:810-816. DOI: $10.2527 / 2000.784810 x$

[31] French P, Stanton C, Lawless F, O'Riordan E, Monahan F, Caffrey P. Fatty acid composition, including conjugated linoleic acid, of intramuscular fat from steers offered grazed grass, grass silage, or concentrate-based diets. Journal of Animal Science. 2000;78:28492855. DOI: $10.2527 / 2000.78112849 x$

[32] De La Torre A, Gruffat D, Durand D, Micol D, Peyron A, Scislowski V, Bauchart D. Factors influencing proportion and composition of CLA in beef. Meat Science. 2006;73:258-268. DOI: 10.1016/j.meatsci.2005.11.025

[33] Banni S, Heys CSD, Wahle KWJ. Conjugated linoleic acid as anticancer nutrients: Studies in vivo and cellular mechanisms. In: Sebedio J, Christie WW, Adolf R, editors. Advances in Conjugated Linoleic Acid Research, Vol (2). Urbana, IL, USA: AOCS Press; 2003. pp. 267-281

[34] Pariza MW. The biological activities of conjugated linoleic acid. Chapter 2. In: Yurawecz MP, Mossoba MM, JKG K, Pariza MW, Nelson GJ, editors. Advances in Conjugated Linoleic Acid Research, Vol. 1. Champaign, IL, Urbana, USA: AOCS Press; 1999. pp. 12-20

[35] Ha YL, Grimm NK, Pariza MW. Anticarcinogens from fried ground beef: Heat-altered derivatives of linoleic acid. Carcinogenesis. 1987;8(12):1881-1887. DOI: 10.1093/carcin/8. 12.1881

[36] Ip C, Chin SF, Scimeca JA, Pariza MW. Mammary cancer prevention by conjugated linoleic acid. Cancer Research. 1991;51:6118-6124. PMID: 1933874

[37] Belury MA. Conjugated dienoic linoleate: A polyunsaturated fatty acid with unique chemical properties. Nutrition Reviews. 1995;35:83-89. DOI: 10.1111/j.1753-4887.1995. tb01525.x

[38] Parodi PW. Cow's milk fat components as potential anticarcinogenic agents. The Journal of Nutrition. 1997;127:1055-1060. PMID: 9187617

[39] McGuire MA, McGuire MK. Conjugated linoleic acid (CLA): A ruminant fatty acid with beneficial effects on human health. Journal of Animal Science. 2000;77(Suppl):1-8. DOI: 10.2527/jas2000.00218812007700ES0033x

[40] Gallardo MA, Rubén P, Carmen G. Fatty acid composition of Longissimus dorsi muscle of Suffolk down lambs fed on different dryland forages. Chilean Journal of Agricultural Research. 2011;71(4):566-571. DOI: 10.4067/S0718-58392011000400011

[41] Byers FM, Schelling GT. Lipid in ruminant nutrition. In: Church DC, editor. Ruminant Animal: Digestive Physiology and Nutrition. IL: Waveland Pub. Prospect Heights; 1993. pp. 298-312 
[42] Chilliard Y, Ferlay A, Rouel J, Lamberet G. A review of nutritional and physiological factors affecting goat milk lipid synthesis and lipolysis. Journal of Dairy Science. 2003;86:1751-1770. DOI: 10.3168/jds.S0022-0302(03)73761-8

[43] Manner WN, Maxwell RJ, Williams JE. Effect of dietary regimen and tissue site on bovine fatty acid profiles. Journal of Animal Science. 1984;59:109-121. DOI: 10.2527/ jas1984.591109x

[44] Murphy SR, McNiven MA. Raw or roasted lupin supplementation of grass silage diets for beef steers. Animal Feed Science and Technology. 1994;46:23-35. DOI: 10.1016/0377-8401(94)90062-0

[45] Khanal RC, Olson KC. Factors affecting conjugated linoleic acid (CLA) content in milk, meat, and egg: A review. Pakistan Journal of Nutrition. 2004;3:82-98. DOI: 10.3923/ pjn.2004.82.98

[46] Tilak R, Dhiman SHN, Amy LU. Factors affecting conjugated linoleic acid content in milk and meat. Critical Reviews in Food Science. 2005;45:463-482. DOI: 10.1080/10408390591034463

[47] Valvo MA, Lanza M, Bella M, Fasone V, Scerra M, Biondi L. Effect of ewe feeding system (grass vs. concentrate) on intramuscular fatty acids of lambs raised exclusively on maternal milk. Animal Science. 2005;81:431-436. DOI: 10.1079/ASC50480431

[48] Mohammed R, Kennelly JJ, Kramer JK, Beauchemin KA, Stanton CS, Murphy JJ. Effect of grain type and processing method on rumen fermentation and milk rumenic acid production. Animal. 2010;4:1425-1444. DOI: 10.1017/S175173111000039X

[49] Vasta V, Makkar HPS, Mele M, Priolo A. Ruminal biohydrogenation as affected by tannins in vitro. British Journal of Nutrition. 2009;102:82-92. DOI: 10.1017/S0007114508137898

[50] Vasta V, Mele M, Serra A, Scerra M, Luciano G, Lanza M, Priolo A. Metabolic fate of fatty acid involved in ruminal biohydrogenation in sheep fed concentrate or herbage with or without tannins. Journal of Animal Science. 2009;87:2674-2684. DOI: 10.2527/ jas.2008-1761

[51] Vasta V, Pennisi P, Lanza M, Barbagallo D, Bella M, Priolo A. Intramuscular fatty acid composition of lambs given a tanniniferous diet with or without polyethylene glycol supplementation. Meat Science. 2007;76:739-745. DOI: 10.1016/j.meatsci.2007.02.015

[52] FAO (Food and Agriculture Organization of the United Nations). Follow-up to the Guidelines for International Cooperation in the Livestock and Meat Sector. Intergovernmental Group on Meat and Dairy Products. Nineteenth Session. Rome; 2007. pp. 27-29. http://www.fao.org

[53] Rodrigues TI, Chen Y, Ferreira I, Olalquiaga JR, Hopkins D. Manipulation of omega-3 PUFAs in lamb: Phenotypic and genotypic views. Food Science and Food Safety. 2015;14:189-204. DOI: 10.1111/1541-4337.12131

[54] Shingfield KJ, Bonnet M, Scollan ND. Recent developments in altering the fatty acid composition of ruminant-derived foods. Animal. 2013;7:132-162. DOI: $10.1017 / S 1751731112$ 001681 
[55] Demirel G, Wachira AM, Sinclair LA, Wilkinson RG, Wood JD, Enser M. Effects of dietary n-3 polyunsaturated fatty acids, breed and dietary vitamin $E$ on the fatty acids of lamb muscle, liver and adipose tissue. The British Journal of Nutrition. 2004;91:551-565. DOI: 10.1079/BJN20031079

[56] Wachira AM, Sinclair LA, Wilkinson RG, Enser M, Wood JD, Fisher AV. Effects of dietary fat source and breed on the carcass composition, n-3 polyunsaturated fatty acid and conjugated linoleic acid content of sheep meat and adipose tissue. The British Journal of Nutrition. 2002;88:697-709. DOI: 10.1079/BJN2002727

[57] Ponnampalam EN, Butler KL, Pearce KM, Suzanne IM, Pethick DW, Ball AJ, Hopkins DL. Sources of variation of health-claimable long-chain omega-3 fatty acids in meat from Australian lamb slaughtered at similar weights. Meat Science. 2014;96:1095-1103. DOI: 10.1016/j.meatsci.2012.11.039

[58] Ferreira EM, Pires AV, Susin I, Gentil RS, Parente MOM, Nolli CP, Meneghini RCM, Mendes CQ, Ribeiro CVDM. Growth, feed intake, carcass characteristics, and meat fattyacid profile of lambs fed soybean oil partially replacedby fish oil blend. Animal Feed Science and Technology. 2014;187:9-18. DOI: 10.1016/j.anifeedsci.2013.09.016

[59] Wynn RJ, Daniel ZCTR, Flux CL, Craigon J, Salter AM, Buttery PJ. Effect of feeding rumen-protected conjugated linoleic acid on carcass characteristics and fatty acid composition of sheep tissues. Journal of Animal Science. 2006;84:3440-3450. DOI: 10.2527/ jas.2006-159

[60] Castro T, Manso T, Mantecón AR, Guirao J, Jimeno V. Fatty acid composition and carcass characteristics of growing lambs fed diets containing palm oil supplements. Meat Science. 2005;69:757-764. DOI: 10.1016/j.meatsci.2004.11.008

[61] Seabrook JL, Peel RK, Engle TE. The effects of replacing dietary carbohydrate with calcium salts of fatty acids on finishing lamb feedlot performance, blood metabolites, muscle fatty acid composition, and carcass characteristics. Small Ruminant Research. 2011;95:97-103. DOI: 10.1016/j.smallrumres.2010.10.009

[62] Gómez-Cortés P, Gallardo B, Mantecón AR, Juárez M, La Fuente MA, Manso T. Effects of different sources of fat (calcium soap of palm oil vs. extruded linseed) in lactating ewes' diet on the fatty acid profile of their suckling lambs. Meat Sci. 2014;96:1304-1312. DOI: 10.1016/j.meatsci.2013.10.040

[63] Andrés S, Morán L, Aldai N, Tejido ML, Prieto N, Bodas R, Giráldez FJ. Effects of linseed and quercetin added to the diet of fattening lambs on the fatty acid profile and lipid antioxidant status of meat samples. Meat Science. 2014;97:156-163. DOI: 10.1016/j. meatsci.2014.02.001 



\section{Section 4}

Nutritional Composition of Meat 



\title{
Nutritional Composition of Meat
}

\author{
Rabia Shabir Ahmad, Ali Imran and \\ Muhammad Bilal Hussain \\ Additional information is available at the end of the chapter
}

http://dx.doi.org/10.5772/intechopen.77045

\begin{abstract}
Meat ranks among one of the most significant, nutritious and favored food item available to masses, which aids in fulfilling most of their body requirements. It has played a vital role in human evolution and is an imperative constituent of a well-balanced diet. It is a good source of proteins, zinc, iron, selenium, and phosphorus followed by vitamin A and B-complex vitamins. Average value of meat protein is about $23 \%$ that varies from higher to lower value according to the type of meat source. Meat fat and its fatty acid profile is point to worry, with respect to its consumption, but its moderate usage is always advised by doctors and nutritionists, in order to lead a healthy life. Fat content of animal carcasses ranges between 8 and $20 \%$. Quality traits of meat along with its nutritional composition become dependent upon animal breed type, feeding source (grains, pasture and grass), genetics of animal and post mortem techniques. This chapter will mainly focus on the variant aspects of nutritional constituents of meat including proteins and essential amino acids, fats and fatty acid profile, carbohydrates, vitamins and minerals along with their health benefits to human health.
\end{abstract}

Keywords: meat, nutritional value, proteins, saturated fats, minerals, vitamins

\section{Introduction}

Ingestion of fresh, healthy and wholesome food materials play a crucial role in maintaining the health status of human beings. The term balanced diet has gained immense popularity globally owing to the increasing awareness regarding the maintenance of health status among the masses. Balanced diet ensures the intake of all the essential nutrients, which are required by the human body to perform the daily life functions [1]. In this scenario, awareness of nutritional composition of the food stuffs has become quite significant in having a balanced meal, 
which in-turn ensures the health status of individuals. Nutritional composition refers to the comprehensive frame of information regarding vital nutritional components of food items and offers energy values. The nutrients are the elements that provide nourishment essential for the maintenance of life and for growth, which includes both the macro- and micronutrient. Macro-nutrients are those that are required by the human body in large amounts and these include proteins, fats and carbohydrates. Micro-nutrients are those elements which are required by the body in small amount and comprising of vitamins, minerals and fiber [2]. All of these are being supplied by number of food stuffs including meat, cereal grains, milk, fruits and vegetables. Among them meat holds a key spot which fulfills most of the protein requirements of the humans. Different types of meats are present including the beef, mutton, lamb, chicken and fish etc. Each and every type of meat is significant in its own value with little differences in its composition [3]. The detailed information regarding its nutritional composition is as follows;

\section{Nutritional composition of meat}

Meat ranks among one of the most significant, nutritious and energy-rich natural food product, utilized by the humans to fulfill their regular body requirements. It is considered quite important in maintaining a healthy and balanced diet, which is essential in accomplishing optimum human growth and development. Although, few epidemiological studies have also pointed a possible relationship between its consumption and the elevated risks of having cardiovascular diseases, various forms of cancers and metabolic disorders but still its role in the human species evolution, specifically in its brain and intellectual development cannot be ignored [4].

In accordance with European legislation, meat is defined as the edible portions, obtained from domestic animals including caprine, bovine, ovine and porcine, including the poultry meat, farmed and wild animals. It is a rich source of high value proteins, variety of fats including omega-3 polyunsaturated fatty acids, zinc, iron, selenium, potassium, magnesium, sodium, vitamin A, B-complex vitamins and folic acid. Its composition varies with reference to its breed, type of feed being ingested, climatic conditions and also on the meat cut, which imparts a considerable difference on its nutritional and sensorial properties [4].

From the nutritional point of view, meat is considered as a rich essential amino acids source whereas, mineral contents to a lesser extent. Apart from it, essential fatty acids and vitamins also make a part of it. Organ meat like liver is quite an enriched source of Vitamin A, Vitamin $\mathrm{B}_{1}$ and nicotinic acid. The research is still in progress for the better understanding of the probable differences among the nutritional value of different meat cuts, variant animal species and breeds. It is quite evident from the previous research that the meat having lesser connective tissues is likely to have low scores of digestion and absorption [5]. Moreover, the meat having more connective tissues are supposed to have less contents of essential amino acids, which make them less nutritious as compared to the meat piece having lesser connective tissues and results in more digestibility and nutritional value [3]. Following Table 1 shows the nutritional composition of different sort of meat products. 


\begin{tabular}{|c|c|c|c|c|c|c|c|c|c|}
\hline Meat cut & $\begin{array}{l}\text { Protein } \\
\text { (g) }\end{array}$ & $\begin{array}{l}\text { Sat. fat } \\
\text { (g) }\end{array}$ & Fat (g) & $\begin{array}{l}\text { Energy } \\
\text { (kcal) }\end{array}$ & $\begin{array}{l}\text { Vit. B } \\
\text { (mcg) }\end{array}$ & $\begin{array}{l}\mathrm{Na} \\
(\mathrm{mg})\end{array}$ & $\begin{array}{l}\mathrm{Zn} \\
(\mathrm{mg})\end{array}$ & $\begin{array}{l}P \\
(\mathrm{mg})\end{array}$ & $\mathrm{Fe}(\mathrm{mg})$ \\
\hline Chicken breast, raw & 24.2 & 0.2 & 8.5 & 178 & 0.39 & 71 & 0.9 & 199 & 1.2 \\
\hline Beef, steak cuts, raw & 21 & 1.9 & 4.5 & 123 & 1.9 & 59 & 1.7 & 167 & 1.3 \\
\hline Chicken, raw & 22.8 & 0.6 & 1.9 & 113 & 0.70 & 78 & 1.4 & 202 & 0.7 \\
\hline Beef, calf, loin, raw & 20 & 3.4 & 7.3 & 146 & 1.1 & 22 & 3 & 193 & 0.10 \\
\hline Beef, loin, raw & 20.9 & 1.5 & 3.2 & 115 & 2 & 59 & 3.7 & 142 & 1.6 \\
\hline Pork, chop, raw & 18.1 & 10.8 & 31.7 & 353 & 1 & 60 & 1.8 & 190 & 1.4 \\
\hline Pork, loin, raw & 21.9 & 1.7 & 4.9 & 134 & 1.1 & 55 & 1.9 & 220 & 0.7 \\
\hline Pork, leg, raw & 20.8 & 2.8 & 7.8 & 155 & 1.2 & 84 & 2.6 & 164 & 0.8 \\
\hline Turkey, skinless, raw & 19.9 & 1.8 & 7.1 & 136 & 1.9 & 42 & 1.5 & 209 & 2.1 \\
\hline $\begin{array}{l}\text { Duck meat, skinless, } \\
\text { raw }\end{array}$ & 19.4 & 1.8 & 6.6 & 130 & 2.8 & 90 & 1.8 & 201 & 2.5 \\
\hline $\begin{array}{l}\text { Turkey, breast, } \\
\text { skinless, raw }\end{array}$ & 23.6 & 0.5 & 1.6 & 106 & 1 & 62 & 0.5 & 208 & 0.6 \\
\hline $\begin{array}{l}\text { Chicken breast, } \\
\text { skinless, raw }\end{array}$ & 23.8 & 0.4 & 1.28 & 109 & 0.40 & 59 & 0.7 & 218 & 0.4 \\
\hline $\begin{array}{l}\text { Mutton, chop or meat, } \\
\text { raw }\end{array}$ & 20 & 2.4 & 4.8 & 122 & 2 & 63 & 3.6 & 221 & 1.9 \\
\hline
\end{tabular}

Table 1. Nutritional composition of meat $[4,6]$.

\subsection{Water}

Water is one of the important constituents of all food materials. In general, there are three types of food products depending upon their moisture contents, firstly perishable commodities (having more than 70\% moisture content in them), non-perishable commodities (having around $50-60 \%$ moisture contents) and stable food materials (with less than $15 \%$ moisture). The more the water content of any food material the lesser are the chances of its longer shelf life as micro-organisms have greater chance to grow on them that in turn, limit their lives.

Meat ranks among the perishable food material, as it contain around more than $70 \%$ of moisture in it. Apart from reduction in shelf life, its presence imparts a strong impact on the color, texture and flavor of muscle tissues of meat. Adipose tissues (tissues on the abdominal part of the animal) contain less moisture content, which leads to the fact that if the animal is fatter it will be having lower water content in its carcass and vice versa. Younger and leaner animals exhibited around $72 \%$ of moisture content [7].

Major portion of water contents in meat tissues exist in free- state within muscle fibers and smaller amount of it is present in the connective tissues. During the processing conditions, such as curing and heat treatment followed by the storage, small percentage of the water remains within the muscle fiber which is termed as the "bound water". The three dimensional 
structure of muscle fiber fortified with the pressure and temperature helps the water to retain in the muscles during the processing conditions, while most of the water "lost" during these circumstances known as "free water". The water holding ability of meat could be altered by the disruptions of its muscle fibers, which resultantly aid in the enhancement of the shelf life of meat products. There are numerous methods involved in this regard containing chopping, grinding, salting, freezing, thawing, breakdown of connective tissues by enzymatic or chemical means, heating application and use of chemicals or organic additives altering the acidity $(\mathrm{pH})$ of meat are the processes that can affect the final water contents of meaty products [8].

\subsection{Carbohydrates}

The main source of the carbohydrate in the animal body is its liver, which contains about $1 / 2$ of the total carbohydrates present in the body. They are stored in the form of "glycogen" mainly in the liver and muscles but also in glands and organs to lesser extent. Its substantial quantities are present in blood in the form of glucose. The glycogen has an indirect impact on the meat color, texture, tenderness and water holding capacity of it. The conversion of stored glycogen to glucose; and from glucose to lactic acid is quite a complex process and all these modifications are governed by the action of hormones and enzymes [9].

During the early stage of aging, the lactic acid content of muscles increases, thus lowering the $\mathrm{pH}$. The $\mathrm{pH}$ has a very strong influence on the muscle texture, tenderness, color and also on water-holding capacity. The normal $\mathrm{pH}$ of the muscle considers being around 5.6. If an animal suffers from severe stress or exercise just before the slaughter and have no chance to regain its normal glycogen levels, then a minute amount of glycogen will be there to convert into lactic acid causing an elevated $\mathrm{pH}$ (i.e. 6.5) and as a result, meat muscles get dark, firm and dry (DFD). This type of meat results from exhaustion and then causes depletion of glycogen before slaughter. This occurs not so often in beef ( $2 \%)$, but also affected the other ones that are called as "Dark Cutters". The main reason for the dark colored meat with high $\mathrm{pH}$ is owing to the higher water holding capacity. This causes the muscles to absorb more water, which makes them to absorb the incident light rather than to reflect it from the meat surface, thus causing the darker appearance of the meat. This DFD defect is quite disliked by the retailers and customers, affecting heavily on its sensorial and nutritional properties, so stress and rough handling of animals should be avoided just prior to slaughtering [10].

A quite speedy postmortem causes a drop in the muscle $\mathrm{pH}$ (i.e. 5.0) is recognized by pale, soft and exudative condition (PSE), which is quite common in pork meat. PSE affected muscle portion is recognized by low water-holding capacity, soft texture and pale yellow color. The softer muscle structure of PSE meat causes its lower water-holding capacity, which is then accountable for more reflectance of incident light, thus making the color of meat as pale yellow [11].

All the above mentioned conditions of DFD and PSE relates to the carbohydrate contents of the meat, which has considerable effect on nutritional value of meat.

\subsection{Proteins and its amino acids}

Meat ranks among one of the protein-rich foods, providing high biological value to the masses. Proteins are naturally occurring complex nitrogenous compounds having very high molecular 
weight consisting of carbon, hydrogen, oxygen and most importantly nitrogen. Few of the proteins also have phosphorous and sulfur in their structures. All these components chemically linked together to form different types of individual proteins, exhibiting different properties. These vary from one tissue to the other within a same living organism and also in corresponding tissues of different species. The proteins are more complex than the carbohydrates and fats from their size and constituents. The percentage of meat protein component varies extensively in different types of meats [12]. In general, the average value of the meat protein is about $22 \%$, but it could range from high protein value of $34.5 \%$ in chicken breast to as low as $12.3 \%$ protein in duck meat. The protein digestibility-corrected amino acid scores (PDCAAS) which depict the protein digestibility reveals that meat has high score of 0.92 as compared to other protein sources including lentils, pinto beans, peas and chickpeas scoring 0.57-0.71 [13]. Protein quality is mainly concerned with the availability of amino acids present in it.

Amino acids serve as the building blocks of the proteins. The nutritional value of meat can be varied to great deal by the presence or absence of numerous amino acids. One hundred and ninety two are known among which only 20 are used to prepare the proteins. From these 20 amino acids, 08 are considered as the essential amino acids, as these could not be prepared by the human body, so must be taken by the diet. Other 12 are the non-essential amino acids that could be manufactured by the human body but only if their particular dietary sources are being ingested, otherwise, it could result in the protein malnutrition. The Table 2 shows all non-essential and essential amino acids present in meat.

The beef meat appears to have higher contents of valine, lysine and leucine as compared to lamb and pork. Studies have revealed that main reason of the difference in essential amino acid proportion lies with the breed, animal age and muscle location. Previous research studies reported that contents of valine, isoleucine, phenylalanine, arginine and methionine in the animal meat increase with its age [16]. The essential amino acid contents also differ with the different parts of the carcass. Their composition could also be affected by the application of processing techniques including heat and ionization radiations, but only when the severe prolonged mode of these conditions are being applied [17]. In some cases, these amino acids are not being available for the human use. In a study, some researchers found out that only $50 \%$ of lysine was available at $160^{\circ} \mathrm{C}$, while $90 \%$ of it was there at $70^{\circ} \mathrm{C}$. Sometimes the interaction of the other constituents with the proteins has put an effect on the availability of essential amino acids. Smoking and salting of the meat has also played its role in this regard. Apart from the effect of the processing conditions, the storage has also imparted its effect on amino acids, in case of canned meat [18].

\subsection{Fat and fatty acids}

Fats rank among one of the three major macro-nutrients, including carbohydrates and proteins. Fat contents are known as triglycerides that are esters of three fatty acid chains and the alcohol glycerol. Meat contains fatty tissues (fat cells filled with lipids) that have varying amount of fat. In meat, fat content functions as energy deposits, protective padding in the skin and around organs especially heart and kidney as well as provides insulation against body temperature losses [19]. Fat content in animal carcass varies from 8 to $20 \%$ (latter is only in pork). The fatty acid and fat composition of fatty tissue differs significantly in different locations among poultry 


\begin{tabular}{|c|c|c|c|c|}
\hline \multicolumn{5}{|c|}{ Essential amino acids } \\
\hline Amino acids & Category & Beef & Lamb & Pork \\
\hline Lysine & Essential & 8.2 & 7.5 & 7.9 \\
\hline Leucine & Essential & 8.5 & 7.2 & 7.6 \\
\hline Isoleucine & Essential & 5.0 & 4.7 & 4.8 \\
\hline Cystine & Essential & 1.5 & 1.5 & 1.2 \\
\hline Threonine & Essential & 4.2 & 4.8 & 5.2 \\
\hline Methionine & Essential & 2.2 & 2.4 & 2.6 \\
\hline Tryptophan & Essential & 1.3 & 1.2 & 1.5 \\
\hline Phenylalanine & Essential & 4.1 & 3.8 & 4.3 \\
\hline Arginine & Essential & 6.4 & 6.8 & 6.6 \\
\hline Histidine & Essential & 2.8 & 2.9 & 3.1 \\
\hline Valine & Essential & 5.6 & 5.1 & 5.2 \\
\hline \multicolumn{5}{|c|}{ Non-essential amino acids } \\
\hline Amino acid & Category & Beef & Lamb & Pork \\
\hline Proline & Non-essential & 5.2 & 4.7 & 4.4 \\
\hline Glutamic acid & Non-essential & 14.3 & 14.5 & 14.6 \\
\hline Aspartic acid & Non-essential & 8.9 & 8.6 & 8.8 \\
\hline Glycine & Non-essential & 7.2 & 6.8 & 6.0 \\
\hline Tyrosine & Non-essential & 3.3 & 3.3 & 3.1 \\
\hline Serine & Non-essential & 3.9 & 3.8 & 4.1 \\
\hline Alanine & Non-essential & 6.3 & 6.2 & 6.4 \\
\hline
\end{tabular}

Table 2. Amino acid composition in fresh meat $[6,14,15]$.

and other meat products such as offal, sausages and ham etc. External body fat is softer than the internal fat that surrounds the organs owing to the higher content of unsaturated fat in external animal parts. Skin is the main fat source in poultry meat. In the main retail cuts, fat content in chicken and turkey ranges between 1 and $15 \%$ and meat cuts with skin have higher percentage. Cooking can have a significant effect on fatty acid composition and meat fat content. Scientific evidence reported the considerable losses of fat in numerous meat cuts which were referred to broiling, grilling and pan-frying without added fat [20].

Among the fatty acid composition, meat contains unsaturated fatty acids; oleic (C-18:1), linoleic (C-18:2), linolenic (C-18:3) and arachidonic (C-20:4) acid appear to be essential. They are necessary constituents of mitochondria, cell wall and other active metabolic sites. Linoleic acid (C-18:2) is abundantly present in vegetable oils such as soya and corn oils with its concentration 20 times in meat and linolenic acid (C-18:3) occurs abundantly in leafy parts of plants. Eicosapentaenoic acid (C-20:5) and docosahexaenoic acid (C-22:6) are normally 
present at low concentration in meat tissues, but these are present in high concentrations in fish and fish oils [21]. Polyunsaturated fatty acids concentrations as well as cholesterol in muscular and offal tissues of common meat species are shown in Table 3.

It is obvious that the linoleic acid concentration is more in lean meat of pig than in ox or sheep meat. These variations in concentration of fatty acids composition among different species are also revealed in kidney and liver fatty acid profile. The liver tissue in all the mentioned animal species is suggested as a rich source of polyunsaturated fatty acids. On the other hand, brain has distinctively high concentration of C-22 polyunsaturated fatty acids. It is tabulated that the concentration of cholesterol in offal tissues, particularly brain is more than the concentration in muscle tissues [26].

From the number of polyunsaturated fatty acids, omega 3 fatty acids justify their special attention as they play a protective role in general human health particularly cardiovascular diseases. Seafood is the main source of omega 3 fatty acids. Though, meat can contribute up to $20 \%$ of long chain omega 3 polyunsaturated fatty acids intake. This polyunsaturated omega 3 content in meat depends on the feeding source and it is higher in forage-based and grass diet. It is also suggested that polyunsaturated fatty acids of animal fat are indispensable for the development of brain, particularly in the fetus. When linoleic and linolenic acids are ingested, they can be digested by animal liver and produce polyunsaturated fatty acids. Furthermore, the chain elongation of linoleic acid gives rise to the prostaglandins which are very important for the regulation of blood pressure. Prostaglandins are mostly found in organs and tissues and synthesized in the cell from essential fatty acids. They are produced by all nucleated cells and known as autocrine and paracrine lipid mediators that act on endothelium, uterine and platelet cells [27].

To avoid the possible harmful effects on health from the consumption of the meat of ruminant animals, there must be introduced a greater potential of unsaturation into their fats and fatty tissues. Generally, feeding of vegetable fats to sheep and cattle would be nullified because of the reduction or condensation by rumen bacteria. But, when they are firstly treated with

\begin{tabular}{|c|c|c|c|c|c|c|c|}
\hline Meat source & Cholesterol (mg/100 g) & C-18:2 & C-18:3 & C-20:3 & C-20:4 & C-22:5 & C-22:6 \\
\hline Mutton & 81 & 2.4 & 2.4 & Nil & Nil & Trace & Nil \\
\hline Beef & 62 & 2.1 & 1.4 & Trace & 1.1 & Trace & Nil \\
\hline Pork & 71 & 7.5 & 1.0 & Nil & Trace & Trace & 1.1 \\
\hline Brain & 2200 & 0.5 & Nil & 1.6 & 4.1 & 3.5 & 0.4 \\
\hline Pig's Kidney & 415 & 11.6 & 0.4 & 0.5 & 6.72 & Trace & Nil \\
\hline Sheep's Kidney & 399 & 8.2 & 4.1 & 0.6 & 7.2 & Trace & Nil \\
\hline Ox's kidney & 401 & 4.9 & 0.6 & Trace & 2.7 & Nil & Nil \\
\hline Sheep's Liver & 429 & 5.1 & 3.9 & 0.7 & 5.2 & 3.1 & 2.3 \\
\hline Pig's Liver & 262 & 14.8 & 0.4 & 1.2 & 14.4 & 2.4 & 3.9 \\
\hline Ox's Liver & 271 & 7.5 & 2.4 & 4.5 & 6.5 & 5.4 & 1.3 \\
\hline
\end{tabular}

Table 3. Polyunsaturated fatty acids and cholesterol in lean meat and offal [22-25] (as \% total fatty acids). 
formaldehyde, there would be the resistance in reduction and then results in increased potential of unsaturation in fat stores of ruminants. Because of the important role of meat in human diet, increasing its consumption rate through the years and considerable role in human health, numerous research studies were concentrated on different ways of fatty acid composition improvement in meat. Meat fatty acid composition can be changed through animal diet (feeding), certainly in single-stomach poultry and pigs where the alpha-linolenic, linoleic and longchain polyunsaturated fatty acid contents respond suddenly to elevated dietary applications. Significant difference was found between grain and pasture-fed animal's fatty acid composition that gives higher polyunsaturated fatty acid concentration in pasture-fed animal groups [28].

Digestive characteristics of animals may affect composition of meat fatty acids. Microbial enzymes encourage the hydrolysis of unsaturated fatty acids that leads to an increased stearic acid concentration that reaches in small intestine and gets absorbed there. Trans-fatty acids are formed in beef as a result of the bio hydrogenation by rumen bacteria. The most common and well known in meat from ruminant animals is conjugated linoleic acid (CLA), which has been proved to prevent cardiovascular diseases, obesity and diabetes [29].

\subsection{Minerals}

Minerals are the nutrients present in food materials that do not contain the element carbon in them and required for the proper growth, development as well as maintenance of human body. They are divided into two categories i.e. macro- and micro-minerals, on the basis of their requirement by the human body. Macro-minerals are those ones, which are required by the body in larger amount. These include sodium, calcium, phosphorus, magnesium, chloride potassium and sulfur, while micro-minerals refers to those who are required in smaller amounts including iron, zinc, iodine, copper, cobalt, manganese, selenium and fluoride [30]. The following Table 4 represents the micro- and macro-minerals of meat and meat products.

It is quite evident that potassium is quantitatively quite dominant mineral as compared to others i.e. followed by phosphorus, sodium and magnesium. Meat is also a very good source

\begin{tabular}{llllllllll}
\hline Meat source & $\mathbf{K}$ & $\mathbf{C u}$ & $\mathbf{F e}$ & $\mathbf{P}$ & $\mathbf{Z n}$ & $\mathbf{M g}$ & $\mathbf{N a}$ & $\mathbf{C a}$ \\
\hline Chopped Mutton, (raw) & 244 & 0.15 & 0.99 & 174 & 4.2 & 18.8 & 74 & 12.5 \\
Chopped Mutton, (grilled) & 303 & 0.25 & 2.5 & 205 & 4.2 & 22.7 & 101 & 17.9 & 5.5 \\
Beef, Steak (raw) & 335 & 0.1 & 2.4 & 275 & 4.2 & 24.4 & 68 & & \\
Beef, Steak (grilled) & 369 & 0.22 & 3.8 & 302 & 5.8 & 25.1 & 66 & 901 & 13.6 \\
Bacon (raw) & 267 & 0.2 & 1.0 & 95 & 2.4 & 12.2 & 976 & 11.6 \\
Bacon, (fried) & 516 & 0.2 & 2.7 & 228 & 3.7 & 25.8 & 2792 & 4.2 \\
Pork (raw) & 399 & 0.1 & 1.5 & 224 & 2.5 & 26.2 & 44 & & 8.2 \\
Chopped Pork, (grilled) & 259 & 0.1 & 2.5 & 179 & 3.6 & 14.8 & 60 & \\
\hline
\end{tabular}

Table 4. Mineral contents (mg/100 g) of meat and meat products [31, 32]. 
of iron, zinc and selenium. All these minerals perform variant functions for the growth, development and maintenance of human body that are described as follows.

\subsubsection{Potassium}

Potassium helps in metabolism, nerve impulses transmission, growth, muscle building and maintaining of acid-base balance in the human body.

\subsubsection{Phosphorus}

Phosphorus is an important mineral element that gives energy, forms phospholipids along with $\mathrm{Ca}$, which involves the formation of bones and teeth.

\subsubsection{Sodium}

Regulates water content of the body, aids in transport of $\mathrm{CO}_{2}$ and maintains osmotic pressure of body fluids.

\subsubsection{Magnesium}

Magnesium repairs and improves the growth of human body, maintains blood pressure, prevents tooth decay and helps to keep bones healthy.

\subsubsection{Zinc}

Zinc is the part of many enzymes, required for the body immune system, having role in cell division, growth and wound healing.

\subsubsection{Selenium}

Prevent cancer, poisonous effect of heavy metals and helps the body after vaccination.

\subsubsection{Iron}

Iron is one of the key mineral present in meat, which plays a vital role in human health and its deficiency causes several hindrances in the normal functioning of human body, particularly disturbs child growth and development [33]. The mode of metabolism of iron is quite different from the other mineral contents in the sense, that it is excreted and more than $90 \%$ of it is utilized internally in the body. Obligatory sources of iron and red blood cells disruption or losses are intestines, urinary tract, skin and also during menstrual bleeding among females. Its deficiency could be overcome primarily by the diet [34]. Iron is available in a number of food stuffs and occurs in two forms like heme and non-heme iron. The former one comes from the hemoglobin and myoglobin, so it is present in animal foods only and has a high degree of bioavailability that could easily be absorbed in the intestinal lumen [35]. 


\subsubsection{Organ meat as a mineral source}

It is quite evident that the offal organs are quite rich in the mineral contents like iron, zinc, and copper as compared to the minerals that are present in muscular tissues. The children on the fully vegetarian diet could lead them to retarded cognitive activity owing to zinc deficiency, so the ingestion of meat stuff has been emphasized [7]. Mineral contents of offal organs are depicted in Table 5.

\subsection{Vitamins}

Vitamins are a group of organic substances that function in a variety of dimensions in human body. These constituents although required in minute amounts and are very important for the proper growth, development and maintenance of the human body. They are especially required at the early age of life by the children. They partake in various metabolic processes involving series of chemical and biochemical reactions. One of their distinguishing features is that they generally cannot be prepared by the mammalian cells, so must be supplied through the diet [37]. They are generally classified into two groups on the basis of their solubility in water and fat i.e. water soluble vitamins and fat soluble vitamins. Water soluble vitamins include the B-complex vitamins (thiamin, riboflavin, nicotinic acid, pyridoxine, choline, biotin, folic acid, cyanocobalamin, inositol, vitamin- $\mathrm{B}_{6}$ and vitamin- $\mathrm{B}_{12}$ ) and vitamin $\mathrm{C}$. Fat soluble vitamins of meat including vitamin $A$, vitamin $D$ and vitamin $K$ also participate in the nutritional importance of meat [38].

Meat is a good source of five of the B-complex vitamins including thiamin, riboflavin, nicotinic acid, vitamin $B_{6}$ and vitamin $B_{12}$. It also contains pantothenic acid and biotin, but a poor source of folacin [39]. Vitamin content of various raw meats is illustrated in Table 6.

\begin{tabular}{lllllllll}
\hline Meat source & $\mathbf{F e}$ & $\mathbf{P}$ & $\mathbf{N a}$ & $\mathbf{C a}$ & $\mathbf{C u}$ & $\mathbf{M g}$ & $\mathbf{Z n}$ & $\mathbf{K}$ \\
\hline $\begin{array}{l}\text { Ox } \\
\text { (Kidney) }\end{array}$ & 5.6 & 231 & 182 & 9 & 0.5 & 16 & 1.8 & 232 \\
Ox & & & & & & & & \\
(Liver) & 7.1 & 362 & 80 & 6.1 & 2.4 & 19.2 & 4.1 & 321 \\
$\begin{array}{l}\text { Sheep (Kidney) } \\
\text { Sheep }\end{array}$ & 7.5 & 242 & 221 & 10.2 & 0.5 & 17.1 & 2.5 & 272 \\
(Liver) & 9.5 & 371 & 75 & 7.1 & 8.8 & 19.1 & 4.0 & 291 \\
$\begin{array}{l}\text { Pig } \\
\text { (Kidney) }\end{array}$ & 5.1 & 272 & 191 & 8.1 & 0.7 & 19.1 & 2.7 & 291 \\
$\begin{array}{l}\text { Pig } \\
\text { (Liver) }\end{array}$ & & & & & & & & \\
Brain & 21.2 & 372 & 88 & 6.2 & 2.8 & 21.3 & 7.0 & 319 \\
\hline
\end{tabular}

Table 5. Mineral content of offal tissues [22, 36]. 


\subsubsection{Water soluble vitamins}

\subsubsection{Thiamin}

It works along with other B-complex vitamins to carry out numerous chemical reactions required for the growth and maintenance of the human body. They are involved in the metabolic processes necessary for energy production to perform various body functions. Deficiency of thiamine could cause loss of appetite, fatigue, constipation, irritability and depression. Meat in general is a good source of thiamine with especial reference to fish which provides larger quantities of it as compared to other meat sources except pork.

\subsubsection{Riboflavin}

It is essential to release energy from the major food constituents like proteins, fats and carbohydrates. It helps in retaining good eye sight and healthy skin. It also aids in the absorption and utilization of iron. Moreover, it is required in the conversion process from tryptophan to niacin. Poultry meat, lamb and beef are considered among the good sources of riboflavin.

\subsubsection{Niacin}

Together with other B-vitamins, niacin functions in a variety of intracellular enzyme systems, including those involved in energy production. Its sources are meat, fish and poultry etc. Its deficiency causes the disease called as "pellagra" which is characterized by the rough or raw skin. Other problems include memory loss, vomiting and diarrhea.

\begin{tabular}{llllll}
\hline $\begin{array}{l}\text { Vitamin units/100 g } \\
\text { raw meat }\end{array}$ & Beef & Bacon & Mutton & Veal & Pork \\
\hline A (Inter. Unit.) & Trace & Trace & Trace & Trace & Trace \\
D (Inter. Unit.) & Trace & Trace & Trace & Trace & Trace \\
$B_{1}(\mathrm{mg})$ & 0.06 & 0.39 & 0.14 & 0.11 & 1.2 \\
$B_{2}(\mathrm{mg})$ & 0.21 & 0.16 & 0.24 & 0.26 & 0.21 \\
Nicotinic acid $(\mathrm{mg})$ & 5.1 & 1.6 & 4.99 & 7.1 & 5.2 \\
Pantothenic acid $(\mathrm{mg})$ & 0.5 & 0.4 & 0.6 & 0.5 & 0.5 \\
Biotin $(\mu \mathrm{\mu g})$ & 2 & 8 & 4 & 6 & 5 \\
Folic acid $(\mu \mathrm{g})$ & 9 & $\mathrm{Nil}$ & 2 & 6 & 2 \\
$\mathrm{~B}_{6}(\mathrm{mg})$ & 0.2 & 0.3 & 0.3 & 0.4 & 0.4 \\
$\mathrm{~B}_{12}(\mu \mathrm{gg})$ & 2 & $\mathrm{Nil}$ & 2 & $\mathrm{Nil}$ & 2 \\
$\mathrm{C}(\mathrm{mg})$ & $\mathrm{Nil}$ & $\mathrm{Nil}$ & $\mathrm{Nil}$ & $\mathrm{Nil}$ & $\mathrm{Nil}$ \\
\hline
\end{tabular}

Table 6. Vitamin content of various raw meats [31, 36]. 


\subsubsection{Vitamin $B_{6}$}

Vitamin $B_{6}$ plays a vital role in the functioning of approximately 100 enzymes that catalyze the essential chemical reactions in the human body. It helps in the synthesis of the neurotransmitters and important in the synthesis of heme iron i.e. a component of hemoglobin. Additionally, it also helps in the synthesis of niacin from tryptophan. Important meaty sources of vitamin$\mathrm{B}_{6}$ are fish, poultry and meat.

\subsubsection{Vitamin $B_{12}$}

This vitamin is important for the synthesis of deoxyribonucleic acid (DNA), which is a genecontaining component of cell's nucleus, vital for proper growth and development of the human body. Vitamin- $\mathrm{B}_{12}$ is found only in foods of animal origin; therefore, vegans (vegetarians who consume no animal products) might have been needed to supplement their diet with this vitamin. Individuals who have pernicious anemia (inability to absorb vitamin- $\mathrm{B}_{12}$ from food) and do not consume vitamin- $B_{12}$ can be treated successfully with injections of vitamin- $\mathrm{B}_{12}$. Liver, beef, lamb and pork are rich sources of this vitamin. Some other sources are oysters, fish, egg yolk and cheese.

\subsubsection{Loss of B complex vitamins during meat processing}

Vitamins present in the meat get lost during its processing by both methods of conventional heating and microwave heating especially in case of vitamin $B_{1}$ [40]. The retention of both the vitamins $B_{1}$ and $B_{2}$ from different kinds of the meat by conventional cooking is shown in the table. The loss of vitamin $B_{1}$ was mainly observed by leaching. These losses are about $15-40 \%$ by boiling, $40-50 \%$ by frying, 30-60\% through roasting, and 50-70\% on canning [40]. Other vitamins of $B$ complex family including $B_{6^{\prime}} B_{12}$ and pantothenic acid also exhibit same issues like $B_{1}$. Contrary to it, vitamin $\mathrm{A}$ has the ability to retain even at the temperature of $80^{\circ} \mathrm{C}$. Loss or retention of B complex vitamins during conventional and microwave cooking is illustrated in Table 7.

\begin{tabular}{lllll}
\hline $\begin{array}{l}\text { Meat } \\
\text { samples }\end{array}$ & $\begin{array}{l}\text { Cooking method } \\
\text { involved }\end{array}$ & $\begin{array}{l}\text { Cooking losses water } \\
\text { and fat (\% initial weight }\end{array}$ & $\begin{array}{l}\text { Vitamin } \mathbf{B}_{1} \text { retention } \\
\text { in meat and dripping } \\
(\% \text { initial) }\end{array}$ & $\begin{array}{l}\text { Internal temperature } \\
\left({ }^{\circ} \mathrm{C}\right)\end{array}$ \\
\hline Beef & Conventional & $19-20$ & $82-87$ & 62.5 \\
Beef & Microwave & $28-38$ & $70-80$ & 70.5 \\
Beef loaves & Conventional & 24.2 & 76.5 & 85.5 \\
Beef loaves & Microwave & 27.3 & 79 & 84.5 \\
Pork & Conventional & 34.1 & 80.3 & 85 \\
Pork & Microwave & 36.7 & 90.8 & 86 \\
Ham loaves & Conventional & 18.4 & 91.4 & 85 \\
Ham loaves & Microwave & 27.8 & 87.2 & 84 \\
\hline
\end{tabular}

Table 7. Comparison of cooking losses and vitamin $B_{1}$ retention in conventional and microwave cooking [31]. 


\begin{tabular}{llllllllll}
\hline Meat source & $\begin{array}{l}\mathbf{B}_{\mathbf{1}} \\
(\mathbf{m g})\end{array}$ & $\begin{array}{l}\mathbf{B}_{2} \\
(\mathbf{m g})\end{array}$ & $\begin{array}{l}\mathbf{B}_{3} \\
(\mathbf{m g})\end{array}$ & $\begin{array}{l}\mathbf{B}_{\mathbf{6}} \\
(\mu \mathrm{g})\end{array}$ & $\begin{array}{l}\mathbf{B}_{9} \\
(\mu \mathrm{g})\end{array}$ & $\begin{array}{l}\mathbf{B}_{\mathbf{1 2}} \\
(\mu \mathrm{g})\end{array}$ & $\begin{array}{l}\text { Vit. C } \\
(\mathbf{m g})\end{array}$ & $\begin{array}{l}\text { Vit. D } \\
(\mu \mathrm{g})\end{array}$ & $\begin{array}{l}\text { Vit. A } \\
(\mathrm{I} . U .)\end{array}$ \\
\hline Brain & 0.06 & 0.02 & 2.99 & 0.10 & 6.0 & 8.9 & 23.0 & Trace & Trace \\
Sheep's kidney & 0.5 & 1.9 & 8.4 & 0.32 & 31.0 & 54.9 & 6.9 & Nil & 99 \\
Ox's kidney & 0.38 & 2.2 & 6.1 & 0.33 & 77.2 & 31.2 & 10.1 & Nil & 150 \\
Pig 's kidney & 0.33 & 2.0 & 7.4 & 0.24 & 42.1 & 14.2 & 14.3 & Nil & 110 \\
Sheep's liver & 0.28 & 3.4 & 14.1 & 0.43 & 220 & 83 & 9.9 & 0.49 & 20,000 \\
Ox's liver & 0.22 & 3.2 & 13.5 & 0.84 & 330 & 109.7 & 23.0 & 1.14 & 17,000 \\
Pig 's liver & 0.32 & 3.1 & 14.7 & 0.69 & 110 & 24.8 & 13.2 & 1.14 & 10,000 \\
Sheep's lung & 0.13 & 0.5 & 4.8 & Nil & Nil & 4.8 & 31.2 & Nil & Nil \\
Ox's lung & 0.10 & 0.4 & 4.1 & Nil & Nil & 3.2 & 38.7 & Nil & Nil \\
Pig 's lung & 0.10 & 0.3 & 3.3 & Nil & Nil & Nil & 13.1 & Nil & Nil \\
\hline
\end{tabular}

Table 8. Vitamin contents (units/100 g raw tissue) of various offal tissues [22, 36].

\subsubsection{Fat soluble vitamins}

Vitamin A is a fat-soluble vitamin necessary for the maintenance of healthy tissues and for maintaining the normal vision and eyesight. Green and yellow vegetables provide most of the vitamin A and it occurs in the form of carotene (a precursor which the body converts to vitamin A). Milk and margarine are often fortified with vitamin A. Liver is suggested as the greatest single food source of vitamin A. It is also a good source of the other fat-soluble vitamins such as vitamin D and vitamin K [41]. Vitamin contents (water and fat soluble) of various offal organs are shown in Table 8.

\section{Conclusion}

This chapter concludes that meat and meat products have significant role in fulfillment and maintenance of human health. Studies indicated that strong nutritional composition (fats, proteins and carbohydrates) with minerals, vitamins and other functional compounds have a preventive role against major and minor nutrients deficiency diseases. This food material must be included as important proportion in balanced diet to meet the required health benefits. Proteins and amino acids are beneficial for growth and building of muscles in humans. Owing to the fats and fatty acid profile composition of meat, there is a point to be concerned about the consumption of meat because of the presence of saturated fats that cause coronary heart diseases and elevated cholesterol level if taken in higher than normal amount. Thus, intake of meat in balanced proportion must be according to the prescription of nutritionist and health practitioners. Additionally, minerals and vitamins including zinc, iron, selenium, sodium, copper, magnesium, calcium, potassium, phosphorus and vitamin A along with ample amount of B complex vitamins are considered as important constituents of meat, respectively, that are beneficial for overall human health stratum. 


\section{Acknowledgements}

We would like to acknowledge that Government College University Faisalabad and its IT department provided us kind permission to use digital library and access to research data.

\section{Conflict of interest}

The authors declare no conflict of interest.

\section{Author details}

Rabia Shabir Ahmad*, Ali Imran and Muhammad Bilal Hussain

*Address all correspondence to: rabiaahmad@gcuf.edu.pk

Institute of Home and Food Sciences, Government College University Faisalabad, Pakistan

\section{References}

[1] Eze NM, Maduabum FO, Onyeke NG, Anyaegunam NJ, Ayogu CA, Ezeanwu BA, Eseadi C. Awareness of food nutritive value and eating practices among Nigerian bank workers: Implications for nutritional counseling and education. Medicine. 2017 Mar;96(10)

[2] Kihara J, Sileshi GW, Nziguheba G, Kinyua M, Zingore S, Sommer R. Application of secondary nutrients and micronutrients increases crop yields in sub-Saharan Africa. Agronomy for Sustainable Development. 2017 Aug 1;37(4):25

[3] De Smet S, Vossen E. Meat: The balance between nutrition and health. A review. Meat Science. 2016 Oct 1;120:145-156

[4] Pereira PM, Vicente AF. Meat nutritional composition and nutritive role in the human diet. Meat Science. 2013 Mar 1;93(3):586-592

[5] Hocquette JF, Gondret F, Baéza E, Médale F, Jurie C, Pethick DW. Intramuscular fat content in meat-producing animals: Development, genetic and nutritional control, and identification of putative markers. Animal. 2010 Feb;4(2):303-319

[6] Sinclair A, Mann N, O'Connell S. The Nutrient Composition of Australian Beef and Lamb. RMIT: Melbourne; 1999

[7] Williams P. Nutritional composition of red meat. Nutrition and Dietetics. 2007 Sep $1 ; 64(s 4)$ 
[8] Kamruzzaman M, Makino Y, Oshita S. Parsimonious model development for real-time monitoring of moisture in red meat using hyperspectral imaging. Food Chemistry. 2016 Apr 1;196:1084-1091

[9] Jensen J, Rustad PI, Kolnes AJ, Lai YC. The role of skeletal muscle glycogen breakdown for regulation of insulin sensitivity by exercise. Frontiers in Physiology. 2011 Dec 30;2:112

[10] Adzitey F, Nurul H. Pale soft exudative (PSE) and dark firm dry (DFD) meats: Causes and measures to reduce these incidences-a mini review. International Food Research Journal. 2011 Feb 1;18(1)

[11] Karunanayaka DS, Jayasena DD, Jo C. Prevalence of pale, soft, and exudative (PSE) condition in chicken meat used for commercial meat processing and its effect on roasted chicken breast. Journal of Animal Science and Technology. 2016 Dec;58(1):27

[12] Marangoni F, Corsello G, Cricelli C, Ferrara N, Ghiselli A, Lucchin L, Poli A. Role of poultry meat in a balanced diet aimed at maintaining health and wellbeing: An Italian consensus document. Food and Nutrition Research. 2015 Jan 1;59(1):27606

[13] Barron-Hoyos JM, Archuleta AR, del Refugio Falcon-Villa M, Canett-Romero R, CincoMoroyoqui FJ, Romero-Barancini AL, Rueda-Puente EO. Protein quality evaluation of animal food proteins by in-vitro methodologies. Food and Nutrition. 2013;4:376-384

[14] Schweigert BS, Payne BJ. A Summary of the Nutrient Content of Meat. Bulletin No. 30, American. Chicago: Meat Inst. Foundation; 1956

[15] Mahan DC, Shields RG Jr. Essential and nonessential amino acid composition of pigs from birth to 145 kilograms of body weight, and comparison to other studies. Journal of Animal Science. 1998;76(2):513-521

[16] Sakomura NK, Ekmay RD, Mei SJ, Coon CN. Lysine, methionine, phenylalanine, arginine, valine, isoleucine, leucine, and threonine maintenance requirements of broiler breeders. Poultry Science. 2015 Oct 23;94(11):2715-2721

[17] Soladoye OP, Juárez ML, Aalhus JL, Shand P, Estévez M. Protein oxidation in processed meat: Mechanisms and potential implications on human health. Comprehensive Reviews in Food Science and Food Safety. 2015 Mar 1;14(2):106-122

[18] Yu TY, Morton JD, Clerens S, Dyer JM. Cooking-induced protein modifications in meat. Comprehensive Reviews in Food Science and Food Safety. 2017 Jan 1;16(1):141-159

[19] Wood JD, Enser M, Fisher AV, Nute GR, Sheard PR, Richardson RI, Hughes SI, Whittington FM. Fat deposition, fatty acid composition and meat quality: A review. Meat Science. 2008 Apr 1;78(4):343-358

[20] Grunert KG, Bredahl L, Brunsø K. Consumer perception of meat quality and implications for product development in the meat sector $-\mathrm{A}$ review. Meat Science. $2004 \mathrm{Feb}$ $1 ; 66(2): 259-272$

[21] Woods VB, Fearon AM. Dietary sources of unsaturated fatty acids for animals and their transfer into meat, milk and eggs: A review. Livestock Science. 2009 Dec 1;126(1):1-20 
[22] Paul A, Southgate DA. New food tables. Nutrition and Food Science. 1978 Jan 1;78(1):2-3

[23] Williams P, Droulez V, Levy G, Stobaus T. Composition of Australian red meat 2002. 3. Nutrient profile. Food Aust. 2007;59:331-341

[24] Droulez V, Williams PG, Levy G, Stobaus T, Sinclair A. Composition of Australian red meat 2002. 2. Fatty acid profile. Food Aust. 2006;58:335-341

[25] Food standards Australia New Zealand. Nuttab 2006. Online Database of the Nutritional Composition of Australian Foods. Canberra: Fsanz, 2006

[26] Wood JD, Richardson RI, Nute GR, Fisher AV, Campo MM, Kasapidou E, Sheard PR, Enser M. Effects of fatty acids on meat quality: A review. Meat Science. 2004 Jan $1 ; 66(1): 21-32$

[27] Aranceta J, Pérez-Rodrigo C. Recommended dietary reference intakes, nutritional goals and dietary guidelines for fat and fatty acids: A systematic review. British Journal of Nutrition. 2012 Jun;107(S2):S8-S22

[28] Andersen HJ, Oksbjerg N, Young JF, Therkildsen M. Feeding and meat quality-a future approach. Meat Science. 2005 Jul 1;70(3):543-554

[29] Lehnen TE, da Silva MR, Camacho A, Marcadenti A, Lehnen AM. A review on effects of conjugated linoleic fatty acid (CLA) upon body composition and energetic metabolism. Journal of the International Society of Sports Nutrition. 2015 Dec; 12(1):36

[30] Soetan KO, Olaiya CO, Oyewole OE. The importance of mineral elements for humans, domestic animals and plants-a review. African Journal of Food Science. 2010 May 31;4(5):200-222

[31] McCance RA, Widdowson EM. The Composition of Foods. 3rd ed. London: Her Majesty's Stationery Office; 1960

[32] Chan W, Brown J, Lee S, Buss DHM. Poultry and Game. Fifth Supplement to McCance \& Widdowson's the Composition of Foods. London: The Royal Society of Chemistry and the Ministry of Agriculture Fisheries and Food; 1995

[33] Lozoff B, Georgieff MK. Iron deficiency and brain development. In Seminars in Pediatric Neurology 2006 Sep 1. Elsevier. 13(3):158-165

[34] Hurrell R, Egli I. Iron bioavailability and dietary reference values. The American Journal of Clinical Nutrition. 2010 Mar 3;91(5):1461S-1467S

[35] Simpson RJ, McKie AT. Regulation of intestinal iron absorption: The mucosa takes control? Cell Metabolism. 2009 Aug 6;10(2):84-87

[36] Williams P. Nutritional composition of red meat. Nutrition \& Dietetics. 2007;64(Suppl. 4):S113-S119. DOI: 10.1111/j.1747-0080.2007.00197.x

[37] Huskisson E, Maggini S, Ruf M. The role of vitamins and minerals in energy metabolism and well-being. Journal of International Medical Research. 2007 May;35(3):277-289 
[38] Ali Hassan A, Sandanger TM, Brustad M. Selected vitamins and essential elements in meat from semi-domesticated reindeer (Rangifer tarandus tarandus L.) in mid-and northern Norway: Geographical variations and effect of animal population density. Nutrients. 2012 Jul 10;4(7):724-739

[39] Wyness L, Weichselbaum E, O'connor A, Williams EB, Benelam B, Riley H, Stanner S. Red meat in the diet: An update. Nutrition Bulletin. 2011 Mar 1;36(1):34-77

[40] Pathare PB, Roskilly AP. Quality and energy evaluation in meat cooking. Food Engineering Reviews. 2016 Dec 1;8(4):435-447

[41] Ravisankar P, Reddy AA, Nagalakshmi B, Koushik OS, Kumar BV, Anvith PS. The comprehensive review on fat soluble vitamins. IOSR Journal of Pharmacy. 2015;5(11):12-28 


\title{
Edited by Muhammad Sajid Arshad
}

\begin{abstract}
Meat holds an important position in human nutrition. Although protein from this source has lower biological value than egg albumin, it is an exclusive source of heme iron and vitamins and minerals. Fat content and fatty acid profile from this source are a constant matter of concern. Though currently meat utilization is linked with an array of maladies, including atherosclerosis, leukemia, and diabetes, meat has a noteworthy role not only for safeguarding proper development and health, but also in human wellbeing. Enormous scientific investigations have proved that consuming meat has had a beneficial role in cranial/dental and gastrointestinal tract morphologic changes, human upright stance, reproductive attributes, extended lifespan, and maybe most prominently, in brain and cognitive development.
\end{abstract}

\section{IntechOpen}

